sh. 19.160.

$464 x$ thth 
S.HECUNIVERSIT)

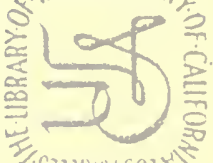

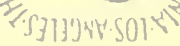

MEE LIBRARYOF.
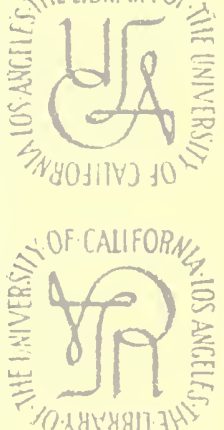

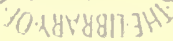

\&HE UVIVERSIr,
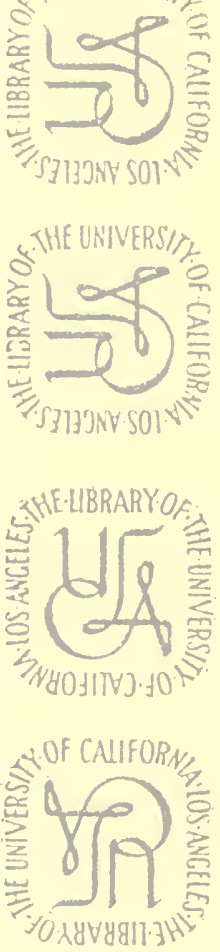

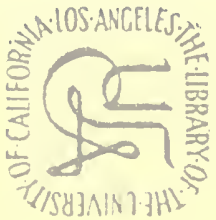

.
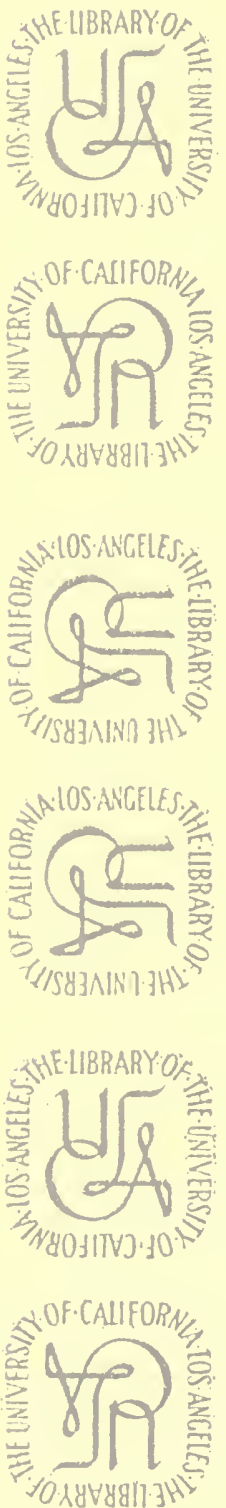
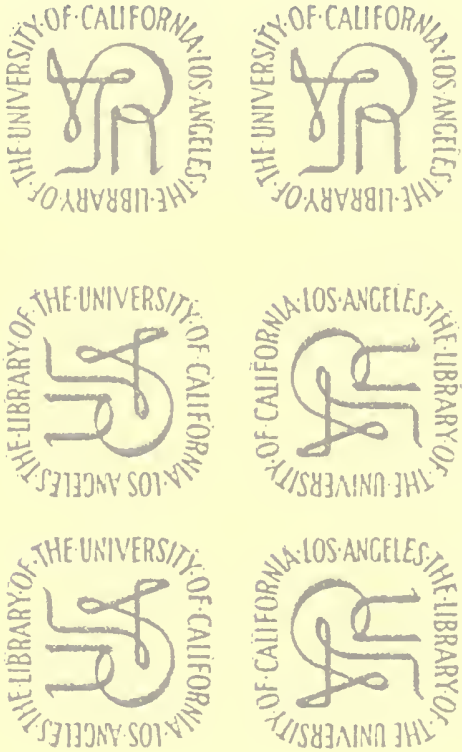

NHELIBRARYOF.
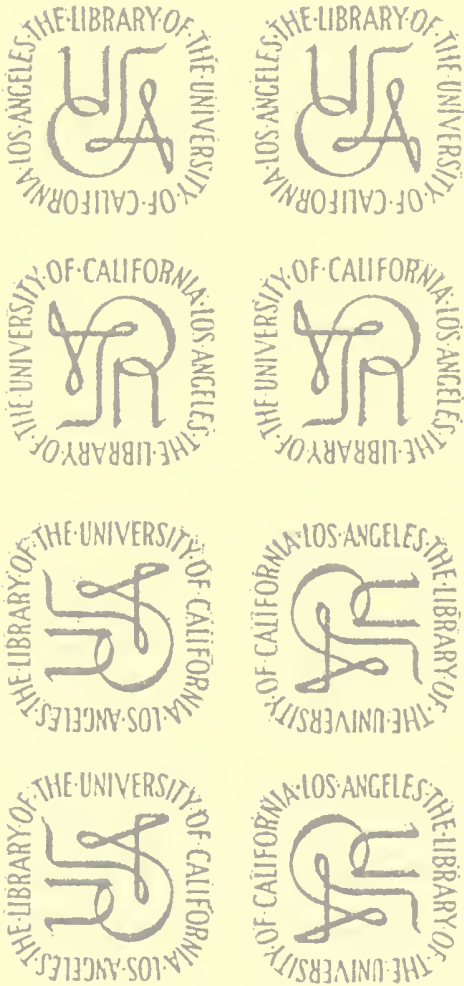



\section{STATISTICAL SURVEY}

\section{OF THE \\ COUNTY OF TYRONE, \\ พIT H \\ 4}

OBSERVATIONS

ON

THE MEANS OF IMPROVEMENT;

DRAWN UP IN THE YEARS 1801, AND 1802,

GOR THE CONSIDERATION, AND UNDER THE DIRECTION

OF

The Dublin Sacietp.
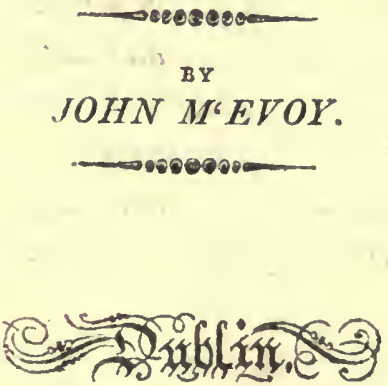

PRINTED BY GRAISBERRY AND CAMPBEI.L, NO. IO, BACK-LANE. 


\section{TO THE READER.}

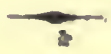

This REPORT is at present printed and circulated for the purpose merely of procuring further information, respecting the state and lousbandry of this district, and of cnabling every one interested in the welfare of this country, to exumine it fully, and contribute bis mite to its improvenent.

The Society do not deem themselves pledged to any opinion given by the Autbor of this Survey; and they desire, that notbing contained in it be considered as their sentiments; they bave only published it, as the report of the gentleman, whose name is affixed, and they publish it for the comments and obscrvations of all persons, wubich they entreat to be given freely, and without reserve.

It is therefore requested, that the observations on reading this work may be returned to the Dublin Society, as soon as may be convenient, and which suill meet with the fullest attention in a future edition. 


\section{$D A$ \\ 990 \\ T9Mis \\ DEDICATION.}

TO THE RIGHT HON.

LORD VISCOUNT MOUNTJOY.

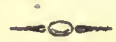

MY LORD,

WERE your Lordhip's noble father alive, gratitude and duty would have required that this, my firft effay, thould have been offered to his protection. He would naturally have been looked to, as the fuitable patron for an Agricultural Survey of the County of 'Tyrone, to which his improvements were fo ornamental, and in which his character was fo highly refpected.

In full confidence, that his virtues will ftill afcompany his fortune, and that what his tafte began, your Lordfhip will bring to perfection, 
I dedicate this imperfect tribute of my refpect to your Lordfhip's patronage, and have the honour to fubfcribe myfelf,

With great deference,

Your Lordhip's moft devoted

Humble fervant,

IOIIN M'EYOI'.

RASH, NEAR OMAGH,

1502 . 


\section{PRELIMINARY OBSERVATIONS.}

A complete Agricultural Survey of a county of fuch extent, opulence, and variety, as the county of Tyrone, would require a writer of much general information and fcientific refearch. The only qualifications, which the writer of the prefent effay can pretend to have brought to his fubject, are, an acquaintance-with agricultural concerns from his earlieft age, and a local knowledge of the county of Tyrone, obtained from a refidence in it for many years.

The author had originally intended to have introduced in this work fome fketch of the procefs of the linen manufacture, but this has been anticipated in the Survey of the County of Monaghan, where the foil and management are nearly the fame as in this county.

A botanical arrangement of the indigenous plants has been laid afide, as a matter of too much magnitude for a work of this kind; but, 
at fome future period, the author hopes to lay it before the public in a feparate work.

For many valuable hints, as to the mode of drawing up the Survey, and fuggeftions of ufeful and important topics, the author returns his grateful acknowledgments to the Right Hon. John Fofter.

What has been faid refpecting Lord Mountjoy's extenfive demefne and plantations at $\mathrm{Rah}$, in various parts of this work, it has been fince thought expedient to bring under one general head, in the form of an Appendix, that the reader, whore chief object may be that of ornamental improvements, may have, without interruption, a connected and perfpicuous view of the whole. 


\section{SUGGESTIONS OF ENQUIRY}

ZOR GENTLEMEN WHO SHALL UNDERTAKE THE EORMING OE AGRICULTURAL SURVEYS.

CEOGRAPHICAL STATE AND CIRCUMSTANCIO.

Situation and Extent,

Divifions,

Climate,

Soil and Surface,

Minerals,

Water.

AGRICUITURE.

Mode of culture,

Extent of it, and of each fpecies of grain fowed,

Courfe of crops,

Ufe of oxen-how harneffed,

Nature and ufe of implements of hußbandry,

Markets for grain,

Ufe of green food in winter. 


\section{PASTURE.}

Nature of it,

Breed of cattle - how far improved, -how far capable of further improvement,

Markets or Fairs for them,

General prices,

Modes of feeding - how far houfed in winter,

Natural graffes,

Artificial grafles,

Mode of hay-making,

Dairies, their produce,

Prices of hides, tallow, wool, and quantity fold.

Their fize,

FARMS.

Farm houfes and offices,

Mode of repairing them, whether by landlord or tenant,

Nature of tenures,

General Itate of leafes, of particular claufes therein,

Taxes or Ceffes paid by tenants,

Proportion of working horfes or bullocks, to the fize of farms,

General fize of fields, or enclofures,

Nature of fences,

Mode of hedge-rows, and keeping hedges,

Mode of draining,

Nature of manures. 


\section{OF ENQUIRY.}

\section{GENERAL SUBJECTS.}

Population,

Number and fize of villages and towns,

Habitation, fuel, food and cloathing of the lower rank-their general colt,

Prices of wages, labour, and provifions,

State of tithe, its general amount on each article-what arti-

cles are exempt, and what charged by modus,

Ufe of beer and fpirits-whether either or which is increafing,

State of roads, bridges, \&c.

- of navigations and navigable rivers,

— of fitheries,

State of education, fchools, and charitable inftitutions,

- of abfentee and refident proprietors,

_ of circulation of money or paper,

- of farming or agricultural focieties,

- of manufactures, whether increafing,

- of encouragement to them, and the peculiar aptnefs of the fituation for their extenfion,

- of mills of every kind,

- of plantations and planting,

- of the effects of the encouragement heretofore given to them by the Society, particularifed in the lift annexed.

- of any improvements which may occur for future encouragement, and particularly for the prefervation of the trees, when planted,

- of nurferies within the county aad extent of fales, 
Price of timber and ftate of it, in the county,

Quantity of bog and walte ground,

Poffbility and means of improving it,

Obftacles to it and beft means of removing them,

Habits of induftry, or want of induftry among the people,

The ufe of the Englith language, whether general, or how far increafing,

Account of towers, caftles, monafteries, ancient buildings, or places remarkable for any hiftorical cvent,

Churches-refident clergy, glebes and glebe houfes,

Whether the county has been afually furveyed, when and whether the furvey is publined,

Weights and meafures, liquid or dry-in what inftances are weights affigned for meafures-or vice verfâ,

The weight or meafure, by which grain, flour, potatoes, butter, Ec. are fold. 


\title{
CONTENTS.
}

\author{
CHAP. I.
}

" GEOGRAPHICAL STATE AND CIRCUMSTANCE.

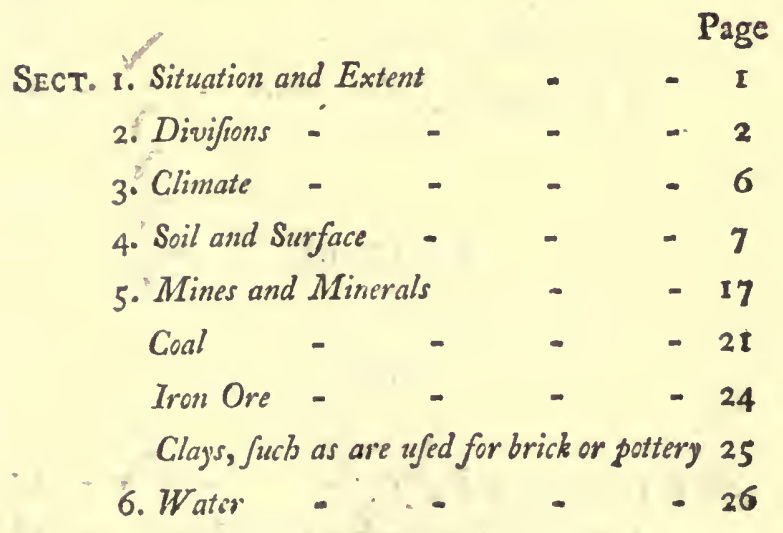

CHAP. 


\section{AGRICULTURE.}

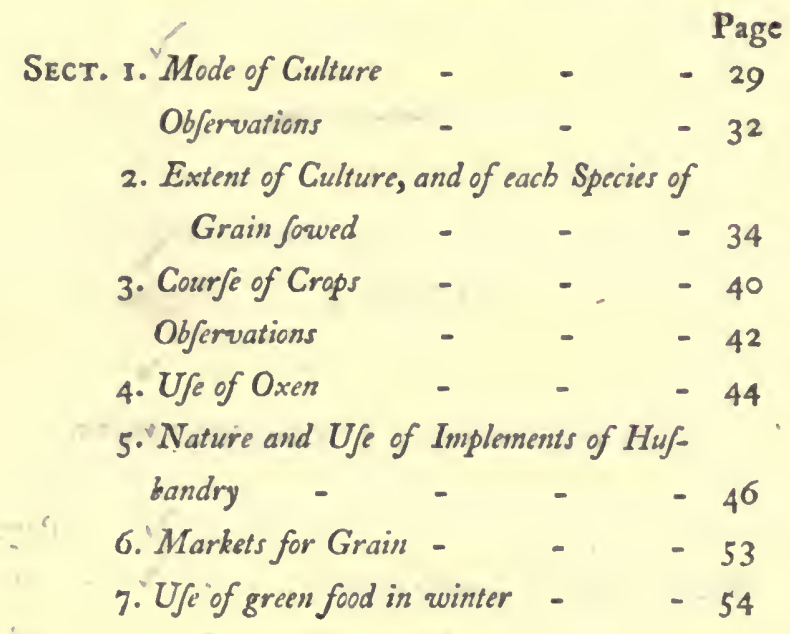

CHAP. III.

PASTURE.

SEct. 1. Nature of Pafure -

2. Breed of Cattle-bow far improved - $5^{8}$ bow far capable of further improvement - $\quad$ - $6 \mathrm{I}$ 3. Markets and Fairs for Cattle , - ib. Sect. 
CONTENTS.

Sвст. 4. General Prices

- 5. Mode of feeding Cattle . - _ - 64

Cattie, bow far houfed in winter $\quad-67$

6: Natural Grafes - - - - $\quad$ - 70

7. Artificial Grafjes - _ $\quad$ - 74

8. Mode of Hay-making - - $\quad 75$

Objervations $\quad-\quad-\quad-\quad 79$

9.'Dairies-tbeir produce _ - $\quad$ - $8 \mathrm{I}$

Obfervations - $\quad$ - $\quad-\quad 82$

10. Prices of Hides, Tallow, Wool, and

2uantity fold - - $\quad-85$

CHAP. IV.

FARMS。

SECT. 1. Size of Farms - - - $\quad 90$

2. Farm-boufes and Offices - - 95

Mode of repairing Houfes and Offices, whether by Landlord or Tenant - 97

3. Nature of Tenures - - $\quad 99$

4. General State of Leajes - _ $\quad 100$

- Of particular Claujes in Leajes - 102

5." Taxes or Ceffes paid by Tenants - 104

6.'Proportion of working Horjes or Bullocks, to the fize of Farms

- 105

Sect. 


\section{SECT. 7. General fize of Fields and Enclofures 106 \\ 8. Nature of Fences - _ _ - 107 \\ Mode of bedge-rows, and keeping bedges 109 \\ 9. Nature of Manures - - - III \\ 10. Mode of Draining _ _ - II5}

\section{CHAP. V.}

POLITICAL ECONOMY.

SECT. 1. Roads and Bridges

$-118$

2. State of Navigations and Navigable

Rivers

3. State of Fijperies -

4. State of Manufactures
- I3I

- 134

- 135

Of encouragement to them, and the peculiar aptnefs of the fotuation for their extenfion.

- 137

Lift of Bleach-greens

- $13^{8}$

5. Population

- 142 


\section{CHAP VI.}

\section{RURAL ECONOMY.}

SEcr. I. Prices of Wages, Labour, and Provifions 143

2. Habitation, fuel, food, and clotbing of the lower rank; their general cof 146

\section{CHAP. VII.}

\section{GENERAL SUBJECTS,}

SEct. I. Number and Size of Villages $E$ Toruns

2. State of Tithe, its general amount on each Article- what Articles are exempt, and what charged by modus - 161

3. Ufe of Beer and Spirits-whether either,

$$
\text { or which is encreafing . } \quad-\quad-162
$$

4. State of Education, Schools, and Charitable Infitutions - $=-163$,

5. Of abjentee and refident Proprictors - 167 6. Of Circulation of Money or Paper - I 7 I

7. Of Farming or Agricultural Socisties ib.

3. Of Mills of every kind _ - $\quad$ - 172 
Secr. 9. Of Plantations and Planting - $\quad$ - 174

Of the Effects of the Encouragement heretofore given to Planting by the Socicty, particularized in the Lift annexed - 178

Of any improvements, which may occur for future encouragement, and particularly for the prefervation of Trees when planted

$-181$

10: Of Nurferies within the County, and

Extent of Sales $\quad$ - $\quad 183$

11. Prices of Timber, and State of it in the

County - - - - $\quad-187$

12. 2uantity of Bog and Wafse Ground 189 Poflibility and means of improving it - 190 Obfacles to improvement, and the beft mans of reanoving them - $\quad$ - 197

3. Habits of induftry, or avant of induffry among the Peop.e $\quad$ - $\quad$ - $\quad$ - 199

14. The ufe of the Eng $\ddot{i}$ s Language-ubether general, or bow far increasing 201 35. Aicount of Towvers, Caffies, Monafteries, Ancicnt buildings, or places remarkab.e for uny biforical event - 202

36. Churches - Refident C'ergy-Giebes, and Giebe-boufes - - 205 
SEcr. 17. Whetber the County bas been actually furveyed--wowen and whetber the

Survey is publifbed - - - 206

18. Weigbts and Meafures, liquid or dry-

in what infances are Weights af-

figned for Meafures-or vice verfa ib.

19. The Weight or Meafure, by which

Grain, Flour, Potatoes, Butter, Eंc.

are fold - - . - 207

\section{APPENDIX.}

An Account of Lord Mountjoy's Improvements at Rafh, and the manner of carrying them into execution, from the year 1778 , to the prefent time.

SEcT. I. Seminary and Nurfery - - - 1

2. The general Plan of fettling the great outlines of the Demefne and its appendages - - - - 4

3. Modes of enclofing - - - - 7 Louth fence $\quad \therefore \quad-\quad-\quad-11$ Sunk fince $\quad-. . \quad-\quad-17$

Drains as Fences in baggy and fruanipy fituations - - - -22 l.iving 
Living Fences without a gripe or

$$
\text { trench - - - . - - } 24
$$

Temporary dead Fences, made principally of Scotch fir, cut away at the fize of eight or ten feet, or when it begins to injure plants of more value - - 31

Common paling of poft and rail, feepburdles, Ec. - • - - 34

4. Preparation of the Soils for planting 35

5. An acconnt of the management of an

Oak wood, wubich had been for many years on the decline, prior to the year 1792, - - - - - 52

6. Of the advantage of fowing potatoes, as a preparative to allift the Speedy growth of Plantations, and alfo, for the mo/t effectual mode of laying down bad lands to the greatef perfection - 57

7. Adcfcription of the management of the banks of the river at $K a f b$, fo far as it accompanies the demefne - $\quad-61$

8. An Account of $\mathcal{T}_{\mathrm{n} k \mathrm{k}}$, or Piece-zuork, together with a comparifon belween it and common Day Labour; with forne remarks on labouring Tools and Implements - - - 74 
Sect. 9. Manner of training up Boys, fo as to become ufeful, Aeady Labourers, with a number of ways to employ them to the bef advantage the year round. Alfo, feveral Modes, by which old Men, when partly paft their labour, may be applied to advantage to themfelves and their Employers - $\quad$ - 81 Obfervations with refpect to old Men and their families-the manner of employing them-zuith remarks on an bo/pital intended to be erected for their reception - - - - 92 


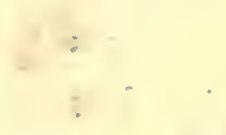

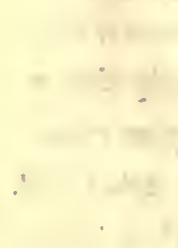

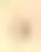

, 


\title{
STATISTICAL SURVEY
}

\author{
OF THE
}

\section{COUNTY OF TYRONE.}

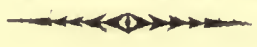

CHAP. I.

CEOGRAPHICAL STATE AND CIRCUMSTANCES."

SEcT. 1. Situation and Extent.

THE county of Tyrone is inland, being bounded by the county of Donegal on the north, and northweft; by the county of Londonderry, on the north, and north-eaft; by part of Loughneagh, and the county of Armagh, on the eaft; and by the counties of Monaghan and Fermanagh, on the fouth, and fouth-wett.

The county is very irregular, and much pointed and indented in its circumference. The greatef extent from north to fouth is from Donnelong, on the borders of the river Foyle, to Slieve-Beaygh mountain, on the borders of the county of Monaghan, being an extent of 33 miles; in Englin meafure- 
ment 42 miles. The greateft length from eaft to weft is, from the borders of Loughneagh, in the parin of Arboe, in the barony of Dungannon, to the extremity of the parifh of Farmonomungan, joining the counties of Donegal and Fermanagh, being in extent 43 miles; in Englin meafurement 54.8 miles. Meffrs. MrCrea's map of the county, made out in 1774,1775 , and 1776 , and Dr. Beaufort's memoirs agree perfectly with the above ftatement.

According to Dr. Beaufort's ftatement, the accuracy of which we have no, reafon to fufpect, the county contains 467,700 acres, and, of courfe, 724 fquare miles; in Englin meafurement 751,387 acres, being cqual to $\mathrm{I}_{1} 6_{3}$ fquare miles.

\section{SECT. 2. Divifisns.}

THE principal divifions are into baronies, namely; Barony of Strabane, to the north.

of Dungannon, to the eaft.

- of Clogher; to the fouth.

- in of Omagh, partly to the welt; but a large portion of it lies between the baronies of Strabane and Clogher, and meets the barony of Dungaunon. on the eaft. 


\section{OF THE COUNTY OF TYRONE.}

The above baronies are divided into parifhes as follows.

The barony of Strabane contains, win

I. Donaghedy.

2. Leckpatrick.

3. Caamus.

4. Urney; a fmall part in Donegal.

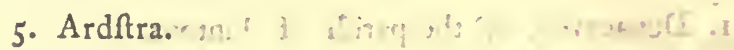

6. Upper Bodony.

7. Lower, do.

8. Cappagh.

9. Cumber; only a fmall part of this in the county.

The barony of Dungaimon contains,

I. Liffon, partly in the county Derry.

2. Kildrefs.

3. Derrylorne.

4. Defertcreat. and in, .......

5. Artray.

6. Ballinderry, partly in the county Derry.

7. Arboe:

8. Ballyclog.

9. Donaghendry.

ı. Clannoe.

II. Tullynifkal, V.

12. Drumglafs. 
13. Killymon.

14. Clonfeckle.

15. Pomeroy.

16. Donaghmore.

17. Killißhill.

18. Aughaloo.

\section{The barony of Clogber contains,}

1. Donacavey, or the parifh of Fintona.

2. Clogher.

3. Errigle-Keeran.

4. - Frough, V. partly in the county Monaghan.

5. Aghalurcher, partly in Fermanagh.

The barony of Omagh contains,

I. Earmonmagnírk.

2. Clougherny.

3. Drfomragh, or parin of Omagh.

4. Dromore.

5. Killkeery.

6. Longfield, lately divided into two livings. T $7 \cdot \chi^{\text {armonomuñgan. }}$

\section{Total number of parifbes.}

Barony of Strabane. 9 parifhes.

of Dungannon. 18 
Barony of Clogher. - of Omagh.

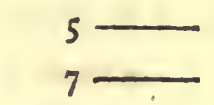

39 in the whole.

There are only 35 parimes, properly within the county, as only a fmall portion of the remaining four parimes are marked within the limits of the map of the county.

Except the parih of Tullynifkal, and the parih of Errigle-Frough, (both marked V. to denote a vicarage) the whole of the parifhes are rectories.

Ecclifrafical divifion.

Belonging to the dipcefe of Armagh, there are, 160,500 acres.

20 parithes.

19 benefices.

20 churches.

I3 glebe-houfes.

6 glebes, wanting glebe-houfes.

Belonging to the diocefe of Derry, there are, 233, 100 acres,

11 parihes.

11 benefices.

13 churches.

\& 3

9 glebe- 
9 glebc-houfes.

2 glebes, wanting glebe-houfes.

Bclonging to the diocefe of Clogher, there are, 68,000 acres.

- 4 parifhes.

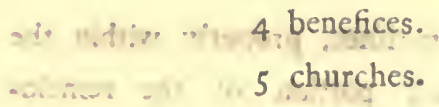

$\therefore$ ict $\therefore 2$ glebe-houfes.

2 glebes, wanting glebe-houfes.

The total of acres, in the ecclefiaftical diftricts of the county, appear to be 463,700 , being: 4000 acres lefs than the grofs amount of 467,700 , which 4000 , I take for granted, are abbey-land, or fuch lands, as are not fubject to tythes.

SECT. 3. Climate.

oy $81=00$. $\therefore 9=01$

THE latitude of a place does not always determine the climate; fo with this county, whofe main latitude is about $54 \frac{x}{2}$.

The great variety of foil and furface, throughout the county, caufes a great variation in the climate. Wefterly winds are molt prevalent the year round; hence follows the great humidity of our air, from being fituated fo near the Atlantic Ocean.

Our autumns are generally very wet, and unfavourable to the faving of crops of hay and corn. November is fometimes a favourable month.

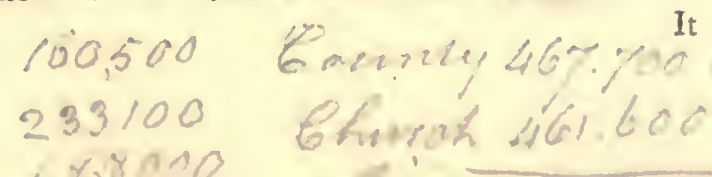




\section{OF THE COUNTY OF TYRONE.}

- It is the inconiftancy of the feafon's we have moft to guard againf; ; either extremes are never known to be intolerable.

The times of common occurrences in hubandry are, in a great meafure, determined by the climate. Oats are fown from the middle of March to the firft of May; barley during the whole month of May; flax-feed about the fame time. The hay' harveft, let the weather be never fo favourable, is genesally kept too late;

\section{SECT. 4. Soil and Surface.}

IT would be found an endlefs talk to enumerate the great variety of foils and furfaces within the county; the following fketch may, however, be depended upon.

The mountainy parts are generally Shallow, wet, and four ; in other parts dry, hurky, and peaty, the depth feldom exceeding fix inches. In fome places the fubftratum is tenacious, and hence we find the tops and fides of mountains generally wet and fpongy. In other parts, the fabrtratum is a black, folid bog, which is equally as tenacious as ftrong clay foil, and of courfe prevents the water from finking, by which means the furface is equally as bad 
bad as in the former cafe. But where the fubftratum is open rock, gravel, or any other porous body, through which the water may readily pafs, the furface is always dry and wholefome, and very well calculated for young ftock in fummer.: Mountains of the latter defcription are. always valuable to the owners, as they get a better price for feeding the ftock, which are fent to them generally in May, than thofe polfeffed of land of the two firf defcriptions; when the wet mountain lets only at five or fix hillings a fum*, the dry mountain clains ten hillings, and fometimes more.

Soils of the foregoing defcriptions are peculiar to the baronies of Strabane and Omagh; the baronies of Dungannon and Clogher are, generally fpeaking, of as good a quality of land, as perhaps any in the kingdom. A large tract of the weft parts of the barony of Dungannon, and of the north part of the barony of Clogher, may be ranked with the mountainy parts of the baronies of Strabane and Omagh.

The

* A phrafe moft commonly ufed in this county; a cow three years old is a fum; a two year old and one yearlung a fum; three yearlings a fum; a horfe is in fome parts a fum and a quarter, but is moft commonly a fum. A fum, bead collop, and ball, are fyponimous, accordipg to different countries. 
The furface of the whole county is wonderfully diverfified, hill and vale being the prevailing character.

The mountains of the greateft magnitude are in the barony of Strabane. The valt chains of the Munterloney mountains, ftretching into the county of Derrys are the moft confiderable; Mullaghcairn,- or Cairntogher, with Beffy Bell, and Mary Gray, and many others are very confiderable. Mullaghcairn is the higheft mountain in the courty, which I have proved; the next to it is Knockfowel, part of which is in the county of Derry. To the above may be added the mountains. of Ballygawley, on the weft of the barony of Dungannon, and Morley on the weft of the barony of Clogher.

In order to give the reader a more comprehenfive view of the foil and furface of the county, I thall fet down Omagh, the affize town, as a common centre; and proceed with the principal roads, throughout the county, to the extremities of it. But firft, I thall take a circular courfe, which will include part of the barony of Omagh, the whole of the barony of Clogher, and more than two parts of the barony of Dungannon. In the different excurfions, the crops ufually followed thall be remarked, which will, in fome meafure, give an idea of the qquality of the foil. 
Between Omagh and Dromore, diffance about feven, miles, the lands are, in general, light and gentle, very much undulated. In many parts the foil inclines. to a reddin colour, a great indication of fertility. Potatoes, flax, and oats, are the prin. cipal crops; in fome fpots barley; about the town of Dromore, the foil is not calculated for the latter. Limeftone is fcarce; but as , far as lime has been tried, it has been found to anfwer extremely well. Vaft quantities of afhes are made from the peaty foils, which are in this direction tolerably plenty, though the bogs are not, numerous or extenfive.

Limefone is not, found nearer to Dromore than the parifh of Longfield, which abounds in that atticle, but the want of good roads renders it precarious, and of courfe very expenfive.

From Dromore to Fintona, diftance abont five miles, light foil; ; appears extremely well calculated for Mreep, as the fubfratum is in general fand and gravel, which, of courfe, render the furface found and wholefome. Crops; potatoes, oats, and flax, or rather potatoes, flax, and oats in rotation, becaufe in few fituations, in this courfe, flax will not anfwer, unlefs fown immediately after potatocs, which is almoft univerfaliy the cafe is their mountainy foils. Two crops of oats in fuch fituations are ufually taken off after flax, which is wrong, as the laft crop is frequently not worth reaping. 
- Between Fintona and Five-mile-town, diftance about feven miles; about the former, the foil is thin and cold, the fubstratum much inclined to ftrong tenacious clay. Near this town, algood plan of cutting out a bog for prefent economy, and future profit, is fpiritedly purfued by $\mathrm{Mr}$. Eccles, which deferves particular notice, fince fo, good a fy ftem, I believe, is not to be met with in the county, except near Verner's' ferry, on the borders of the Black-water, which feparates the county of Armagh from this county.

About half way between the above towns is a large mountain called Murley, which makes a great and ftriking feature in the barony of Clogher. This moun. tain affords a great capability for improvement, the furface being in general a, rich peaty foil, with a fubftratum of reddifh clay mixed with innumerable fmall ftones. To render this mountain profitable, nothing more need be, done, than to mix the upper and lower foils, which could be performed at little expence, fince the fubftratum lies only at a fmall diftance from the peat, or rich moor, the depth of which feldom exceeds a foot. Nothing can fupport this obfervation better than the fides of the road through the mountain; where the foils were mixed in forming the road from the water-tables. The white clover fprings immediately, with many other ufeful graffes. This circumftance is not peculiar to this diftrict; it is common throughout 
many of our mountains, but the effects are here mont confpicuous; though I could not difcover, the leaft particle of limeftone-gravel, which abounds in almoft the whole of the low-lands in this barony, and which I Shall prefently take notice of.

In the flat country, below this mountain, which is rich and extenfive, the foil is capable of producing as good crops as any part of the kingdom; generally a deep foil, abounding with limeftone and limeftonegravel, but the latter is but very fparingly attended to. The general crops are potatoes, barley, oats, and flax, and the rotation of them is moft commonly as here fet down, with this difference, that two or three fucceffive erops of oats are taken after barley; but here this fyftem is more pardonable, than in the foils of the county in general. Some patches of wheat are to be met in the barony of Clogher, the culture of which might be extended to a large fcale, as the foils, in general, of this neighbourhood are peculiarly fuited to that grain.

From Five-mile-town to Clogher, diftance about five miles; foil remarkably good for grafs and corn; abounds with limeftone and limeftone-gravel.

From Clogher to Augher, diftance about two miles; foil hallow; and inclining to a reddith hue; limeftone fcarce; crops, potatoes, flax, and oats.

- From Augher to Aughnacloy, by Killybrick, \&c; diflance about fix miles; foil mallow, inclining to clay, very tenacious; crops, chiefly potatoes and oats, fome 
flax, but not abundant. Though the foil about Killybrick and Favoroyal is, in general, cold, wet, and thallow, yet timber trees, in general, fucceed very, well. Some patches of barley about Aughnacloy; but this grain is not much favoured by the foil of this neighbourhood.

From Aughnacloy to Callidon, diftance about fix miles; all gentle fwells and fertile vales; abundant crops of hay, oats, barley, potatoes, flax, and fome rye; foil inclining to red, and, in many parts, abounding. with limeftone and limeftone-gravel; fome marle to be met with in the fertile vales.

From Callidon to Benburb, diftance about fix miles. along the Blackwater, and on to Blackwater town, which lies principally in the county of Armagh. In moft part of thofe diftricts the foils are fertile and well calculated to every kind of grain peculiar to the county, and, perhaps, to the kingdom, if judicioully managed. The exertions, of Doctor Richardfon, of Clonfeckle, near Blackwater-town, in the line of farming; particularly on green crops, fully thew what the fertile foils of the major part of the barony of Dungannon are capable of producing.

From Blackwater-town to the Moy, Dungannon, scc. is beautiful and fertile, almoft beyond defcription. Every kind of crop fucceeds well, when the weather is at all favourable, as the fault of a bad crop can never be imputed to the foil; I win the fame obfervation would hold good with refpect to good management. 
-From Dungannon to Coal-ifland, and along the canal towards Verner's 'ferry, \&c. '; foil in general thin and poor ; fcanty crops of potatoes and oats." s" " " - Agaill, from 'Dúngannon to Cóok's-town;' Stewart's-' town, \&c.; foils in 'generáp decp tahd fertile ; gene-: rally produce every kind of grain and vegetable, peculiar to the county, in great abundance. Very few hills or inountains of 'any magnitudé are within; a'confiderable diftance of Dungannon;" particularly in the ditection of:Cook's-town, Stewart'sutown, Tullyhog, \&c.'

From Dungannon almolt the whole way to Sixi-milecrofs, diftance about fifteen miles; almoft a continued fcene of dreairy bog and mountain. "And again, from the latter village ${ }^{1}$ to within two or three miles of Omagh, an extended flit bog, of feveral thoufand acres, which is fuppofed to be the mont extenfive in the county i Im fure it is the molt unprofitable, and, from its fituation, the molt difficult to be improved.

Here ends a circle through part of three baronies. I thall now proceed upon the different roads leading from Omagh through molt parts of the county.

From Ómagh to Ballygawley, diftance about twelve miles; potatoes, fax, and oats; very thin, light foils. The fame may be faid from Ballygawley to Dungannon, diftance about ten miles.

- To Augher and Clogher, diftance twelve miles; foil and furface nearly the fame as on the Ballygawley rond, and, of courfe, fo are the crops. 
To Fintona, diftance from Omagh about fix miles ; foil in general good, dry, and much undulated; pro. duces, in general, good and certain crops.

To Drumquin, Derg; and Clady, the latter about twenty miles diftance from Omagh. Except within two miles of the town of Omagh, the whole of : this courfe exhibits nothing but one continued fcene of dreary mountain; though the country for feveral miles round Drumquin was, not more than forty years ago, very well wooded, the remains of which are ftill vifible: It is a foil, in general, peculiarly adapted for planting, both for aptnefs of foil, fituation, and eafe in inclofing.

To Newtown-ftewart, diftance feven miles; the whole way an indifferent foil, thin, fubftratum Arong and tenacioas. Much bog and mountain occur in this direction, on both fides of the river. Between Omagh, and the north part of the demefne of $\mathrm{Ranh}$, there are large tracts of excellent feeding-land, along the river on either fides. Except fome fpots about Newtownftewart, there is little or no good land along the banks, the whole of the way to Strabane, except fome trifle on the weft fide of the river, near that town. The banks in many parts are fteep, and of very little value, except for planting, for, which purpofe they are * extremely well calculated.

From Omagh to Gortin, diftance about feven miles." Near Omagh a bog of feveral hundred acres, which will in time be of great advantage to that town: at prefent 
prefent it is in a bad ftate, but is, however, very capable of being improved, which, no doubt, will thortly be the cafe. Good roads is the firft ftep towards the improvement of bogs, in which the bog under confideration is not deficient: fome excellent roads are made, and others are in contemplation.

The remainder of the way to Gortin, except about two miles through Lord Mountjoy's improvements, is nothing but a continuation of rocky and barren mountain, romantic and picturefque to the higheft degree. In moft of thofe rocky features there are fertile veins, where timber-trees, fuch as beech, larch, and Scotch fir, would flourifh apace.

At Gortin, or rather over the village as you go from Omagh, there is a moft extenfive view of many of the Munterloney mountains. The village of Gortin may be confidered the capital of this immenfe region. Before the woods were cut down, the fcenes about Gortin muft have been truly picturefque, and efpecially the banks of the rivers and broaks, which fituations the wood chiefly occupied. Very little wood at prefent to be feen in this part of the country, except the woods of Carrick, the property of Lord Mountjoy, which are in a very flourifhing ftate, and kept in the higheft degree of prefervation. But to return from this digreffion;

From Omagh to Green-caftle, Cook's-town, \&cc.; almolt the whole way is bog and mountain. In approaching 
proaching Cook's-town, however, the foil mends confiderably, and the magnitude of the mountains diminifhes. The lands every where about Cook's-town are of a good quality, and produce abundant crops; the town-parks, with the approaches to them from the main ftreet, are well imagined, and very judicioufly laid out.

To enter into a minute detail of the great variety of foils in this county, would require a large volume; and, after all, perhaps, fufficient juftice might not be done in point of accuracy, fince it is well known, that there are many parifhes in the county, fully defcriptive of all I have here endeavoured to explain, and which, I candidly confefs, is far from the degree of juftice the fubject deferves.

\section{Sect. 5. Mines and Minerals.}

If, under the head Mines and Minerals, we include lime, and other fpecies of ftone, we thall find this county very rich in many; but as lime and freeftone are of the moft general ufe, I thall confine my obfervations to them. But, before I proceed any further, $I$ beg leave to remark, that, in making furveys of counties, or of large diftricts, the fituations of limeftone - quarries fhould be marked upon the map of the furvey. 
Thefe remarks might be further extended; good freeftone quarries might be noted, marle, \&ic. Such obfervations by the furveyor, which could not take. up much time, would be found of great advantage, in pointing out thofe hidden treafures. Clofe inveftigations of thofe fubjects may materially ferve to hew the landlord the true value of his property. Many other advantages would refult from this kind of fpeculation, which at prefent I muft omit to fet forth, and proceed to thew the fituation of fome of the principal quarries and maftes of lime and freeftone.

In the barony of Strabane, there are the following lime and freeftone quarries, with many others of lefs note.

At Lifnagir and Lifnacannan, near Lord Mountjoy's demefne, and about a quarter of a mile weft of the poft-road, are two excellent limeftone quarries of great extent, and peculiarly calculated for the improvement of land, of which his Lordmip's tenants are thoroughly fenfible, fince they carry it fix or eight miles to different parts of the entate.

Mary Gray mountain, eaft of the river Struel, and within a mile of the town of Newtown-ftewart, abounds with limeftone of a good quality; and the quarry is fo circumfanced, that it can never be annoyed by water, which is of fingular advantage in the working of any quarry. 
The Gallions, between Newtown-ftewart and $\mathrm{Du}$ glafs-bridge, are very rich in limeftone, which is allowed to be of the beft quality for building of any in the county.

The above quarries, with others more inferior, are. upon the Newtown-ftewart eftate, the property of Lord Mountjoy; and alfo two celebrated freeftone quarries, one at Cofeik, within three miles of Newtown-ftewart, and the other at Tallynure, on the river Struel, within a fmall diftance of the demefne of Rafh. To the former quarry a great part of the building of Baron's-court, for cut ftone, was indebted. At Duglafs, on the eaft fide of the Struel, and at the Suine, on the weft fide of the fame river, are excellent freeftone quarries, capable of being moulded into any Shape; the latter fupplied Baron's-court buildings with a great quantity of cut Itone.

At Rukkey, within a mile or two of Dunnymanagh, there are immenfe quarries of limeftone, extending a great length along a rivulet. This chain of limeftone appears to be connected with the great limeftone quarry called the Butterloop, in the midrt of the Munterloney mountains, which I fhall, in another place, have an occafion to fpeak of.

In the barony of Dungannon, about Cook's-town and Stewart's-town, limeftone is in great abundance, and alfo about Dungannon, and in many other parts, particularly at Benburb, whofe quarries appear inexhauf-

$$
\text { c } 2 \text { tible. }
$$


tible. I have obferved a chalky fubftance to adhere to 'much of the limeftone about Cook's-town, which does not render it the worfe for either manure or cement. If the ftone be broken very fmall, and applied to land, it is found to anfwer very well without calcination. Here, and throughout a great part of this barony, limeftone is burned with culm, or fmall coal, inftead of turf. At Benburb, culm generally fells at $18 \mathrm{~s}$. by the ton, and the lime-meafure here is thirty-two gallons, which is commonly fold at $1 s .7 \frac{8}{2} d$. per meafure roche, or un lacked.

This barony is by no means deftitute of freeftone, which is fully demonfrated by the towns of Dungannon, Cook's-town, \& c c.

The barony of Omagh is not very rich in limeftone; the principal quarries are in the parifh of Longfield, which are inexhauftible, as are alfo quarries of freeftone of an excellent quality. The moft part of the county is fupplied with mill-ftones from the rocky mountains about Drumquin, in this parifh. Mill-ftones are feldom got in regular quarries in this neighbourhood; they generally are hewn out of fingle detached socks. Mountain or grit-ftone is beft calculated for mill-ftones.

About Clogher, and many parts of the manor of Aughentaine, and alfo about Ballygawley, both in the barony of Clogher, are very rich in limeftone. 
Freeftone does not appear to be plenty, or of a good quality, in this barony.

\section{Coal.}

Coal-ifand, in the barony of Dungannon, is the only part of the county, where coal-works are carried on with any degree of fuccefs. When I faw the colliery in the fummer of 1800 , five pits were working, feemingly very induftrioufly. There is no fire-engine here, nor does it appear, that the works are much impeded by water. There appears, however, to be a great want of encouragement to this bufinefs : the canal at prefent is in a wretched ftate, choaked up with mud and weeds. The approaches, alfo, to the colliery might be materially improved, of which they ftand in great need.

Near Cook's-town fome coals were raifed; but, from the fituation, I am apt to believe, they muft always be attended with much expenfe. Near the town of Dungannon fome pits were funk, and, I believe, fome years ago much coal was raifed. Here a fire or fteam-engine was erected in the fummer of 1800 ; a pit was then finking in the new town of Dungannon, or very convenient to it, from the fituation of which there is much to be apprehended, from water annoying the work.

Withis 
Within two miles of Drumquin, in the barony of Omagh, there appear ftrong indications of a rich coalmine, fituated, I believe, on Mr. Godfrey's eftate, adjoining fome church-land belonging to the fee of Derry. In May 1800 , I fpent fome time there on fpeculation.

Tradition fays, that a water-fpout had, many years ago, fallen on the fpot, where the coal now appears; no doubt, defigned by providence for the good of mankind. Through time, and in confequence of the impreffion made by the great body of water, which the Spout produced, a finall brook took place, which at this time is funk upwards of one liundred feet; fuch is the yielding quality of the foil of the mountain, where this phenomenon was fuppofed to have hap. pened.

It appears to me, that finking a few pits, or fhafts, backwards in the mountain, would be the moft likely way to afcertain the depth of the Atratum of coal; and, if the thicknefs of the mine was found fufficient to be at the expence of following it, inftead of finking hafts in the ufual way, the work might be carried on from the face of the bank, at the furface of the fream, where the coal appears, accompanying the water, in a continued layer, from nine to eighteen inches thick, ftill encreafing in thicknefs, as it advances, in a direction nearly horizontal, rather rifing, which is a good omen. 
There is a large fcope of the fratum vifible, perhaps between three or four hundred feet, before it difappears. From this circumftance there is reafon to fuppofe it runs horizontal, or nearly fo, throughout the mountain, or perhaps throughout all the mountains in this part of the country.

Part of Lough Erne is within eight or nine miles of this place, in a ftraight line. A canal carried circling round the mountains, in the beft line for a canal, probably might be double that diftance.

It is faid, that the waters of Lough Erne are higher than the neighbourhood of the coal mine; this, however, might be proved. From the great number of brooks throughont this mountainy country, it is very probable, that a plentiful fupply of water might at all feafons be procured; but this point fhould be well afcertained, before an undertaking of this kind fhould be fet on foot.

A perfon, Rkilled in Canal works, might be appointed to take the levels, examine the nature of the foil, afcertain the quantity of water, that might be procured from the rivulets and brooks in the fummer feafon, with other ufeful points neceffary to be known. The expence attending all this would be found but trifling, when compared to the many advantages, which might follow from fuch an undertaking.

There are evident figns, of this country abounding in iron ore; and fuch a colliery as the above, if it 
Should be found to anfwer, would, no doubt, encourage the fearching for mines.

The quality of the coal is excellent, having been tried by feveral. I have tried it myfelf, and found it to agree with the favourable reports $I$ have had from others.

The following accounts I have had from Mr. O'Neil, an old refident of Drumquin, whofe veracity I have no reafon to fufpect. That fome years ago he had been examined by Mr. Camac, a well known enterprizing 'gentleman in the mineral kingdom, refpecting this bufinefs; that a Scotch engineer had taken the levels, and in fome meafure affertained the whole expence to be about twelve thoufand pounds, the diftance of the line, propofed for the canal, to the neareft point of Lough Erne, to be about twelve miles; that in a fevere winter, which happened fome years ago, and when it was difficult to procure turf, the Rev. Mr. Daniel, of the parin of Longfield, ufed the coal in quention, in common, throughout his houfe.

\section{Ircn Ore.}

Frnm the fulphureous and ferruginous appearances of water in many parts of this county, there is reafon to apprehend, that iron mines might be procured in large quantities; but the want of the neceffary fuel 
for fmelting, either wood or coals, render this article of no. value, even if found on the furface in ever fuch large quantities. Canals might, in a great meafure, remedy this, as by them the ore might be conveyed convenient to coal, fince wood is out of the queftion, and of courfe will be fo for many years to come.

It is commonly reported, that iron ftones have been found, through the mountains of Munterloney, which have been worked into good iron in common forges; but this wants confirmation.

Clays, fuch as are ufed for Brick or Pottery.

In treating of foils in general, perhaps the article, Clay, might be brought in with fome propriety; but confidering; how unequal pure clays are to the purpofes of vegetation, without the affifance of other foils, I prefume a feparate difcuffion may not be thought improper in this place.

Almoft every parin and town-land affords clay capable of making bricks of various colours, but the pale brick is deemed the moft durable.

About Fintona, in the barony of Clogher, good flooring and ridge tiles are made; garden pots, and a great variety of crockery ware for country ufe. The beft pottery in the coupty, and perhaps in the kingdom, is within a mile of Coal-illand; on the road to Verner's 
ner's ferry, in the barony of Dungannon. Here are manufactured all forts of rough crockery ware, fire bricks, and tiles for malt and oat-kilns, of as good 2 quality as any imported.

The clay, before it is baked, is of a dirty white; the beft of it is made into fmall oblong pieces, of about a pound each, which is dried to the fun, and fold on the fpot at a penny each. It is ufed as a fubftitute for fullers earth, for cleaning leather breeches, \&ic. For this purpofe it is fent to many diftant parts, and brings a profitable return.

\section{Sect. 6. Water.}

There are few counties in the kingdom better fupplied with water, than this county. The Blackwater accompanies it for upwards of thirty miles, dividing it from the counties of Monaghan and Armagh for the whole length of that courfe, and at length falls into Lougneagh at Maghery.

'The principal river is nearly central in the county, and goes under various names; the part of it, which lies above, or, to the fouth of Omagh, and fomewhat north of the town, goes by the name of Cammon, or Camaun. From thence to Newtown-ftewart, it goes by the aame of Struel, which appears to be newly coined. 
Between Newtown-ftewart, and Strabane, and fo on to Lifford, it goes by the ancient name, the Mourne; and from thence forward to Londonderry, by the general name of the river Foyle.

In its progrefs through the county it receives fome confiderable rivers, and brooks, or, as they are here called, burnes, innumerable, as every mountain produces its part of a brook, and almort all the brooks in the county ultimately join the river Mourne.

At Omagh, or a little to the eaft of it, two confiderable rivers meet, namely, Drumragh, and a mountainy river; in the neighbourhood of this junction, I fuppofe the name Cammon is affumed, the word being derived from crookednefs, or fudden bends, which here occur' frequently. Below Omagh, about two miles, the Poa, or the Fairy water joins. Near Newtown-ftewart, two confiderable rivers fall in, namely, the Gortin, and Glinnelly rivers, the junction of which is at Corick woods, about three miles eaft of Newtown-ftewart. At Ardftra, the river Derg joins; and below Strabane near Lifford, comes in the river Fin, which divides this county from that of Donegal, as far as the village of Clady.

The lakes of this county are poor and infignificant, if we except, Loughneagh, which only mears a fmall portion of it; the lakes at Baron's-court feem to be the largent, and are by far the molt interefting in the county, as being, or compofing part of the 
Marquis of Abercorn's demefne, and which at molt feafons of the year appear to great advantage.

A fmall lake at Augher, in Sir William Richardfon's demefne, is beautiful, and happily circumftanced: There are feveral fmall lakes, or rather pools, in the baronies of Dungannon, Clogher, and Omagh, but very few in the barony of Strabane; I believe there are not more than two or three in the latter barony; at leant, I do not recolleçt any more. 
CHAP. II.

AGRICULTURE.

SEct. I. Mode of Culture.

FROM the great variety of the foils of this county, it muft follow that there are various modes of culture.

I believe there are not better potatoe and flax farmers in the kingdom, than thofe of Tyrone in general are; the only branches of hufbandry they excel in, or have any pretenfions to. And, though we feldom find large tracts of potatoes together, yet we meet with innumerable fmall patches throughout the county, in many parts almoft up to the fummits of the highent mountains. This is a ftrong indication of the populoufnefs of the county.

The fame obfervation holds good with refpect to nax, as it is as common for the poor man to have $a-$ lot of the latter, as of the former, fince without both he could not exift. It mult, however, be remarked, 
that there are many mountainy fituations, which may anfwer for potatoes, where flax would have no chance; in fuch, oats always follow potatoes, as there barley would not fucceed. It is an old remark, that, "where barley thrives, fax is fure to fucceed after it."

Oats are moft commonly fown on onc ploughing, which is performed fometimes before, but molt commonly after Chriftmas; but this mode is obferved only in good barley foils, and moft commonly after it, and fometimes after flax. In mountainy foils, where oats follow potatoes, as has been already obferved, ploughing never takes place till immediately before the time of fowing.

Twenty ftone is the ufual allowance of oats to the plantation acre (I always mean the plantation acre), which generally returns eight barrels, of eighteen ftone to the barrel. Sixty ftooks, of twelve meaves to the ftook, are reckoned a good crop for an acre to produce; and, when fodder is at a reafonable rate, the value of the ftraw is about thirty hillings, but it is moft commonly higher. The fraw is confidered to be equal to the expence of ploughing, harrowing, reaping, and making up.

As, in good land, flax generally fucceeds oats, two ploughings are always given; the firn before or after Chrifmas, and the fecond juft before the time of fow. ing. Forty gallons is the ufual allowance for an acre, and one-fixtls lefs for a Cunningham or Scotch acre; 
the latter being the common meafure, by which the farmers regulate all the land let to poor cottiers, in the corn-acre way (a phrafe, ufually underftood in this country to denote a yearly take, or letting the land only for one crop), though the farmer himfelf may rent his land by the plantation acre. This is a grievance on the poor, which certainly hould be redreffed.

It is very common to fow flax after barley, when the land is not in good heart; and, in fuch cafes, the fucceeding crop is oats, and then the land is fuffered to reft for three or four years in a fate of nature, moft commonly without affiftance from grafs-feeds of any fort.

Potatoes are generally planted on lea-land, ploughing for them being very feldom practifed, efpecially by the poorer clats; but this practice is chiefly confined to the baronies of Strabane and Omagh, which, I dare fay, are equal to two-thirds of the whole county. The farmer finds great advantage in giving sough ground to the cottier, who muft either put up with it, or want. When the land is ploughed, and fufficiently pulverifed, the crop is generally double that produced, in the ufual way of planting on the lea. However, though the poor man may be much forely diftreffed, by being every year obliged to plant rough land at the farmer's option, yet the community at large reap the benefit of it, as land is fooner gained, and brought into a profitable courfe of cultivation. 
The induftry, with which the poorer clafs fet about collecting manures, is moft praife-worthy; a full account of which Shall be given in its proper place, under the article Manures, which fee.

\section{Objervations on the foregoing Section.}

Is lea ground, two fucceffive crops of potatoes would be found of more general advantage than one. To the owner of the land, perhaps, in fome cafes, one crop only may be more for his intereft, as he will have, of courfe, more rough ground brought into culture, than he could have by taking off two fucceffive crops. If the foil be ftrong, and difficult to pulverize, two potatoe crops Mould certainly be preferred, without an intervening crop.

But the farmers of this country are remarkably fond of barley crops, as they are always a ready money article; indeed they are frequently bought up by private diftillers, feveral months before they are reaped; this temptation frequently fuperfedes every other folid advantage.

Half the quantity of manure, ufed for the firft crop of potatocs, will ferve for the fecond, and the latter never fail in being moft abundant; and, if the drill fyftem be followed, there will be a great faving of feed and labour. 
-By following this. fyftem it is very obvious, that the quantity of food may be confiderably encreafed, though not fo much land may be brought into cultivation in the fame fpace of time. I am not, however, perfectly clear, but more grain may be obtained, on account of the good preparation the land will undergo, by taking off two crops of potatoes, than in the ufual way of taking only one crop.

A country may be overfocked with barley, and it is too frequently the cafe in this kingdom, the effects of which are forely feit by the lower clafs, from the immoderate ufe of fpirits, when it becomes fo cheap, as to be within the reach of every common labourer. But the cafe is different with refpect to potatoes; there cannot be too many of them. As long as Britain retains a navy, there will be a demand for pork. Potatoes are not only the food of man, but are alfo that of horfes, cattle, pigs, and poultry; theep, alfo, are eafily taught to eat them.

One great advantage to farmers and labourers may derive from having plenty of potatoes, as, in fpring, milk and butter is always fcarce; beef and mutton, at that feafon, are entirely out of the reach of the lower order; pickled pork may be had upon cheap terms, when potatoes are plenty. A pig, killed at Chriftmas, may go a great way in fpring, by pickling part of it, inftead of making bacon of the whole, as is ufually done. A pound of pork, in fpring, 
with leeks, oatmeal, greens, \&rc. would go further than two pounds of bacon in a family, and would be found confiderably more nouriking.

SECT. 2. Extent of Culture, and of eacb Species of Grain forved.

BEFORE I proceed on this fubject, I beg leave to remark to the Board, that it is my humble opinion, this fection might be fomewhat imperfect, without includ. ing potatoes in the difcuffion; therefore I thall take the liberty of giving them a place with the grain.

It is impoffible to be accurate on this fubjeçt, without making an actual land furvey; and this could only ferve for one feafon, fince the quantity of land, under culture, muft always vary according to circumftances, fuch as the encreafe or decreafe of population, \&c.

Perhaps the beft method of determining this point is, by attending to Doctor Beaufort's Memoirs, where he ftates the county to contain 28,704 houfes, which ftatement at this day is fufficiently accurate, notwithftanding the fuppofed reduction of the inhabitants by emigration, raifing militia, \&c., which, in the whole, are fcarce worth attending to. I believe, with many others, that the county is more on the encreafe than on the decreafe.

From 


\section{OF THE COUNTY OF TYRONE.}

From feveral views I have taken in different parifhes, I am clearly of opinion, that the number of perfons, or rather the average to each houfe, is rather over than under fix; but I thall abide by that number, which would make the whole of the inhabitants of the county equal to 172,224 .

What remains to afcertain is, to thew what quantity $2 \$, 70$ of land is fufficient to fupply a family, confifting of fix perfons, the year round. This, from repeated obfervations in feveral parifhes, I have determined fufficiently accurate to anfwer our prefent purpofe.

The cultivation, neceffary to fupport a family of the above defcription (no matter whether part be children or not, as children wafte food, and are fuppofed to be equal to grown-up perfons), I ftate as follows:

3 acres of oats; - Quantity of feed, 60 ftone.

$\frac{1}{2}$ ditto, potatoes, - ditto, - 80 ditto

$\frac{x}{2}$ ditto, barley, - - ditto, - 8 ditto

$\frac{3}{8}$ ditto, flax, - - ditto, - 15 gallons

$\frac{1}{6}$ ditto, garden and haggard.

$4 \frac{\frac{x}{2}}{2}$ total cultivation, which, multiplied by 28,704 houfes, gives, for land in cultivation, 129, I68 acres, of which the proportion is;

For oats,

- 86,IIr acres

- potatoes, - - 14,352 ditto

- barley, - - 14,352 ditto

- flax, - - 10,764 ditto

- gardens, \&c. - 3,588 ditto

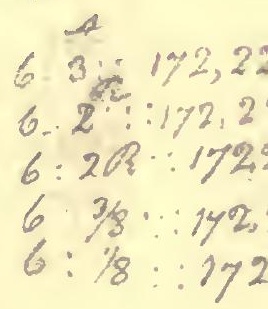

129,168 ditto

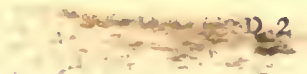

The 


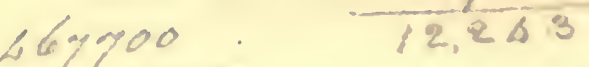

The above account fhews, that a confiderable deal more than one-fourth of the county is in cultivation; the whole number of acres in the county, according to Doctor Beaufort, being 467,700 .

In taking a general view of the county, this great tract of cultivation does not appear to occupy fo much fpace, as what in reality is the cafe; the reafon is, that mountainy and hilly lands meafure more to the eje, than flats and low fituations, which are, of courfe, chiefly occupied in culture.

It has been hewn, that 3 acres of oats require 60 Stone of feed; 86,112 acres will require $1,722,240$ ftone, or 95,680 barrels, of 18 ftone to the barrel.

Half an acre of potatoes requires 80 ftone of feed; 14,352 acres, by the fame rule, will be found equal to $2,296,320$ ftone, or 114,816 barrels, at 20 ftone to the barrel.

With refpect to the quamity of land, barley is equal to potatoes, which, at fixteen ftone to the acre for feed, will be found equal to 229,632 ftone, or 14,352 barrels, at 16 fone to the barrel.

Forty gallons of flax.feed are ufually fown on an acre; 10,754 acres will require 229,632 gallons, or 6,145 hogheads, allowing 70 gallons to the hoghead; but this meafure is never uniform. 
The wubole may be thus fated,

\begin{tabular}{|c|c|c|c|c|c|}
\hline Species. & Acres. & $\begin{array}{l}\text { No.of bar- } \\
\text { rels forve:l. }\end{array}$ & $\begin{array}{l}\text { Aver. } \\
\text { peracre. } \\
\text { barrels. }\end{array}$ & $\begin{array}{l}\text { Amount. } \\
\text { barrels. }\end{array}$ & \multirow[b]{2}{*}{$\begin{array}{l}*_{\text {grond and }} \\
\text { bad land. }\end{array}$} \\
\hline Oats. & 86, I I 2 & 95,680 & $7^{*}$ & 602784 & \\
\hline Potatoes. & 14,352 & $I_{14}, 8$ I 6 & 80 . & I I 48 I 60 & \\
\hline Barley. & 14,352 & 14,352 & Io & 143,520 & $i$ \\
\hline Flax. & 10,764 & $6145^{*}$ & & - & * Hog beads \\
\hline Garden, \&c. & 3588 & & & & \\
\hline
\end{tabular}

Here it may be neceffary to remark, that the garden and haggard is commonly the fame, but is always filled with crops in fummer, moft commonly cabbage. This part only ferves to hew the quantity of land, counting nothing on the feed fowed, or the produce, as is Ihewn in the ketch above Itated.

In the foregoing ftatement, half an acre of oats is allowed for feed, and a fmall quantity for horfes, whofe allowance of this article indeed is moft commonly fcanty and precarious; four barrels of potatoes are alfo deducted from the produce of the half acre, for an allowance of feed for the next feafon; the half acre of barley makes no part of the food of the family, yet ferves to thew the extent of culture and quantity of feed fowed; and the reafon is, be- 
caufe this grain generally follows potatoes; indeed it is always the cafe in good land.

Two and 2 half acres of oats I place againft a houfe, or fix in family; the produce in meal, upon an average, $r 7 \frac{1}{2} \mathrm{cwt}$. allowing $\mathrm{r} 2 \mathrm{olb}$. to the hundred, which I for oatmeal is the general Itandard, being with more cafe turned into pecks of rolb. without fractional parts. This allowance will be found nearly one pound per day, to each perfon for the year round.

Thirty-fix barrels of potatoes* are the common produce of half an acre, after deducting four barrels for feed. This allowance in the grofs, to the whole family, will be found better than $4 \frac{1}{2} l b$. daily, to each individual. Between meal and potatoes, the daily food for each perfon will be found to exceed $5 \frac{1}{2} l b$. which, with the hiclp of the garden in fummer, may be confidered an ample allowance. Pigs and dogs, of courfe, muft fall in for their hare; the latter, from their great number, certainly deftroy more food than the former; but this wafte of food our country rareJy confiders as a grievance. How many pigs might be fed, throughout the kingdom, with the food thrown away upon ufelefs dogs, which are, by far the greater part, a peft to the community.

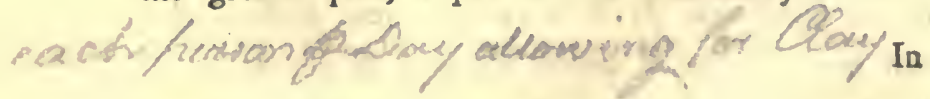

* Of 20 ftone to the barrel; for eafe in calculation, I prefer the 20 ftone barrel, though the ftandard of the county is generally 40 Stone to the barrel. 
In this place it may be neceffary to remark, that, fo far as barley immediately follows potatoes, the calculation will hold good; but "this is not always the cafe, fince, in mountainy fituations, oats muft neceffarily follow potatoes; however, in fome cafes, where the foil is very good, it is common to fow barley after the laft crop of oats (which Thall be Shewn in the next article); but for this, a dreffing of manure muft be ufed. This additional crop of barley I fhall let ftand, againft the want of barley crops in mountainy fituations.

I believe it is fcarce neceffary to remark; that very few cottiers are exactly circumftanced according to the above ftatement; cottiers, in general, have not a third part of the allowance here fet down, from the farmers; which mall be taken notice of in its proper place; the difference muft be purchafed, moft commonly by the induftry of the loom.

The quantity of flour ufed, or, which is the fame, the wheaten bread made ufe of, by the better fort of people, and particularly in the principal towns, may be confidered as a draw-back from the above ftatement; but the very few, who are accuftomed to wheaten bread, make but a fmall bulk, when compared to the community at large. 


\section{Sect. 3. Courfe of Crops.}

I. Courfe, but not the moft general is;

I oats.

2 do.

3 flax.

4 oats.

The above is moft commonly followed in lands formerly taken in, and which have been allowed to reft for a few years after the firft courfe. The fecond rotation, and fometimes the third and fourth, is generally the fame as the firft. 'This is a molt abominable fyrtem; the land is never fuffered to reft any length of time, and the laying down with clover, or any kind of grafs-feed, is generally out of the queftion.

Except about Strabane, and Omagh, very little attention is paid to the laying down with grafs-feeds.

2. The following courfe is the moft univerfal, and is by far the moft rational, particularly for the baronies of Strabane and Omagh.

I potatoes, upon lea land.

2 barley, upon one ploughing in April, or May.

3 oats, upon one ploughing about Chriftmas.

4 flax, upon two ploughings, the firft about Chriftmas, and the next immediately before the time of fowing, which is generally about new May.

5th. Oats, 
5th. Oats, and then the land let out for a few years as before. If the land be in good condition, barley generally follows this crop of oats, but the foil mu?t be highly manured; after this follow oats, and then flax, and fuffered to reft as before.

Here are eight fucceffive crops running; without any kind of meliorating crop.

There are many however, who follow a better fyftem; they ftop after the laft crop of barley, by which means the land is let out in good heart, and, of courfe, will come round for a fecond courfe in a fhorter time.

To this practice, if the fowing of grafs-feeds and clover, when the latter might be thought to fucceed, was added, much benefit would certainly. enfue.

3 d. Courfe, commonly followed in mountainy fituations.

1 potatoes.

2 oats.

3 aats.

In fome mountainy fituations, a third crop of oats is taken off, but this rarely happens.

In boggy marfhy fituations, a fourth fyftem is followed, which I look upon to be the moft profitable of any.

Part of the foil is burned for alhes, fufficient to manure a crop of potatoes: Two crops are generally taken off, and then it is laid down, moft commonly with 
black oats, which frequently lodge, and rot in wet feafons. Notwithftanding this, a moft luxuriant verdure foon takes place, without any affifance from bay-feeds; the white meadow grafs (Holcus lanatus), being peculiar to fuch foils, foon occupies the furface.

This mode of bringing in land has of late years been very much attended to, which the people find to their advantage, in point of gaining annually a confiderable acquifition to meadow land, the want of which is the greateft inconvenience this county labours under.

\section{Obfervations.}

15, inftead of always following potatoes with barley in good foils, we were occafionally to introduce wheat, no doubt we would get into a better habit of living, with refpect to food, than is at prefent the cafe. The leffening the confumption of fpirits, and the getting into a mode of ufing wheaten, and rye bread, (which fhould be generally mixed, for the ufe of labouring people) are two objects of great importance to the community. Oatmeal is not calculated for making bread; it is well known, that a pound of it will go farther in a family, made into hanty pudding, or firabout, according to the general phrafe, than a pound and a half made into bread; and yet, notwithftanding all this, I find there is a confiderable deal more meal 
ufed in bread throughout the county, than otherwife. The people of the province of Leinfter are very fenfible of this, and, very properly, convert the greater part of their oatmeal into ftirabout, and ufe wheat and rye, and fometimes peas, for bread. The foregoing grains are commonly mixed, and, when fo, are called in fome parts braccas, as in the county of Kildare, and in other parts mefin, as in the county of Louth.

It is faid, that the foils of this county are not calculated for wheat and rye, and particularly for the former. I know they are not generally fo, but it is very notorious, that many of them are, from fome fuccefsful trials, which have been lately made in the neighbourhood of Omagh, the foils of which are by no means deemed fo well calculated for wheat, as a large portion of thofe of the baronies of Dungannon and Clogher, which, in my opinion, are as good wheat foils as any in the kingdom. A ftrong abiding loam, inclining to limeftone-gravel, is allowed, by the beft judges, to be moft favourable to wheat, which is in great abundance in the above baronies. In every part of the county are to be found fpots of rich bog, which produce abundant crops of potatoes. In all fuch places, rye would certainly fucceed, after a potatoe crop: but by far the beft economy would be, to have rape after potatoes, as part of fuch grounds are in general burned the year before, to manure the potatoe crop. The laft crop, or that after rape, Thould be rye. 
The fpring is the feafon of fevere trial for food for cattle: a little rape at that time would be found of infinite ufe, the procuring of which is almort in the power of every farmer: the feed is of little or no value, and the foil is prepared to his liand by the late crop of potatoes.

Wheat and rye fraw will laft double the length of time, for thatch, as oat and barley ftraw; this would be found of the utmoft confequence, in point of encreafing manure.

From what I have faid upon this head, I beg it may not be underftood, that $I$ win to leffen the quantity of oats raifed: if horfes, pigs, and poultry were fully ferved, the whole would be found little enough, with the addition of the wheat and rye, that might be raifed.

SECT. 4. Ufe of Oxen. W. . . .

Very little ufe is made of oxen in the county. Some years ago, in Lord Mountjoy's demefne, oxen were found of great ufe for ploughing deep foils, where it was neceffary to plant, which was performed by the Kentifh wheel-plough, drawn by fix bullocks, which commonly were harneffed by the yoke placed to the fhoulder of the animal. This fubject, with many others relative to improvements, I mean to :eferve for a fepa- 
rate chapter, which fhall include the bulk of the im: provements of $\mathrm{Rah} *$ demefne and its appendages, as it is apprehended, that a curfory view of thofe extenfive improvements might not do fufficient juftice to the fubject, nor would the reader be able to comprehend them in fo clear a light, as if brought under one general head.

It is not uncommon, in many parts of the county, to meet, among the farmers, fmart active little bullocks, employed in the flide-car (which fhall be taken notice of in the next fection), drawing turf, manure, limeftone, \&c.; and, from the habit of being in company with horfes, they move as faft as them. 'It alfo frequently happens with a poor farmer, who may have the misfortune to lofe one of his horfes in fpring, to be obliged to join a bullock with a horfe to plough his land; indeed there are frequent inftances of his being obliged to yoke his cow for the fame purpofe.

In a mountainy country, as this is, and where the farms in general are fo extremely fmall, horfes will always fuperfede oxen in cultivating the foil. In level countries, and where there are large farms, where a long, fteady courfe of tillage is the principal object,

oxen

Rafh is the prefent name, which is derived from a rath, or Danifh fort. It is in contemplation to change the name to Mountjoy Park. 
oxen can be only employed to advantage.

The common trace and collar is the general mode of harnefing in ploughing.

\section{SECT. 5. Nature and ufe of Implements of Hufbandry.}

VERY little can be faid, in general, in favour of our implements of hußbandry.

The common plough is a moft wretched implement; it performs very badly, and, from its conftruction, is very difficult to draw. Inftead of having the coulter in a line with the land fide of the fock, or ploughmare, it is generally placed an inch nearer the land, or to the left hand; and, inftead of the coulter being fet a little before the fock, it is placed rather behind it, fo that, by this means, the draught is confiderably encreafed. On account of the point of the fock not being guarded by the coulter, the former is always made of iron, inftead of metal, which is always attended with trouble and expence. From this mode of fixing the ploughirons, it is plain there are two obftructions to encounter with, in place of one: the fock rather opens the land firft; the coulter cuts after, but nerer a clear or fair open furrow, which may be eafily conceived.

Some gentlemen there are, however, who follow a better fyftem. A plough got fome years ago from Collon, one from Lord Longford in the county of Weftmeath, 
Weftmeath, and one from Mid-Lothian in Scotland (all at Rafh), are beginning to open the eyes of the neighbouring farmers. Thefe acquifitions, with the fpirited exertions of Mr. Buchanan, near Omagh, who is moft indefatigable in the ufeful purfuits of agriculture, I hope will, in a fhort time, reform our fyftem; indeed already there are vifible appearances of a reformation.

Almoft as little can be faid in favour of the harrow, as of the plough. There is only one kind in general ufe; it confifts of four baulks or main pieces, containing twenty pins or tines, and is commonly drawn on the angle. Sometimes two harrows are faftened together, efpecially in dry weather, and at the time of feed-fowing; in this cafe, two cattle are made ufe of, yoked abreaft. The fingle harrow is commonly drawn by one beaft.

In ploughing, more than two horfes are feldom ufed, and, in many fituations, that number is fufficient. It is a well-known fact, however, that the fanty crops of oats we commonly meet with, and particularly the fourth and fifth in courfe, may be chiefly attributed to thallow ploughing. There cannot be a more clear inftance of this, than what has repeatedly occurred at Rafh, in laying down the fmall diftricts occupied by farmers and labourers, who knowing, that they would be obliged to give up at ftated periods, inewed no mercy, but cropped on every year with exbaufting crops, 
crops, of courfe, oats and flax. But, notwithftanding the extreme poverty, in which they left the land, one deep ploughing, performed by four or fix ftout cattle, never failed to yield an abundant crop. But to return;

About twenty years ago, very few wheel-cars were to be met with, except in the neighbourhoods of principal towns, fuch as Dungannon, Omagh, and Strabane; now every farmer, of any note, is poffeffed of one or more; though, in many fituations, it can never be applied fo ufefully as the common nide-car; notwithttanding, the farmer, who is able, feels a pride in having a wheel-car, though frequently of not much more ufe to him, than that of going occafionally to markets or fairs.

In the hilly and mountainy parts of the country, the nide-car muft always prevail, as being capable of accefs, where a wheel-car would have no chance of acting. The price is from $35.9 \frac{1}{2} d$. to $55.5 d$. when bought at the fair or market, and it will laft, with care, three or four feafons, but muft be frequently fupplied with new feet, which generally coft fixpence-halfpenny a pair: but more of this, when I come to treat of the general prices of timber.

Two and one-half cwt. is generally the load of a nide-car, three of which are deemed equal to that of a wheel-car. The whole expence of a wheel-car is about four guineas, which may latt five or fix years, according to the manner it may be employed. 
To a perfon, accuftomed to wheel-cars, the nide ones, at. firft view, muft appear aukward, which, indeed, was the cafe with myfelf fome years ago; but now I am thoroughly convinced of their great utility in mountainy fituations. Even in countries not over mountainous, I am not altogether clear, but the nidecar Thould have the preference. It is amazing to find with what celerity a fmall horfe, worth about forty Shillings, with one of thofe fimple vehicles, will get through fo much bufinefs in a feafon, in drawing manure, turf, limeftone, \&c. In fteep hills, rough, uneven, and fwampy fituations, the nide-car may be ufed, where the other could have no chance to fuct ceed. The average expence of a wheel-car, with weat and tear, may be about a guinea a year, whereas that of the other may not exceed half a crown.

The reader, who may not be acquainted with the nide-car, even by the name; may conceive fume idea of it from the following fketch.

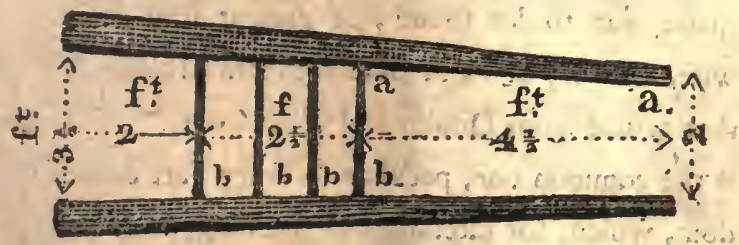

The body, from $a$, to $a$, is ufually the length of that of a wheel-car, according to the fize of the beaft; the fame may be underftood of the breadth. The body is 
made of oak, alder, birch, or any other wood whict: may be convenient. The rungs, $b, b, b, b$, are generally oak or hazel. The car is commonly ufed for fome time before the foot is applied, and, upon the application of which, the fide of the car is thus reprefented.

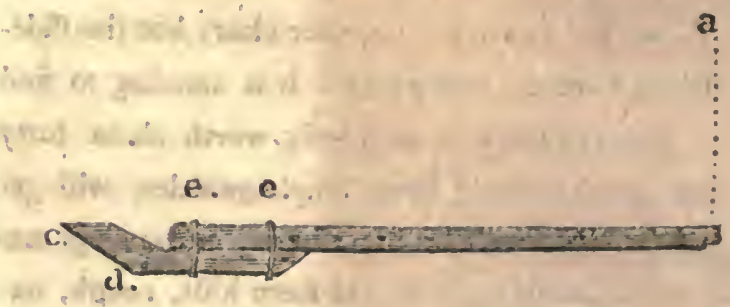

- When the rhaft of the car is raifed to $a$, (the fuppofed height when the beaft is yoked), the fpace $c, d$, will be found horizontal, or at leaft it will take that direction, when the car has becn fome time at work. In drawing over hard foils, the feet foon wear out, and mant be frequently replaced. The fraps or belts $e, e$, are fometimes of iron, but moft commonly gads, made of hazel or fallow.

Spade and Shovel.-Some years ago, fcarce a good fpude was to be found; at prefent it is quite otherwife, as every town of note is plentifully fupplied with that article from Dublin and other parts. The movel is the common one, peculiar to every part of the kingdom, which, far ditching and draining, is certainly the beft.

A mill, for manufacturing fpades and hovels, has beẹn dately eftablihed at Fintona, by Mr. Hugh Kelly 
of that town. I' find, from fair trial, that the fpades are as good as any, which have been brought from other parts. At Newtown-ftewart, by Mr. Bartin of that town, another fpade and fhovel-mill is about to be fet up.

Pick-axe and Crow-iron.-Formerly the pick-axe was feldom ufed in finking drains and ditches; the crowiron was the chief implement for that purpofe. The former is at prefent in moft general ufe, being lefs laborious to the workman; befides, in moft cafes, it is beft for quick difpatch. In heávy ftrong foils, and where large ftones interfere, the latter is preferred, being more powerful for weighty works.

Forks, rakes, reaping-looks, fcythes, \& \& , are in common with other counties.

I cannot pafs over a fimple implement, peculiarly adapted to this county, and which, I believe, is tole. rably general through the North, though not fo in other parts of the kingdom. The old Irim name is Akrogboge; the word ferogh being generally ufed for fod. I thall here call it a fcraw-cutter.

It is ufed for cutting fcraws or fods, to lay on the houfes, between the wattling and the thatch, which contribute very much to keep them comfortable and warm, and alfo faves thatch. The fods are cut about two feet broad, and from an inch to two inches thick; the length is determined by the depth of the roof; for example, 2 roof of fourteen feet in depth will require 
a fod of fixteen feet, 25 it munt lap over the vertex, and come down to the outfide face of the wall. They are rolled upon a ftick, and carried up the ladder by two men, who perform their work very dexterouny. An active man can cut from thirty to forty fods of the above dimenfions in a day, and the general price is a penny a fod, but he muft affift to lay them on the roof, and fit them there, which requires fome degree of ingenuity. Uader is a fketch of the feraw-Gutter.

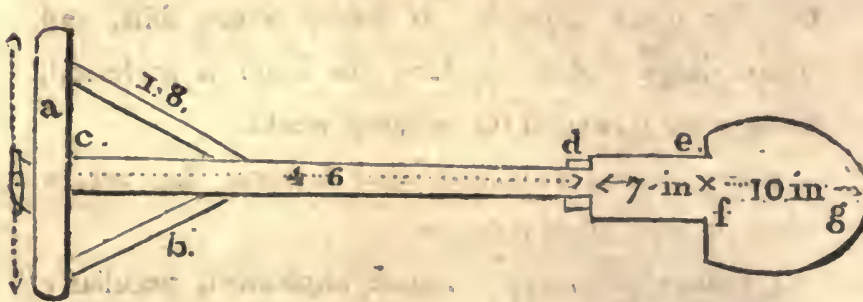

The crofs piece $a, 2$ feet,

Brace, $b, 1$ foot, 8 inches,

Length from $c$, to $d, 4$ feet 6 inches,

from $d$, to e, 7 inches,

- from $f$, to $g$, 10 inches, and about the fame in breadth. The rife, or upfet, from $d$, to $g$, is to be confiderably more than that of the bed of a fpade.

Sect. 
SEcr. 6. Markèts for Grain.

ALThough there are feveral market towns throughout the county, yet very little grain is fold at any of them. Oats and barley are generally fold by fample. Oatmeal and potatoes are the chief articles of food, fold in the public markets. The principal markets are, Dungannon, Stewartftown, Cookftowñ, Aughnacloy, Augher, Fintona, Omagh, Newtownftewart, and Strabane; there are a few others, but of very little note.

Flax-feed abounds in every market, in fpring, not only in market towns, but even in fmall villages, and detached houfes through the country. It is always bought from the merchant by the hoghead, which generally is from fixty to feventy gallons; it is retailed by pecks and gallons; five of the latter are fufficient to fow half a rood, or twenty fquare perches of land, being in the proportion of forty gallons to the acre.

Moft commonly, great profits are made by retailing flax-feed; I have known them to amount to forty per cent.

Some years ago, in confequence of premiums granted by the Dublin fociety, or the Linen board, large quantities of flax-feed of Irin growth were fown; but this practice, with great propriety, has been laid afide.

Sect. 
SEст. 7. Uje of green food in winter.

Fow in the county know what is meant by grees food, much lefs have they any knowledge of the application of it.

Some are very induftrous in planting large quantitics of cabbage in their gardens, which they never let go to lofs, as the cows and pigs are fure to be ferved by what the family cannot make ufe of ; this about Chriftmas affords a temporary relief. In fpring which is the trying feafon for cattle, as at that time fodder of every fort becomes fcarce, the only refource for green food, if I may fo call it, is the tops of furze, which are ufed in large quantities for horfes. The young tops are pounded, or bruifed, in a ftone mortar; but this operation is very tedious, as it will take a man, the greater part of the day, to prepare food for two horfes. When bruifed, they are mixed with a little oats, and make excellent provender, which all our farmers fully experience. A machine, or fome improvement, upon this head, would be found of infinite advantage to the public. I have feen flax broken, for the fcutchers of a flax-mill, by wooden fluited cylinders, and am of opinion, that furze might be bruifed on the fame principle. This might be worth the confideration of fome ingenious artin. 
Inftead of green food; oat-chaff and fmall potatoes are boiled together, which are well known to be wholefome and nourining for cattle and pigs, and never fail to encreafe the quantity of milk. The milk is alfo encreafed by boiling hay in water, which encreafe is more or lefs, according to the quality of the hay; the clofe jointed graftes, in general,' afford the richeft hay-water, of which the bent graffes form not the leaft part.

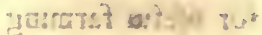

There is a fpecies of grafs very common in all low fituations, and efpecially in rich bogs, called the creeping bent grafs, the agroftis ftolonifera of Linnaeus : from the faccharine and fucculent quality of this grafs, it is extremely well fuited for making hay-water. The natives call it the foreen-grafs; the joints are very numerous, and ftrike root at every one; it creeps along the furface to a great diftance, attaching itfelf to the perpendicular fides of drains and bog-holes, or any other fituation, where its numerous roots may chance to grafp. The beft way of encreafing it is, to cut the hay with a knife, or rather with a frawcutter, which if fown like hayfeeds, in moilt fituations, and covered with about half an inch of rich boggy foil, in moift weather, every joint will fucceed, as I have more than once experienced.

It is not eafy to collect the feed pure, nor is it apt to ripen well. A fuller defcription under the article, Natural grafjes, which fee. 
It would be unpardoinable in me, were I to quit this fubject, without taking notice of Dr. Richardfon's fyftem of courfes of crops, and green food, in the parifh of Clonfeckle, and barony of Dungannon. When-I was there in July, 1800, I' faw fome crops of rape, managed in a mafterly manner, and with a perfect view towards economy. This gentleman feems to poltefs, in a great degree, both the fpirit and talent for ufeful farming.

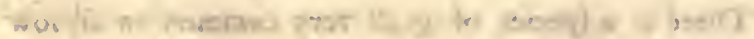

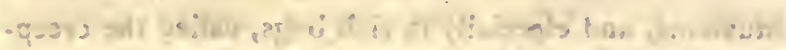

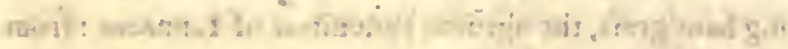

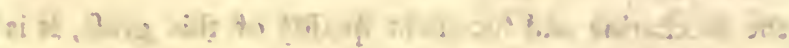

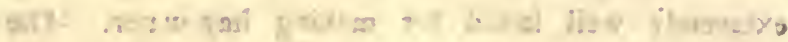

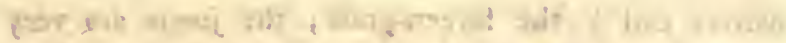

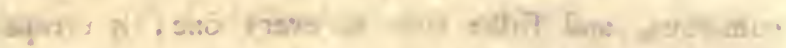

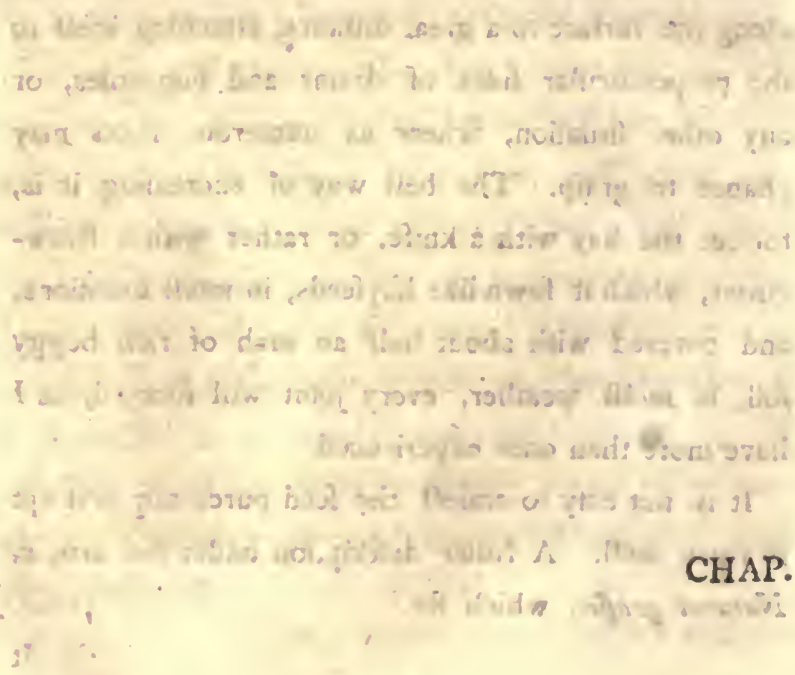




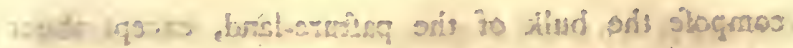

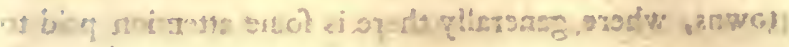

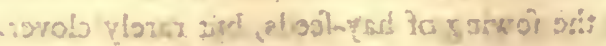

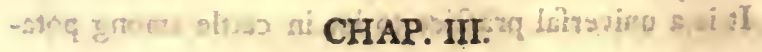

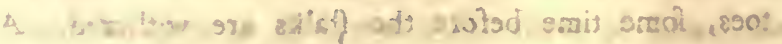

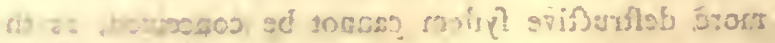

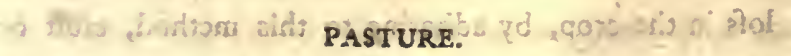

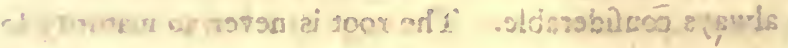

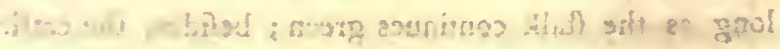

SECT. I. Nature of Pafture.

FROM the mode of letting lands reft a few years, in fome meafure to recover naturally, without the affintance of clover and hay-feeds, or either, good pafture-land cannot be expected. The principal paftures are thofe, which the plough and fpade have not hitherto been able to attack; namely, holmy* land, cone fidered too wet and precarious for tillage; rocky and Ikrubby land, out of the reach of a farmer to bring into culture; mountainy foil, deemed not capable of bringing crops of corn to maturity; and bog and marihy foils, as far as cattle are able to make their way into them, and; in attempting of which; many are loft.

The above, with what the cattle may be able to pick up; after the crops of corn are carried off, chiefly

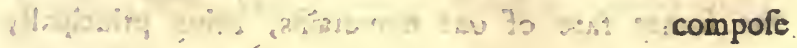

- Low flat land, fituated generally in the vicinity of brooks and rivers. 
compofe the bulk of the pafture-land, except about towns, where generally there is fome attention paid to the fowing of hay-feeds, but rarely clover.

It is a univerfal practice to let in cattle among potatoes, fome time before the ftalks are withered. A more deftructive fyftem cannot be conceived, as the lofs in the crop, by adhering to this method, muft be always confiderable. The root is never at maturity fo long as the ftalk continues green; befides, the cattle tread the land to fuch a degree, that frequently a great part of the crop is expofed, and, if it hould efcape the froft, is, notwithfanding, otherwife materially injured. The foil is alfo rendered fiff by the cattle walking over it, which, of courfe, muft always encreafe the expence of digging out the potatoes. Add to this, that, if the land be retentive, or inclined to clay, water will lodge in every impreffion made by the feet of cattle, which, in a thort time, will caufe the crop to rot.

which, in a thort time, will caule the crop to rot.

\section{SEcr. 2. Breed of Cattle-bow fur improved.}

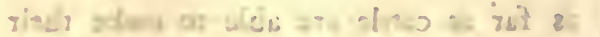

THERE is very little variation in the breed of black cattle, and efpecially in the mountainy parts of the county. They are of various colours and Shapes, ibue generally fmall, as heavy ftock could not fubfift upoo the fcanty fare of our mourtaips, being principally 
joung heath, or beder, a common name for heath with the natives, and a coarfe kind of carex grafs, which fprings up immediately, after burning the heath, in fpring, which in many parts of the county is a common practice, to the great deftruction of game, bus more particularly groufe.

The common cuftom is, with the occupiers of mountainy tracts, to let the grafs for the fummer feafon, for fo much a beant, or by the fum, according to the country phrafe, to the inhabitants of the low lands.

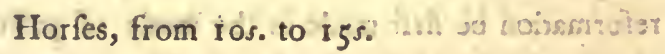

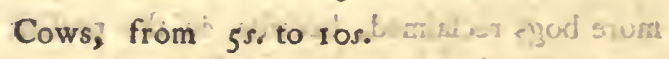

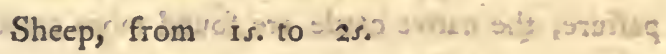

In Glenchordial, between Omagh and Gortin, one of the appendages of the Munterloney mountains, grazing lets, fomewhat higher, it being allowed to be the beft feeding mountain in the county.

At the fall of the feafon, generally in October, great numbers of the horned cattle are killed, and fold in all the country fairs and markets, not by weight, but moft commonly by hand or view, at from 3 os. to 3 h a carcafe. By the country people it is called horfe-beef, becaufe it is carried to market on horfeback. The poorer clafs are the general purchafers, and three of four of them frequently join in a carcare. Some are brought home, and fed on ftraw during the feverity of the winter. 
From this treatment, we cannot expect any improvement in the breed of cattle, fo far as relates to mouittainy pafture, which, indeed, compofes a great part of the pafture of the county, particularly in the baronies of Strabane and Omagh. Many die, even in the fummer months, through extreme poverty, and not a few die of diforders, which, no doubt, proceed from the fame caufe. No pain's are taken to improve the breed of cattle, nor would it anfwer any good purpofe to do fo, till a reformation be firft made in the mode of pafture, and more bogs reclaimed, becaufe, in the prefent ftate of pafture, the native cattle are found more certain, than ftock brought from the fouthern or weftern counties.

Though our milch-cows are far from being well fhaped in general, they are, notwithftanding, commonJy good milkers, to fecure which the people take infinite pains. If a perfon happens on a bad milker, he fells her again as foon as polfible, and fo continues buying and felling, till he finds one to anfwer : this is not attended with much expence or lofs of time, as the fairs are fo numerous and convenient throughout the county.

- The horfes are alfo badly haped, though very durable, and capable of undergoing a great deal of fatigue, upon fcanty allowance. We fometimes meet a better kind of horfes, which the farmers ride and work occafionally, but thefe are generally bought at remote fairs. Fermanagh fupplies this county with fome good cattle. 


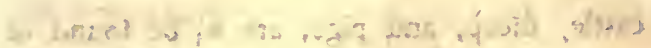

Breed of Cattle-bow far capable of further improvement.

It has been remarked, in the preceding article, that to attempt to improve the breed of cattle, till better pafture be introduced, would anfwer no good end; therefore it is needlefs to dwell on this fubject. Beforê any material improvement can be made in ftock of any fort, a better fyftem of laying down land; with judicious courfes of white and green crops, muft firft take place.

\section{SECT. 3. Markets and Fairs for Cattle.}

PERHAPs there is not another county in the kingdom better fupplied with fairs than this.

$\begin{array}{lrr}\text { In January there are } & \text { II fairs. } \\ \text { - February } & - & \text { II ditto } \\ \text { - March } & - & 9 \text { ditto } \\ \text { - April } & - & 6 \text { ditto } \\ \text { - May } & - & 24 \text { ditto } \\ \text { - June - } & - & 16 \text { ditto } \\ \text { - July } & - & 9 \text { ditto } \\ \text { - Auguft - } & - & 18 \text { ditto } \\ \text { - September } & - & 6 \text { ditto } \\ \text { - October } & - & 16 \text { ditto } \\ \text { - November } & - & 24 \text { ditto } \\ \text { - December } & - & 9 \text { ditto }\end{array}$

- 159 in the year.

Black 
Black cattle, Meep, and pigs, are to be found id every fair, and at all feafons; and in the fummer months, in the principal towns, new-calved cows and fpringers are commonly fold on market days. Sheep are. alfo fold on market days, efpecially of late, fince the army began to be quartered throughout the principal towns and villages.

Both fairs and markets are generally fupplied with she common country breed; but, from Augunt to the beginning of November, a much larger and better fort are to be met with in the principal towns; thefe arc brought from other parts. In May, wethers are brought from the Weft by jobbers, which, in a few weeks, are fold to butchers. This is, in general, a profitable kind of traffic; heep of this defcription, laid in at May for 25 s., will fell out, the Auguft and September following, at from 325 . to 40 s. befides the fleece, which may be ftated at four or five nillings more.

Fairs for horfes are much more limited, than thofe for lheep and black cattle. The following are the principsl.

Strabare.

Nay-confiderable; good cattle, and high pricect.

Dungannon.

Carnteol-confiderable.

Ballygariley.

Onagh.

Cilogker-confiderable, the fummer fair only. 


\section{OF THE COUNTY OF TYRONE.}

Fivé-mile-torun.

\section{Beraugh.}

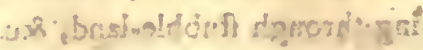

Duninelong - confiderable.

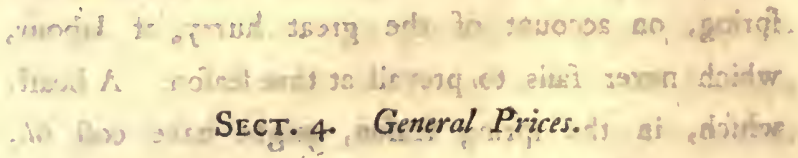

THE price of ftock varies very much, nor can there be any general rule laid down to afcertain this point. Forward feafons, and the ftate of provifions, are the fureft guides to judge by. In very dear feafons, fuch as the years of 1800 , and I 801 , milch cows fold at an immoderate price. I have known fome of the common breed to rate fo high as twelve guineas, the milk being of great relief to the poor in thofe fevere times; whereas, on the other hand, dry cows brought but a low price, though both feafons were very promifing, and turned out remarkably well for grafs.

Times of plenty, and the profpect of a forward feafon, never fail to raife the price of dry cattle. A beaft, fappofed not to weigh more than $3^{\frac{\pi}{2}} \mathrm{cwt}$. (I $20 \mathrm{lb}$. to the cwt.) when made up for fale in November, generally colts from $5 l$. to $6 l$. the preceding May, though in very poor condition. At $3 d$. a pound for the beef, and about 5 os. for the hide and fat, the whole may be fet down at $7 l_{0} 15 \mathrm{~s}$; fo that, from this ftatement; unlefs the beef exceed $3 d$. by the pound, the profit cannot be reckoned fufficient for the fummer's grafs; but 
2 great deal is made of land by after-grafs, and feeding through ftubble-land, \&c.

Common working horfes are always dear in spring, on account of the great hurry of labour, which never fails to prevail at that feafon. A beaft, which, in the fpring feafon, might have colt 6l., probably may be fold, the October following, for $3 l$. This great variation in the price of horfes arifes from the fcarcity of winter food, as very few of the fmall formers can afford better food, in winter and fpring, than oat-ftraw, and the tops of young furze, as has been already noticed.

Common sheep, bought in at May for 15 s., fell, the October following, at from $20 \mathrm{~s}$. to $25 \mathrm{~s}$.; but, this muft be underftood in good low-land foils, and not in mountainy ones; the fleece is generally worth' 3 s. Five fheep are allowed to a plantation acre. "There is more profit on meep and lambs, than on wethers, when the lambs fucceed, which is not always the cafe; the lamb and the wool are fuppofed to be cleared, both worth 2bout 125 .

\section{Secr. 5. Mode of feeding Cattle.}

THROUGHout mont parts of the county, and particularly the beftimproved parts of the baronies of Strabane and Omagh, black cattle are houfed during the heat 
heat of the day in fummer, merely for the object of encreafing manure, and not to guard the cattle again It too much heat, of which there is fcarcely ever any danger, our fummers in general being quite the reverfe. This fyftem is chiefly confined to milch cows, the young ftock being gencrally fent to the mountains, to remain there the fummer and autumn half-year.

As the ftock of grazing among the farmers and la. bourers is feldom abundant, they are very induftrious and careful to pick up every bit of foil they can make out about ditches, \&c. Cabbage-leaves and potatoe-ftalks, as foon as the latter article becomes fit for ufe, ftill help for food and manure, and encreafe the quantity of milk and butter.

For want of good fences to protect the crops, the cattle are alfo houfed at night; this, of courfe, adds to the fund of manure. With me it is a doubt, if the farmers were even pofferfed of fufficient fences, but they would ftill prefer the practice of keeping their cattle houfed at night in the fummer feafon, on account of having an opportunity of encreafing their fund of manure. Still, however, this confideration mould by no means prevent the introduktion of good fences for many ufeful purpofes, which, in this place, it is not my province to dwell upon.

About towns, where fields and parks are in general fecurely fenced by dry ftone-walls or quickfets, cows are fuffered to lie out at night in fummer and autumn, 
and, in favourable feafons, to the latter end of November.

I have often heard this fubject talked orer by the better informed people, whether it be wifer economy to have the cattle houfed in the fummer feafon, as above ftated, or let them remain out altogether. There might be many reafons given for and againft both fides of the queftion; but I believe, by weighing all maturely, that houfing is the beft economy. The other mode, perhaps, in fome inftances, might be found beft, but this mould be chiefly underftood for the neighbourhood of towns; but the misfortune is, that the inhabitants of fuch places fcarcely ever pay the leaft attention to the manure of cattle, 'by collecting it freh, fhortly after it falls from them, 'and before it becomes too dry, which renders it entirely unfit for the purpofes of manure. This neglest is the chief caufe of the numerous rank'and infipid tufts of grafs we meet about towns, and other parts, where this bufinefs is not fully attended to. Some, however, break and fcatter the dung when it becomes dry, but this is of little or no ufe, as it then becomes quite exhaufted, and the rank tufts are not prevented from taking place.

With refpeef to the feeding of horfes, the fame advantage, as far as relates to manure, cannot be obtained, as from black cattle, fince the manner of feeding is more precarious. When not at work, the horfe is generally fpancelled, or tied by a rope to a fake, on the 
road fide; or in fome corner of a field under crop. When at work, fome fcraps of foil are made out for him between working hours, and the fame commonly. at night-time.

Sheep are not ufually fed on the low lands in the fummer feafon; they are generally fent to the mountains for fix months, from the firft of May to the firft of November, but, if the weather fhould fet in fevere, not fo long.

Cattle, bow far boufed in Winter.

The weather points out to the people when to houfe their cattle. In order to fave fodder, which is al ways a fcarce article, they keep them out as long as poffible, or fo long as the weather will permit. Many farmers have their cattle comfortably lodged, both cows and horfes; as to bullocks or oxen, there are but few. In very fevere weather, the fmall fcattered flocks of heep are fometimes looked after, but are moft commonly fuffered to range through the country in common, and many of them are utterly loft.

In very fevere weather, the young ftock of black cattle are collected into fome out-houfes, or fheltered fituations, where they are treated as well "as the nature of the cafe will allow.

In order to fave fodder as much as porfible, the farmer feldom threhes more on one day, than what his 
cattle are able to confume the fame day; this bufinefs is generally performed by the fervant boy on mornings and evenings, before and after his day's work.

Whatever little ftock of hay there may be, is generally referved till fpring, and that chiefly for horfes, who at that feafon mult work very fevere, in order to expedite the fpring bufinefs, which is, in general, very prefling, between oats, barley, flax, and potatoes.

As to the poor cottiers, who generally derive under the farmers of all denominations, their mode of feeding their cows, in winter, is very precarious and uncomfortable; fome, according to the rule of cottake, or cottiers-take, may have half an acre of oats, which commonly produces thirty flooks of fraw, of twelve meaves to the ftook. Such as are fo circumftanced confider themfelves very well off, though this allowance is not more than half fufficient for the feafon, as thirty flooks of fraw feldom weigh more thab 10 or $12 \mathrm{cwt}$., and a ton, of either hay of fraw, is two fmall an allowance for a cow, for the feafon. As hay is generally out of the cot. sagcr's power, he muft buy as much more ftraw as his cot-take produced, otherwife his cow muft ftarve; the average price of Atraw is eight pence a ftook, fo that fixty ftooks, what is fuppofed to have off the cottake, and what he muft buy, may amount to forty hillings; and the fummer's grafs, unlefs mountainy pafture, is commonly the fame. 
But many there are, who are far from being fo comfortably circumftanced as the foregoing. Without any kind of a cot-take, but the bare walls of a cabin, frequently without even a fmall garden, the poor man muft ftruggle through-life; but almoft every labourer is alfo a weaver; when the linen trade is good and provifions cheap, he does tolerably well, fo far as potatoes and oatmeal are concerned, but is generally ftraitened for milk and butter; the latter, indeed, the poor feldom ufe.

As to the manner of houfing in winter, cottiers' cows generally fare better, with refpect to warmth, than thofe belonging to farmers, as one houfe generally anfwers for the family and the cow. Miferable as this circumftance is to relate, it is really fact, and will hold good throughout more than the one third of the pea. fantry of the county.

Till men of property fet fome plans on foot to alleviate the condition of the poor, there can be no chance of improving their fituations; $\mathrm{ky}$ farmers, or under tenants, who are generally underftood to be farmers of the loweft denomination, and are moft com. monly thofe, from whom molt of the labourers, and the pooreft clafs of the weavers hold their cot-takes; what can be expected from a fet of beings, who are for the greater part fully as wretched as the cottiers themfelves? I find myfelf wandering from my fubject, but I requett the reader's indulgence. for a few words more.

A farmer. 
$\Lambda$ farmer, who may occupy ten or fifteen acres, of perhaps bad land, is neither a farmer nor a cottier; he is mucl worfe fituated than a cottager, placed in a comfortable, eafy fituation, immediately under the lord of the foil, with certain privileges, fufficient to fupport himfelf, and family, fo far as relates to potatoes, flax, grazing, and a frall garden, with a little hay, or, for want of it, a certain allowance of fraw; for thefe the labourer can afford to pay a better rent, than the petty farmer is able to pay for his land. By. this fyltem, the landed property will be encreafed, the individual cottier made happy and comfortable; this will excite induftry, will create wealth; and thus the community at large can never fail of benefiting by this mode.

SEcr. 6. Natural grafes.,

I believe all the natural graftes peculiar to the kingdom are to be met with in this county; it is at leaft the cafe, as far as I could learn. Upon this fubject, with the inventigation of other plants indigenous to the county, I have, for fome years back, fpent fome time and fpeculation; the refult of which I hope, one day or other, to fet forth, though I cannot fay, that I hall be able to add a fingle fpecies to the collection at Glaffnevin, according to the catalogue 'I have feen of that collection.

The 
The Fefcue and Poa grafles are the moft numerous in found foils, in which fituations the vernal grafs is never wanting. In rich reclaimed bogs, both fpecies of the white meadow grafs always flourin, though in any foil, newly laid down, they profper for two or three years; but in dry fituations they foon give way to the above, which, with the white clover, moft commonly compofe the principal mafs; but the latter is almoft peculiar to every fpot, which in general fupplies all defects in the verdure of the furface, where clay is at all concerned.

According to the received fyftem, clover is not ranked among the natural graffes; but as many of them fupply the place of the moft valuable graffes, at leaft fo far as relates to pafture, I nall here confider them in the fame light, that farmers ufually do.

A perennial clover, in England commonly called cow-grafs, here known by the name of horfe-hamrock, is frequently met in detached tufts, in ftrong foils, and cold clays. This is a mont valuable plant, and fpreads falt. Seeds-men frequently impofe the feed of the red clover for this article, which they may readily do, as, by barely infpecting the feeds of both, they are not eafily dintinguifhed, at leaft by common obfervers. In this county, in dry feafons, the feed ripens very well; a few ounces of it might be foon collected, which in two or three feafons, by good 
management and clean culture, afford a plentiful fupply. A ftock of pure feeds might foon be procured, by feparating the roots.

'Ihe famous forcen-grafs, already mentioned as a fubftitute for green food, I muft in this place make a few more remarks upon.-

- In making roads through our moft fpongy and worn of bogs, we frequently find this fpecies take place naturally, in the courfe of two or three feafons, in the bottoms and fides of water-tables and ditches, and along the footways, between the gravel and the edges of the fences. Upon fcouring thore drains and ditches in fpring, and cafting the fuff with the mangled grafs in queftion upon the furface of the bog, we find a ftrong permanent foil foon formed. But I find, where this work has been performed carly in autumn, that the good effects of fivarthing over fooner take place. The reafon is plain, becaufe a dry fummer, following the fpring operation, prevents many of the roots from Atriking anew. Thefe obfervations, which are really fact, shew clearly, how much this femi-aquatic grafs might be turned to our adrantage, with little trouble or expence. I have frequently known this grafs to fhoot upwards of twenty feet in a feafon, and produce plenty of roots at every joint, which are always numerols; but in rich bogs, the joints are further apart 


\section{OF THE COUNTY OF TYRONE.}

than in barren bogs, but the whole fummer's growth, in the former cafe, together with an uncommon degree of Juxuriance, is always found moft confiderable.

Great advantages might be derived from timothy grafs, by encouraging, and confining it to the foil it is beft calculated for, and where other grafles of greater repute, though perhaps not defervedly fo, would not fucceed. It is not common; fometimes, however, we meet it in ftrong, four, clay foils, commonly in detached groupes, in which fituations the feed, in favourable feafons, comes to maturity.

Some years ago, I got a confiderable quantity of this feed from America, and fowed it upon a very ftiff clay. foil, which retained water almoft perpetually, and was fo fituated, that draining was found to be of very little ufe; yet, notwithftanding, the grafs flourithed, and is at this day as pure and as free from other graffes, as the firft year after the feed had been fown, which is fo far back as the year of 1792 . The foil is now perfectly dry and firm, though no fubfequent draining, or any other improvement of the furface, had fince taken place.

It is very fingular, that I never have been able to fave any perfect feed from that procured from America, though I have perfectly fucceeded in raifing perfect feed from the native growth.

Bulk for bulk, the feed of this grafs weighs heavier than any of our natural grafes. 
It was formerly in great repute in England, from whence it found its way to America, where, I am told, it is confidered as one of the moft valuable graftes in that country. When better known here, I make no doubt, but it will become a favourite alfo. For working horfes it makes excellent food, but I find it is not over favourable to the dairy.

\section{Sect. 7. Artificial Grafes.}

Except red and white clover, I cannot find, that any artificial grafres have been attempted in this county. White clover is fometimes fown feparate, but moft commonly mixed with red clover; but very little of either is raifed in the county, by way of artificial graffes; the former foon covers the furface without being at the trouble of fowing, and the latter we commonly find in patches, in dry, wholefome foils, and fometimes mixed with the perennial red clover, or cow-grafs, and frequently accompanied with the common trefoil; fo that there are four fpecies of clover, generally ranked as artificial graffes, frequently found growing fpontaneounly together, perhaps within the compars of one fquare yard; nor is it uncommon to find more kinds of clover within the fame fpace.

Mr. William Rofs, of Strabane, defervedly merits great applaufe, for his Rkilful management of red and white clovers on a deep bog, which had been cut out.

The 
The principal top-dreffing was foaper's-wafte. This ufeful citizen has hewn many proofs of his knowledge and good economy in farming and irrigation, or watering of meadow and grafs lands, in the vicinity of Strabane.

\section{SEcT. 8. Mode of Hay-making.}

THE fmall lap-cock, of about ten or twelve pound weight, made up green is the common practice of the county, and alfo of the greater part of the North of Ireland; experience having taught the people, for many years, that the large grafs-cock, generally followed through many parts of the kingdom, is by no means the mode fuitable to this county, and particularly in wet feafons, which are too frequently fo at the feafon of the year, that hay is ufually made up here, being feldom earlier than the firft of September, except in new laid down upland, moft commonly in the vicinity of towns, where manures can be fpared for meadows. In fuch fituations, from the beginning of July to the beginning of Auguft is the ufual time for hay-making; but in all cafes of managing hay harveft, this work is never attacked early enough by the common farmers, who are not under the controul of gentlemen, or of fuch as are better informed than themfelves. There is one reafon, why the farmers permit their hay-grafs to re- 
main fo long before they cut it; it is this; about the beginning or latter cnd of April, their ftock has confumed the whole of the fodder, the meadows are therefore kept open and grazed, until near the beginning of June, a bad practice; confequently were the farmer to cut the hay, earlier than the latter end of Auguft, or beginning of September, the crop would be very fcanty, thefe months being reckoned for the growth of grafs.-Remedy-Let the farmer proportion his flock to the quantity of fodder he may harc, which I believe is very feldom the cafe.

When I firn faw this method of hay-making practifed in this county, I muft confefs, I thought it moft abfurd, trifling, and tedious; but I was foon convinced to the contrary, from a little experience and local knowledge.

The firf thing to be done, after the hay is mown, is to go over the fwarth, and collect any weeds that may be, which at that time is eafily done. In low-land meadows, ruhes and fprit are generally the articles molt injurious to hay; and, as thefe are always longer than the grafs, they projcet fomewhat beyond the bulk of the fwarth, and may be readily felected from it: Both runes and fprit make good thatch, and as that article is always fcarce, great pains are taken to collect them for that purpofe. But when rufhes and fprit are not over abundant, the farmers are not anxious to collect them, but le: them mix with the general mafs; fome benefit 
accrues from the addition of the fprit, bit none at all from the rufhes, which dwindle away, before the hay is brought into the haggard.' Indeed at beft hay of this defcription is only fit for dry cows, and a running ftock of black cattle. Rufbes are not fo good for thatch as fprit, the latter being tubulous, and of courfe better calculated to difcharge rain water than the former, which is pithy.

In collecting the prime part of the grafs; after being mowed, for hay-feeds, much attention is fometimes paid; but this can only take place in the firft or fecond crop, after the land has been laid down; for future crops yield but very little feed. The white meadow grafles are always moft prevalent, and are moft fought after. In new laid down grounds of almolt every defeription, the white meadow graftes generally predominate, for the firft and fecond feafons, and fhoot longer than the other graffes, which gives an advantage in feparating them from the general mafs, as they project beyond the bulk of the fwarth. Of this difpofition thofe, who wilh to colleet the feeds pure, avail themfelves, before the fwarth be broken ont or fcattered. It is tied up in fmall heaves, and placed to dry like flooks of corn, till the feeds are ripe, and fit to threfh out. So much for economy with refpect to faring grafs-feeds, but to return :

The great art, in making hay from natural grafes, is to break out the fwarth thoroughly, by hand, and not by the lazy way of torfing it about with forks, asd 
fitcks, as is the cafe in the great hay countries in moft parts of: the kingdom. Sometimes the fwarth is fuffered to remain for a day, before it be broke out, and fome let it remain longer; but fuch, as underftand this bufinef's perfectly, break out the fwarth immediately after the mowers, be the feafon dry or wet, unlefs the latter prevails too much, in which cafe the mowers are, of courfe, ftopped.

In good weather, grafs; cut in the morning, is made into lap-cocks in the afternoon, unlefs it be very heavy forced grafs, in which cafe more time muft be allowed, and frequent turnings. The feafon always determines the fize of the cocks; in good weather, they may be about eighteen inches in the bafe diameter, but confiderably lefs in broken weather. When the weather is yery much broken and unfettled, which is, indeed, often the cafe, the cocks are made hollow, fo as to re. femble a lady's muff, which: figure has the power of turning the rain, befides admitting a thorough paffage for the air.'

If the weather be favourable, the hay will be fit, in a few days, to make up into large cocks, generally about half a ton. It rarely happens, however, that hay can be got up thus fuddenly, as the feafon for mowing natural meadows feldom takes place before the middle of Augurt, and, too frequently, not till the firft of September, when, moft commonly, the autummal rains greatly retard this bufinefs; in this cafe, the - litile 
little lap-cocks have always the advantage over every other fyftem of liay-making.

It is amazing to find, what Mavery and hardnip thofe cocks will endure, before they are materially injured. I have frequently known them to remain a month together in the lap-cock ftate, and, after all, to have fuffered very little.

The whole fecret is, in making thofe cocks fecure at firft, and forming them into an even convex, to turn the rain with the greater eafe, and frequently changing their fituation, without breaking the firft thape given to them, whilf the grafs was green and frefh. If ever the furface be broker, after the lap-cock is firf made from the frefh grafs, the hay will furely fuffer in bad weather. It is the incruftation, which the freh grafs foon acquires after being formed into lap-cocks; that fecures the whole, and in which lies the whole fecret; and this thews how neceffary it is to lap the hay as foon as poffible after being cut.

In the hay-yard a rick is preferred to a cock, as the expence of thatching is lefs; and, when hay is not cut, but pulled, there is certainly lefs wafte in a rick. $\cdots$

\section{Obfervations.}

A prejudiced notion almoft univerfally prevails throughout the county, and, I believe, through moft parts of the North of the kingdom, namely, that natu- 
sal meadow, fuch as is fituated along brooks and rivers, \& c. Should not be mowed till after the dogdays, which may happen earlier or later in the feafon, but are generally confidered to be between the ift and 2oth of Auguft. This obfervation may fometimes hold good, but it very frequently happens that, immediately after the dog-days, wet weather commences; befides, the oat-harveft ufually takes place about this time, or a little after, fo that both works interfere at once, which, of all things, Mould be avoided as much as poffible, as, in cafe of both meeting, the one mult certainly give way to the other, and, by fuch bad management, one, or, perhaps, both, are materially injured, or, at beft, got over in a lovenly manner.

- By being contented with one-third lefs hay, and taking a proper advantage of the feafon, fo as to have the other two-thirds fecured, before the prefs of the oat-harveft hould take place, would be found by far the beft cconomy.

The above evil arifes from the fodder being confumed fo early in the fpring, which obliges the people to let their cattle have the run of the land, intended for meadow, perhaps to the firft of June. Green food, in the fpring feafon, would moft effectually prevent this difagreeeble circumftance. 
SEct. 9. Dairịes-their produce.

As far as I can learn, there is not a dairy in the county, for the public fale of milk and butter.

The produce is chiefly milk and butter, as very little cheefe is made, except a little for family confumption, which is of an inferior quality. Butter, in the fummer feafon, is to be had frefh in every town and village, moft commonly at a dear rate, fometimes fo high as a fhilling a pound of eighteen ounces. It is a common practice with huxters and dealers, to reduce the pound of eighteen ounces to fixteen ounces (the ftandard), before they retail it to the public. This is a grievance, which might be eafily remedied by the firft fellers, by making their pound only fixteen ounces, fince they alone are the fufferers, and not the confumers.

All the butter, the farmers can fpare in the fummer, is generally made up for winter and fpring ufe; the produce of the county is generally confumed within itfelf. The maxim of the common people is, to live on buttermilk in fummer, and referve the butter for winter; this is certainly good economy, but it is not literally followed.

Such part of the milk, when churned, or what is commonly called butter-milk, is can be fpared from 
the family, is generally fold to labourers and poor weavers, commonly at one halfpenny a quart in fummer; and befides, the butter-milk is generally adulterated with water, with which the poor people mult difpenfe or want. Many farmers are, however, very liberal in beftowing part of the butter-milk to the poor.

Vaft numbers of calves are reared throughout the county, which is the principal caufe of butter bearing fuch high prices; a fecondary caufe is, the army ftationed through the principal towns.

\section{Objervations.}

In countries, where milk and butter fell at high rates, there is no mode, by which a farmer could make more money, than by keeping a public dairy, or rather fupplying cows, for that purpofe, to a dairy-man.

In many parts of the kingdom, the farmer fupplies the dairy-man with a certain number of cows, at fo much per cow, from the firft of May to the firft of November; and, if a cow thould not prove to be 2 good milker, the farmer muft fupply a good one in her place. It is a fettled point between the parties, that cach cow munt give fo many quarts of milk in the swenty-four hours, diminihing, of courfe, as the feafon. 2dvances. 
Five guineas a cow I confider a price for the feafon, by which both parties might have very ample profits. This ufed to be the price fome years ago about Drogheda, when milk and butter were cheaper than at prefent. But, in order to make this fubject fomewhat intelligible, I thall fuppofe five guineas a cow to be a medium throughout the kingdom.

For this purpofe good grafs, and changes of pafture, fhould be kept up by the farmer; this, from the nature of the contract, muft neceffarily follow.

I hall fuppofe the cows bought in the beginning of May at feven guineas, and fold out in November at five guineas; in this cafe there is a lofs of two guineas, but the dairyman pays the farmer five guineas, which leaves a clear profit to the latter of three guineas. Now as there muft be good grafs kept up, as already obferved, I hall fet down three acres againft two cows, which thews the farmer to be paid two guineas an acre for his land; and, in cafe his rent be twenty millings an acre, it is clear his profit muft be very confiderable, even allowing for loffes incident to all cattle. This immenfe profit may thus be made, without fcarcely any expence attending it.

I thall ftate the dairyman's return as follows, which I confider more under than over the true ftatement, which, in this inftance, cannot be accurately afcertained. 
One pound of butter a day, for fix

$$
\text { E. s. } d \text {. }
$$
months, at $9 d$. 6166 Twelre quarts of butter-milk, as ftated for butter, a day, at $4 d$.

$$
\text { - } 3 \circ 8
$$$$
£ \cdot 9 \quad 172
$$

Deduct five guineas, $\quad 5 \quad 13 \quad 9$

I thall fuppofe the number of cows to be

$6 \cdot 4^{\circ} 3$
twelve; -

One man, and two women, to attend the dairy, I Shall fet down at -

$-\frac{2000}{6.3010}$

The farmer's return on twelve cows, 36

guineas,

Dairy-man's return,

$$
\begin{array}{r}
40190 \\
-3010 \\
\hline 610180
\end{array}
$$

From the above ftatement it appears, that the farmer's profit is more confiderable than that of the dairy-man; but, upon the other hand, the latter runs no hazard, for, if a cow moold die, or meet with an accident in the freld, he is not to be the fufferer.

The farmer has another advantage; he may make fomething of his land, in the winter months, by meep, and 2 runaing ftock of black cattle. But the great 
point, in favour of the farmer, is, how much his land will be improved by following this fyftem.

It muft naturally occur to thofe, who might be inclined to purfue this fyftem, that the vicinity of towus would be found moft eligible, on account of the vaft number of labourers and tradefmen, who live in fuch places, without having any means of keeping a cow; as, of courfe, all the town-parks muft be occupied by the wealthier part of the inhabitants.

Sect. 10. Prices of Hides, Tallow, Wool, and Quantity fold.

HIDEs.-This article varies very much with refpect to price. In times of war, hides are always higher than in thofe of peace. Though this fact may appear ntrange, from the great quantity of beef, that mult be exported in the former cafe, yet fo it is, and always holds good. From this it muft be inferred, that war encreafes the value of leather to a confiderable degree. The price alfo differs according to the weight of the hide; one weighing eighty pounds may coft at the rate of 40 s. by the hundred weight; when another, of feventy pounds, may colt only $35 \mathrm{~s}$. by the fame weight. The tanners have rules to go by, according to particular weights. A cow-hide fells generally higher, weight for weight, than that of a bullock. 
The rcader will pleafe to obferve, that I mean green or undrefled hides. 'The hide of a horfe fells for very little; it is ufually bought by hand, 5 s. or $6 s$. being the ufual price for the hide of a middle-fized horfe. Forty fhillings a hundred (112lb.) is the medium price for the hides of black cattle in general. Calf-rkins are generally fold by hand, from $3^{\text {s. to }} 5^{\text {s. }}$ It is impoffible to ftate, with any degree of accuracy, the number of hides fold in the feafon, funce the fkin of every beaft that may die is difpofed of, whether by a regular courfe of flanghtering, or by accident, or diforders. Some years, cattle fall off in greater numbers by diforders, than in others. The profpect of a fcarcity of fodder caufes a greater number of cattle to be llaughtered, than would otherwife have been the cafe.

Though there are a great number of fmall tan-yards in the county, both in towns and country, yet a vaft quantity of tanned leather is annually brought from Dublin to all the principal towns. The Dublin leather always fells for a higher price than that manufactured in the county. Soine ycars ago, a great deal of leather ufed to be fent to Dublin and elfewhere, but this practice is now almoft given over. The great fcarcity of tanner's bark is likely to bring the tanning trade into difrepute. At prefent, almolt all the bark ufed in the county is imported. Mr. Hamilton's wood, in Munterloney, for many years back afforded the principal fupply 
fupply of bark, but at prefent thofe woods are nearly cut down.

Great encouragement mould be given for raifing birch and black fallow, for temporary relief; the price of the bark of birch and fallow is half that of oak.

Tallow.-There is lefs variation in the price of this article, than in that of the former, as foap and candles are uniformly ufed, both in this and the neighbouring counties, which alfo contribute to regulate the price of tallow.

Tallow at prefent bears a good price, as it has done for fome years back; the medium price is 31 . per hundred, (of I $12 \mathrm{lb}$.) though it is fometimes fold by the long hundred (of I $20 \mathrm{lb}$;) but either modes make no difference to the feller or purchafer, as the price by the pound is always underftood. If candles rate at $g d$. a pound, tallow ufually fells at $6 \frac{x}{2} d$. per lb. and foap in proportion, but the latter is not fo high as the former, at leaft the common foap is not, but bleacher's foap is dearer than the common fort.

The quantity of tallow fold depends upon the num. ber of cattle killed, for fuch as die through poverty produce but very little tallow.

Soap-chandlers are but few, but manufacturers of candles are in every town and village. No regular accounts are kept of the quantity of tallow, or fuit bought in, fo that it would be found impoffible, in this place, to form any accurate ftatement of the quantity annually fold. 
As far as I can learn, the county is fufficient to fupply itfelf with foap and candles.

Wool.-Sixteen fhillings a fone may be confidered the average price for wool, for the laft ten jears; i6lb. being ufually allowed to the none. By retail wool generally fells at from $14 \mathrm{~d}$. to $18 \mathrm{~d}$. per pound.

The county is by 'no means eminent for theep, and fuch as they are, in no great quantity. Simall fattered flocks are to be met with, in the mountainy parts, in fummer, which in winter, are difperfed through the low-lands, without any diftinction, fo is not to be confined to any particular diftrict; for at that feafon, a kind of run-deal, * through many parts of the county, (and particularly the baronies of Strabane and Omagh) takes place, for want of good fences. If the owners know the number of their meep, and have fome private mark on them, by which they may be able to diflnguinh them froin their neighbours', they give themfelves no further trouble about them. In heavy fnows however, every perfon endeavours to collect his little flock to his habitation, but in this they are often difappointed.

From the precarious manner, in which theep are bred in this county, and as the owners of them gene-

rally

* Ran-deal, or run-deal, is a term ufed, when feveral par. ties are joined in a town-land, or part of it, without any permanent mearing. Cattle in fuch fituations graze in common, but the crops are divided only by a narrow margin, of about 2 foot broad, left unploughed. 
sally manufacture the wool for their own ufe, it is impoffible to form any calculation as to the quantity fold. In every fair-town, large quantities of wool, from the weft of the kingdom, are to be met with, during the greater part of the fummer feafon, of which no regular entries are ever made, as it is in a great meafure fold by retail.

The wool of the country, and all that is brought into it, is chiefly made up into cloth, blankets, and druggets. The farmers, who are in general linen-weavers, confume the greater part of the cloth, and blankets; the druggets are worn by the poorer clafs of women; the cloth is generally yard wide, and of a very good quality. The people are all expert in dyeing for their own common purpofes; they dye various colours, but blue is their favourite.

The labouring part, and the pooreft of the weavers, provide themfelves with coarfe cloth, or rather frize in the country hops; they fometimes buy a cloth called ratteen, which commonly wears well. In the Shops alfo, the poorer clafs is principally fupplied with coarfe blankets and ftockings, which are chiefly manufactured in Connaught. The county of Donegal fupplies large quantities of coarfe ftockings. 


\title{
CHAP. IV.
}

\author{
FARMS.
}

SECT. I. Size of Farms.

THE fize of farms differs very much throughout the county; mountainous farms are generally of great extent, and are feldom divided in themfelves, or eren from each other. It is common for feveral perfons to be concerned in one town-land, in the way of common, or run-dale, as it is ufually called; each perfon to pay a proportion of rent, fuppofe a fourth, or a fifth, as the cafe may be; this determines the quantity of land each is to cultivate for his own part; but the cattle run in common, and the number, to the fhare of each perfon, is alfo deternined by his proportion of the rent.

This fyftem is attended with many inconveniencies to the land-holder, and is the greateft impediment to improvements. There is no emulation for draining, enclofing, 
enclofing, liming, or carrying into execution any permanent improvements, as long as this fyftem exifts, fince none of the party have any divifion, which may be properly called their own. If one perfon fhould be difpofed to improve, another, or perhaps the whole party, may be averfe to it, and thus the bufinefs of improving the farm is dropped altogether.

Among the many claufes in leafes, one to oblige tenants to divide their farms inuft certainly be of ufe. I believe there is a law in exiftence, with refpect to mearings, which backs an active tenant, if he thould be difpofed to make up his part of the mearing, though his neighbours fhould be againft it. I fee no reafon, why an active, enterprifing man, who may be concerned in the run-deal fyftem, fhould not have the law to fupport him, as that relative to mearings.

Wherever divifions have taken place among tenants occupying fuch tracts, improvements are very confpicuoufy gaining ground, and efpecially in cafes of long leafes, or when the tenant has an affurance, that his land will be let to him again, at a reafonable rent, at the expiration of his leafe.

The low lands of the eftates of Newtown-fewart and Aughentaine, the property of Lord Mountjoy, are in general well divided, and in many parts well planted with thorn quicks, and timber trees. Farms vary in 
fize from five to fifty acres, and they are much greater in the mountainous parts.

In thofe eftates for many years back, leafes of no more than twenty-one years could be given by the two laft proprietors; yet, notwithftanding, the tenants went on with fpirit and induftry, in the improvement of their farms; this they did, from a confidence they had in a good old modus, namely, that their land would never be given away to another tenant, fo long as they were able and willing to pay 2 reafonable raifed rent; this confideration has had alfo a good effect, with refpect to dividing the town-lands into fubdivifions, fo as that each individual knew his own part to a certainty. It is now in contemplation to give leafes of lives and thirty-one years, which, no doubt, will be found a more powerful inducement for the tenants to improve thcir farms, than the prefent fyftem of twenty-one years.

As a fpecimen of the induftry of the tenantry of the Newtown-ftewart eftate (confifting of near twenty-four thoufand plantation acres) perhaps in this place it may not be improper to ftate the following fact, which I can vouch from my own kuowledge.

From 1795 to 1799 , both years included, it is well known, that the difpofitions of the yeomanry of the kingdom were but very little turned towards improvements, at leaft by far the greater part of them; yet within the above periods, I have given, from the nur- 
feries at Rafh, upwards of one hundred thoufand forelt trees, to the tenants of the eftate, principally oak, ah, alder, birch, fycamore, and mountain an. The greater part of the above were planted in the faces of new ditches quick-wife, and generally mixed with thorn quicks. The timber trees were in general four years old, being two years tranfplanted, and always cut clofe after being put iato the ditches. A trufty experienced perfon from the demefne always fuperintends this bufinefs, to fee that the plants be fecurely bedded, moulded, \&c.

I mention this circumftance, in order to thew, how little the people of this part of the county were tainted. with bad principles. Since the troubles ceafed, however, they have more than doubled their diligence, in every fpecies of improvement within their fphere.

The connty may be faid to confift of three degrees of farms. The greater part of the baronies of Dungannon and Clogher are compactly divided, from ten to forty acres, and the fences are in general good. Farms of this defcription never fail from being of the moft general ufe to the community, becaufe the middleman* is molt commonly out of the queftion, in farms of this defcription.

The next degree of the fize of farms is that frequently beyond the reach of the holder to manage, or

make

* The middle-man is rext the landlord, who lets the land to under-tenants at a rack-rent. 
make the moft of, by fair labour or induftry. Hence arifes the baneful practice of taking in under-t pants; no matter how poor, or of what character, provided the middie-man gets his rent; but in this he is frequently difappointed, and often little lamented. Thofe wretched under-tenants work the land by repeated cropping, till it is capable of yielding no more; they then generally run away, with whatever fpoil they can make, moft commonly a year's rent.

- There are fome inftances however, where the middle-man may be of more general ufe to the community than the landlord. If the former be poffelled of a long lucrative leafe, his intereft in the foil may be better than that of the latter; in this cafe he will find it his intereft to deal reafonably with fteady under-tenants. A lord of a foil, which perhaps he never faw, nor intended feeing; with a receiver, who may be alfo a ftranger to every kind of country bufinefs, and whofe knowledge is confined to that only of receiving rents, and contriving the beft ways and means to augment them; are not the moft likely perfons to promote the general welfare of the community. For this county, it is very fortunate to have but few, if any, of that defcription.

The third degrec of farms are commonly too fmall. Though this fyfem is not altogether fo deftructive to the land as the former, yet it is a bar to a regular courfe of indultry. The man, who holds a few acres, 
perhaps of bad land, can make no figure as a farmer; his fituation as a labourer, with a comfortable cottake immediately under the lord of the foil, is much preferable, having no difficulties to encounter, nor being under any difagreeable anxiety.

SECT. 2. Farm-boufes and Offices.

THERe is much more attention paid to dwelling: houfes throughout the county, than to the offices belonging to them. In many parts, the dwelling-houfes are built with lime and ftone; but by far too many are built with clay-mortar as a cement. In the angles of the houfes, jaumbs of doors, \&c. lime-mortar is commonly ufed, in order to frengthen the walls; but, notwithftanding, the walls frequently bulge outwards, wherever clay-mortar is concerned.

In the barony of Dungannon, many houfes are built of clay, or what they call mud-walls, but, in general, in a lovenly manner, by no means equal to the mudwall houfes we frequently meet with in the county of Dublin. When mud-wall houfes are well built, they are much warmer than houfes built of lime and ftone; they are not, however, adapted for this county, as the clay is not well calculated for the purpofe of building; but the principal caufe is, that they confume too much 
much fraw for thatch, \&c. on which açcount they leften the quantity of manure, a practiçe we nıould always gtard againf?.

Walls of ftone houfes are generally built too narrow to fupport the roof, and efpecially when the mixed cements are ufed, that is, partly lime-mortar, and partly clay-mortar. The fide-walls feldom exceed twenty-two inches in thicknefs, and the end-walls about two feet. The fide-walls fhould be two feet four inches at bottom, and reduced to twenty-two inches at top, which is generally at the height of feven or eight feet from the furface. The battering, or reduction of the thicknefs of the wall, fhould be all on the outfide, and the infide face thould be perpendicular; an inch of battering, to every foot in height, is not too much. This is the moft effectual means to prevent the walls from bulging or fpreading. The fame precaution hould be ufed in houfes or cabins, when the roof is hipped, or half hipped; but, through the county, the gencrality of houfes are built with thorough gables.

There are fome Mated houfes and offices to be met with in fome parts of the county, which, from appearances and other circumftances, are likely to encreafe. The few already built fufficiently prove, what faving there may be in the article of ftraw, one-third of which, I dare fay, is applied to thatching throughout 
the county; but, if nating became once univerfal, this quantity would, of courfe, go to encreafe the fund of manure.

Mode of repairing Houfes and Offices, wbether by Landlord or Tenant.

THE repairing of houfes and offices generally falls upon the tenant; there are very few inftances to the contrary; hence we find buildings in general fo much out of repair, or repairs done fo flovenly.

Where the tenures are but hort, and renewals at all precarious, it cannot be expected that the occupier will be at any great expence, in point of building or repairing houfes; his only object muft be, how to make the molt he can of an uncertain tenure.

All the covenants, that may be entered into at the taking out of mort leafes, are of little or no effect with refpect to buildings. If there are buildings, the enforcing the keeping of them comfortable, or in any kind of decent order, is out of the queftion; a thoufand excufes will be made out by the tenant for nonperformance, and the landlord has no remedy left, but to turn him out, and, in doing this, he has a chance of lofing part of his rent, and, probably, may meet another not better than the former.

There are only two effectual means of fecuring comfortable buildings, and, in fact, to have any degree of 
juftice done to farms; namely, long leafes, or, a certainty of the occupying tenant always having the preference given to him at the expiration of a hort leafe. The fyftem of giving long leafes (fuppofe thirty-one years, or three lives) is certainly the beft mode in this county, as there is feldom found that degree of confidence between landlord and tenant, which in England has been fo happily experienced for ages back, and, in all probability, will be the cafe to the end of time. How happy would be the fituation of thoufands of our yeomanry, were they upon the fame footing of many of the Englin, in point of good underftanding between party and party, or landlord and tenant?

In many parts of England, a good old rule is punctually obferved, namely; one-third of the produce of a farm for the lord of the foil; one-third for wear and tear; and one-third for the cultivator of the foil. Here we have but few inftances of this equitable mode.

In England there is nothing more common, than to have no leafes at all between parties, but only to go on from year to year, and raife the rent occafionally, as the nature of the cafe may be, or thall be found agreeable to the parties concerned.

Sect. 
Sect. 3. Nature of Tenures.

I TAKE for granted, that the information, required on this head, chiefly alludes to cottiers, and the poorer clafs of farmers. 'Tenures, refpecting the better clafs of farmers, I hall referve for the article, General fate of Leafes.

The tenures of the cottiers, who derive under the farmers, and are by far the moft numerous of the labouring clafs, are in general very miferable, though the greater part of them are weavers, but do not purfue that trade regularly.

The cot-take generally confints of half an acre of oats; half a rood, or twenty fquare perches of flax; from half a rood to a rood of potatoes; grazing of a cow; moft commonly a miferable cabin, and bog privilege for turf, from twenty to forty kifhes, and fometimes a fmall garden. Five pounds a year is generally paid for the above. The farmer ploughs the land for oats and flax, and fometimes puts out the dung for potatoes; and, if he gives the manure, the cot-take is feldom lefs than five guineas.

The general rule is, that the labourer pays the farmer in work, inftead of carh; and the latter is fure to make his bargain fo, as that the fpring and autumn 
feafons mult be the times of payment. Many of the farmers are weavers of the firft rate; thefe are fuch as keep three or four looms in their houfes, and have poorer weavers alfo at work for them; in this cafe, the latter generally pay the former the amount of the cottake in weaving; moft commonly, part is paid by weaving in the winter feafon, and part by common labour in the feafons already mentioned.

Sect. 4. General State of Leafes.

TwENTY-one year leafes are mof prevalent throughout the large eftates; there are, however, many leafes of other defcriptions, but very few lefs than twentyone years, except bifhop's leafes.

In trarelling through the country, the lands, held under long leafes (fuch as thirty-one years, or lives, which I confider long), are eafily diftinguifhed from thole of fhort tenures, from the advanced fate of the improvements, fo confpicuous in the former. But this obfervation only holds good, where no third perfon is in queftion, which, indeed, is too often the cafe, as fuch part of the land, held under rack-rent, can never improve, fo long as it remains fo circumftanced.

A large portion of the county is bifhop's land, fub. ject to various modes of renewing leafes, but all of 
Mort tenures; yet, notwithftanding, we find farmers very comfortably fettled in well-built habitations, and frequently with fome planting about them. This chiefly arifes from the punctuality of renewing, and, probably, from the lands not being over-let, and that the progreflive rife is more regular and uniform than in other cafes. But this obfervation is very limited; it holds good fo far as the tenant holds a complete farm from the birhop, fufficient only to fupport himfelf and family. By far the greater part of bifhop's lands are rented by gentlemen, and opulent farmers, in large tracts; hence, of courfe, the third perfon muft ftep in, whofe fate muft, in general, be more deplorable, than when circumftanced under other cales of rack-rent. In this there can be no redrefs, on account of the Mortnefs of the tenure; whereas, in cafe of an undertenant deriving under the fecond perfon, with a long leafe, he may have fome chance, becaufe this fecond perfon has a good intereft in the foil, perhaps a better than the lord of it, which has been already obferved.

There are inftances of bifhop's interelt being purchafed; I do not know, how far this may tend to alle. viate the diftrefs of the third perfon; it depends, in a great meafure, on the humanity of the purchafer.

From hence it is evident, that the improvement of bihop's lands can never keep pace with their properties, except upon a confined fcale, as has been re- 
marked. Glebes, unlefs fuch as are wholly impropriate, have no better chance than bifhop's lands.

\section{Of particular Claujes in Leafes.}

It would be found an endiefs tåk to enumerate all the claufes, inferted in the leafes given by the different proprietors of the county. Almoft every man of landed property has his own particular claufes. Thofe in common are the following.

1. A referve to the proprietor, and his affignees, of all manner of game, and other royalties, mines and minerals, as coals, quarries of all forts, fprings, water, water-courfes, turbaries, and all timber, whether over or under ground.

2. Covenant to do fuit and fervice at manor-court, and to grind corn at manor-mill.

3. To join with neighbouring tenants to make fufficient fences.

4. To make new ditches, and plant trees and quicks.

4 5. To permit landlord to fearch for mines.

6. Not to alienate or mortgage, under penalty.

7. To oblige tenants to reftore to the premifes all dung made thereon.

8. To exhibit and prove lives in leafes, to exift at ftated pcriods. 
Innumerable other claufes might be named; but there is one in particular, which, in my opinion, fhould be fcouted altogether, at leaft from the generality of leafes. This is the claufe, which binds the tenant to fupply duty men and borfes, and other dues, too fhameful to mention. Men and horfes are always exacted at bufy feafons, which muft ant againft the tenant. The lors of a few men and horfes, in a dormant feafon, might not be much felt ; but this is not the object of the landlord, becaufe cutting and drawing home turf, corn, \&xc. are the works principally laid out to be performed by duty.

I have had many opportunities of obferving the effects of this kind of duty, and, on the whole, I am certain, that the landlord is rather a lofer, than a gainer, by this kind of dealing. A dinner, and plenty of whinkey, are generally given upon thofe occafions; and, when it is confidered how little work is done, the balance will mont commonly be found againft the landlord. The tenant is generally bound to give fo many men and horfes, and he will take care to come as late in the day as he can, and work as little as poffible for the remainder of the day: with him a day's work is the object, and the lefs he does, he looks upon to be the better for himfelf. In fome cafes, the tenants are bound to perform duty upon a different footing from actual day's work: the landlord muft have his works, as fpecified in the leafe, performed by the tenantry in 
common, according to the rent they pay; but, let the obligation, or the mode of performing this bufinefs, be as it may, it is always attended to with the greateft re-. luctance. The fooner this feudal relick is abolimed, the better it will be found for all thofe concerned; though I am not without apprehenfion, that many of my readers, will not join me in opinion.

Inftead of filling up leafes with poor infignificant claufes, which anfwer no fubftantial end, fome good fart lutary claufes might be introduced; fuch as binding the tenant, under a fevere penalty, to drain, enclofe, lime, marle, \&c.; alfo, to attend to certain courfes of green and white crops. Such are the claufes, by which both parties would foon find benefit; and with which, on a certainty of reafonable leafes, tenants would chearfully comply.

\section{Sect. 5. Taxes or Ceffes paid by Tenants.}

THE taxes are; cefles for the fupport of roads, bridges, \&cc. The cefs for roads is laid on the barony, to which they bclong; other ceffes on the county at large. Though thofe taxes are fometimes confidered a grievance, yet, in general, they are paid more chearfully than any other fpecies of tax, both on account of the benefits the public derive from roads and bridges, and alfo the advantage the circulation and return of money is to the tenantry of eftates, who are 
always the executers of the public works; fo that the money they pay returns back to themfelves.

Hearth-money and window taxes are always confidered a grievance among the poorer clafs, and are frequently paid with murmur and difcontent, as their ideas are, that no future advantage can derive to them for money fo laid out; they never confider, that fuch taxes are for the fupport of a government, which protects them and their property.

There are other taxes fettled by aces of veftry, for the repairs of houfes of worhip, paying fextons, \&cc.; but thefe affect the indiviáual, only in a very fmall degree.

SECT. 6. Proportion of working Horjes or Bullocks, to the fize of Farms.

WITH refpect to the proportion of cattle to the fize of farms, there is no fixed ftandard or rule. A farm of twenty acres may require as many cattle to cultivate it, as another of fifty acres, according to the quantity of arable land the farm may contain. Few bullocks are made ufe of. Except in large farms, two or three horfes are about the number ufually employed. Very little ploughing is performed till after Chrifmas, of courfe the fewer cattle are neceffary. Drawing turf and manure occupies more time in the year, than ploughing. Occupiers of fmall farms generally 
lend and borrow horfes, to and from each other, and efpecially when the farmer has but one horfe, which in fmall farms is frequently the cafe.

SEcT. 7. General fize of fields and enclofures.

Frelds and enclofures vary according to circumftances. In the vicinities of towns, they are generally fmall, from one to five acres and upwards.

The nature of the fituation is frequently (or hould be) 2 guide for the fize of enclofures; expofed afpects require enclofures to be fmall, the better to fecure fhelter, and wet fwampy land muft be always improved by fmall enclofures; at leaft the expence of draining is leffened. Thefe are points, pretty well underftood by the generality of the farmers of this county.

Upon a great fcale, the beft improved parts of the county, with refpect to regular and ufeful enclofures, are the greater part of the baronies of Dungannon, and Clogher.

Between Omagh and Drumquin, for two or three miles from the former; and from Omagh to Dromore; and alfo from Omagh to Fintona, may be fet down in general, as being well divided, and in fome parts planted with quick-fet, but very few foreft trees. The farmers throughout Lord Mountjoy's eftate, chiefly in the barony of Strabane, are making rapid ftrides in 
point of enclofures, generally fmall, from one to fix acres; and very few enclofures are formed, without: being planted with thorn quicks, and timber trees.

About Cooks-town the enclofures are very regular, and jodiciounly laid out in town-parks, and upon an. extenfive fcale, which, with many other ufeful and extenfive improvements, reflect the greateft honour on. the late and prefent proprietors.

Sect. 8. Nature of Fences.

THe nature of fences varies with circumfances, or locality of fituations.

In mountanous fituations, where ftones are plenty, dry walls, badly built, are commonly made ùfe of. Where culture is in queftion, this mode ferves two ends, namely firft, by clearing the land of ftones, and fecondly, for fences to divide it; on this account, if the ftones be found very numerous, the enclofures are made fmall, and the walls very thick, at bottom fometimes four feet, and commonly four feet high. 'This the farmers confider a cheaper mode, than that of drawing part of the ftones away altogether, in which they are perfectly right when over-ftocked with ftones, which in thofe fituations is ufually the cafe.

- When ftones are not found fufficiently plenty to form dry walls, fod-walls are introduced, fometimes

When 
with a fone foundation; the fods are laid edge-ways, and built about four feet high, and fometimes topped with furze. Such perinable walls require to be renewed every fecond or third year, but this is not confidered expenfive, as the old fods mixed with dung, and fometimes lime, anfwer extremely well for manure for potatoes, and fometimes as a top-dreffing for grafs-land.

Bogs and fwampy fituations are generally divided from arable land by large drains, fo as to divide the fummer pafture, and confine the cattle to the bogs at that feafon; but this mode is chiefly confined to fertile bogs, as fpungy quaking bogs are feldom acceffible, except in very dry feafons.

The mode of fencing by common ditches is in general very bad; they are fo ill built, that they frequently tumble down the firft winter after being built. The dimenfions are always too fmall, five feet wide, and three feet deep, for the gripe is the general fize; of courfe, the bank mult be very poor. For want of an off-fet, ${ }^{*}$ the thorn quicks, if planted at all, are left quite bare after the firft winter, and too frequently little pains

*An off-fet, or fearcement, (the latter is the country phrafe) is a fpace, which fhould be left between the verge of the gripe, and the face of the bank, from fix to twelve inches, accord. ing to the nature of the foil, or the polition of the ditch. 
pains are ever taken afterwards to afford them any relief. About towns however, we fometimes meet with good hedges, which are better attended to than throughout the county at large: this is owing to the narrow fcale townfpeople are generally concerned in, and the neceffity they are under of fecuring their fmall concerns, on account of the high rents they ufually pay. Though about towns they never attend to the leaving of a fcarcement, they notwithftanding, by patience and perfeverance, get up the hedge through time; if the ditch hould Alp or give way, which indeed is almont always the cafe, they patch up from the bottom of the gripe, with fods, ftones, \& cc. to meet the quick.

Hence it is plain, that for feveral years there muft be perpetual trouble and expenfe, whereas a reafonable fcarcement would have faved both.

When I come to treat of Lord Mountjoy's improvements at large, the article, fences, thall be fully treated of, according to the different modes, which were found neceffary to be adopted in thofe extenfive concerns.

Mode of bedge-rows, and keeping bedges.

Hedge-rows are rarely met with in this county, and the few, which occur, are but flovenly managed. In molt cafes they are let to run at random; without taking 
taking any pains to manage the trees, by directing their heads to the right or to the left, fo as to affift the quick-fet with a free circulation of air; which is a fecret our people know nothing of. In fome cafes the trees have been lopped too feverely, and in many inftances have been pollarded, to the great deftruction of the timber.

In fhort there is very little attention paid to the old timber, in hedge-rows, fcarce as it is. I hope however, it may not be the cafe in future with the young growth, as moft of the farmers and others, who plant, have got into the habit of planting quick-wife, moft commonly mixed, with thorn quicks, inftend of planting tall, aukward, and ill rooted fandards at the backs and tops of ditches, where they are always expoled to cattle and other infults and accidents. As to the keeping of hedges in a neat, garden-like order, cither by fquare or taper clipping, it is quite out of the queftion, except in fome particular places, fuch as about towns, and fome few farm-houfes of the firft clafs; but all are attached to the old mode of cutting hedges, which caufes them to be always bare at bottom. Hedges are feldom cleaned more than one or two feafons, after being planted, and then are left to chance.

The precarious manner of procuring thorn quicks, from Dublin, very often of a bad quality, and almoft always materially injured, by being too long out 
of ground, with bad packing, and at the mercy of indolent carmen, muft be always a bar to this improvement, but of this I Mall fpeak more fully in another place.

\section{SECT. 4. Nature of Manures.}

UNDER the article Mode of Culture, I have made fome remarks on common manures, to which I refer.

With refpect to mixed manure, (a kind of compoit commonly made up of common dung, mud, or mire, backs of ditches, fcrapings of ftreets and roads, and other materials, fuch as can be collected, and fometimes lime) the farmers and cottiers of this county are not inferior to thofe of any part of the kingdom. The abundant crops of potatoes to be met with, in all parts of the county, are convincing proofs of what induftry is ufed in the various ways and means of collecting manures, becaufe without manures, in our very beft foils, there can be no chance of fecuring a tolerable crop of potatoes, and the mixed manures are always found the beft, and if a little lime can be added, it is found fill better; but lime alone, without being mixed with other materials, is not found to anfwer for potatoes in moft cafes; but there have been inftances of ftrong old leas, when early ploughed, and roche lime turned in, producing 
cing large crops of potatoes, without any additional manure. To anfwer this end moft effectually, the beit feafon to plough in the lime is July or Augunt, and let the land remain in that fate till fpring, when it fhould be ploughed again, and well harrowed, the better to mix the lime effectually.

The practice of burning moory foils, and rich black bog, is univerfal throughout the county, nor did I ever hear of any caufe of regret from purfuing this fyftem, which in this county is very ancient. Excellent crops of potatocs are generally procured by this mode, and that frequently without any other additional manure. Dung and compoft, however, are molt frequently mixed with the afhes, and fometimes lime, as, in this cafe, corn crops are certain to fucceed after potatoes, at leaft one good crop, which would be found uncertain, haid the potatoe crop depended upon the alhes alone.

No manure operates more powerfully the firft feafois than anes, nor is there any fpecies of manure lefs abiding.

Manuring meadows by irrigation or watering, is finding way falt through many patts of the county. From the trials, which have been already made, and the great benefits refulting from them, there is every reafon to hope, that this falutary fyftem will fhortly become general.

Confidering how rich this county is in limeftone, yet lime, as a manure, is upon a limited feale. Binding cloufes 
claufes in leafes would, no doubt, remedy this in fome meafure. If inftead of the forry lime-kilns, commonly called pot kilns, which we find fcattered through the county, fubftantial draw-kilns were introduced, there would not be the leaft danger, but that lime would foon become a univerfal manure. For many years back, I have had roche lime, from ten pence to thirteen pence a barrel, of thirty-fix gallons, whereas it is a well known fact, that the farmers, in general, pay from one Milling and eight pence, to two hillings and two pence, in their peddling way of working their pot-kilns.

A lime-kiln of what I call the compofite kind, or that compofed of partly an inverted cone, and partly a cylinder, is certainly the beft confruction. The beft in the ' county is at Rafh, defigned feveral years ago by the late bifhop of Clogher, which conftruction has fince extended to other parts of the kingdom. The dimenfions of the kiln at Rah are as follows: the conical part eight feet high, and the diameter at bottom about eighteen inches; the cylindrical part of the fame height as the cone, making altogether fixteen feet. The diameter of the cylinder, and of courfe the largett diameter of the cone, is eight feet. 'I he fuel ufed is turf, and, when well attended, it will turn out about fifty barrels of roche lime, in the twenty-four hours. There is a lime-houfe attached to this kiln, of forty feet by twenty, height of the walls fourteen feet; it is Mated, and colt in the year 179 I fixty guineas. The kiln was built feveral years 
before, and colt fifty-fix pounds. If built at this time, they certainly would come higher. Were I to build another kiln, and that my fituation could afford it, I would prefer twenty feet, for the whole height, to fixteen feet, or I would rather have the cylindrical part eleven feet, and the conical part nine feet.

A kiln of this defcription, when well attended, might afford lime fufficient for perhaps thirty or forty farmers of the firft rate. Now fuppofe the whole colt, at this day, might be about two hundred pounds, furely this fum laid on forty large farms, in addition to the rents, could never affect the farmers in any degree, proportionable to the advantages they would derive from always having lime at certain and cheap rates.

In purfuance of an original plan of the late Lord Mountjoy's, a large lime-kiln and lime-houfe are now building in a central part of the eftate of Newtown. ftewart, the object of which is to fell lime, to the tenantry of the eftate only, at a reafonable price, not exceeding fourtcen pence a barrel. This cannot fail in obtaining the defired ends, namely, in enabling the tenant to lay on more lime than what he could, in other refpects, ever have any chance of doing, and of courfe in raifing the value of the landed property. The good effeets, which may arife from this mode, cannot be doubted; they are already fufficiently proved by a fimilar practice, followed for feveral years back by a. neighbouring gentleman, Mr. Stewart of Stranorlar, in the county of Donegal. 
Marle is rather fcarce in the county, particularly in the baronies of Strabane and Omagh; nor do I find it is a favourite object of the farmers, though I have experienced wonderful effects from it, feveral years ago, in the demefne of Rahh, on a dry foil.

Many parts of the baronies of Dungannon and Augher abound with lime-ftone gravel, yet I find it is not ufed in any proportion, equal to what it fhould be.

Sect. IO. Mode of Draining.

OPEN drains are in common ufe, only temporary to fave the crops in moift fituations, when the latter end of the fpring happen to be wet.

The fecret of hollow draining is very little underftood in any part of the county, much lefs the intercepting, or cutting off fprings. Sod drains are not known in the county.

Some farmers, in forming ditches, take advantage of the fituation of the ground, fo as to anfwer a double purpofe, namely, that of enclofing and draining, but this fyftem is by no means purfued fo fully as might be withed for ; it is however gaining ground.

Though, in point of conveniency and regularity, the following the courfes of fprings with ditches, fo as to 
anfwer the purpofe of both enclofing and draining, may be confidered an aukward manner of difpofing of the fields aud enclofures, yet, in wet and expofed fituations, it Mould be preferred to any regular mode, for the following good reafons. Firf, draining the land is confiderably, if not wholly diminimed, by the act of enclofing : fecondly, fhelter is rendered more complete, by following the natural and meandering courfes of the fprings: and, thirdly, when thofe ditches are planted with foreft-trces, the fhelter is not only more complete, but the whole fpace, as far as tho improvements are carried on, appears a folid body of planting from many points of view.

By attending to thofe natural circumfances, and planting a few trees in the interfections of ficlds, which might, be always done at very little expence, both beauty and profit would always be the reward of the proprietor.

In general, attention is paid to the draining of fertile bogs, fo far as they are connected with, or lie convenient to arable land. In fuch fituations, immediately at the junction of the bog and arable, the foil fcarcely cver fails to be rich and fertile, and particularly if the arable rifes boldly over the bog. Draining in fuch cafes is not the great object of the farmer; his aim is manure for his farm, in which he is feldom difappointed. Some more prudently attend to both objects, manure 
-2nd draining the bog below, and, in fuch fituations, natural fprings frequently occur, and are in general eafily intercepted.

When I come to treat of Lord Mountjoy's improvements at large, I fhall have an occafion to enlarge upon this fubject, that being the only part of the county, where this fpecies of improvement is carried on to any great extẹt. 


\section{CHAPTER V.}

LOLITICAL ECONOMY.

\section{SECT. 1. Roads and Bridges.}

ROADS and bridges are generally well attended to by the gentlemen of the county, many of whom are cxcellent judges of fuch public works, and take great pains to have them well executed. Very few counties in the kingdom can boaft of better or more convenient roads; fome parts of the poft road, however, between Monaghan and Strabane are an exception; but thofe parts are intended to be improved. I have accompanied Captain Taylor, fome time ago, on the poft-road between Cmagh and Newtown-ftewart, and then approved very much of the new line he adopted; but fince having weighed this matter well, I am ftrongly of opinion, that the propofed linc mould be on the eaft fide 
of the river, the whole way from Omagh to Newtownftewart. The limits of this work cannot afford to hew my reafons in this place, but, if called upon at a future time, I thall be ready to anfwer; but to return:

Befides the accommodation of the traveller, and the ufe of raads from town to town, to mills, \&c. other objects fhould be in view. The principal are limeftone quarries, and the means of being able to get into extenfive bogs, to carry off bog-timber; which at prefent (and it muft be the cafe for many years) is the chief refource of the whole country, for cabins, loom-timber, and many other purpofes.

No fpecies of improvement could tend more to ferve the community at large than the above; many. thoufands of acres might be limed, which for want of roads to the quarries are given up. The more land is brought into culture, the more difficult it is to get at limeftone quarries, becaufe the carriage of limeftone generally takes place in the fummer feafon. It is univerfally allowed, that limeftone could be procured twenty years ago, upon much eafier terms than at prefent, as at that time very little grain or potatoes were in the mountainous parts, to prevent the carriage of limeftone; hence the great necelfity of making roads, and the fooner the better.

All perfons, whofe property lies convenient to a good limeftone quarry, hould exert themfelves, in having roads conducted, as well as thofe, on whore 
lands the quarry or quarries are. It hould be a gew neral caufe; they thould go further, by cheerfully and unanimouly contributing to put quarries in good working order; firft, by giving a power of keeping them dry, when neceffary; fecondly, by finking fo as to be able to work upon a fair face to advantage, and, of courfe, by being able to get at the beft part of the ftone, which is generally the loweft in all quarries; and thirdly, by employing intelligent perfons, to fee that all be fairly carried into execution. Such a perfon might have the general charge of roads for a certain diftrict, and for dividing and regulating bogs amang tenantry. I fpeak from confiderable experience of the utility of fuch a perfon, and efpecially where there is a large landed property, and a numerous tenantry.

Without an enumeration of fome of the principal quarries, I could not, with any degree of accuracy, point out the feveral roads, that hould be introduced, merely an account of the carriage of limeftone.

The county is rich in limeftone quarries, generally of an excellent quality for land. Here I thall mention fome, to which roads would be found of the greateft advantage.

In the barony of Strabane, between Gortin and Dunnamanagh, is a famous quarry called the Butterloop, fituated between a clufter of the Munterloney mountains, and fome of the firft magnitude in the 
county. The greater part of the limeftone is carried on horfeback in fmall creels, or 'cretes, containing about two hundred weight. Roads to this quarry might be made at very little expence, as the materials are always to be found upon the fpot; and, though the general character of the country for many miles is mountain, yet every mountain has its valley, through moft of which roads might be conducted with the greateft eafe. It would be for the intereft of the county of Londonderry, to contribute to a road leading to this quarry, as that county is rather fcarce in limeftone, in the part of it, which lies neareft to this quarry. Wilmount, within two miles of Dunnamanagh, abounds with limeftone. Roads from this place into the interior parts of the mountains of Munterloney would be found of great ufe.

Near Newtown-ftewart are quarries of great extent, to which roads in fome directions are very much wanted.

Drumquin in the barony of Omagh is rery extenfive in limeftone, and the county for feveral miles around it is deftitute of that article. Roads throughout this whole country would be found of the greatelt advantage.

There are many other valuable limeftone quarries throughout the county, fuch as Ballygawley, Cookftown, \&c.

In my different excurfions through the county, I have remarked (and indeed it is invariably the cafe), 
that, where limefone is moft plenty, there the roads are 'few, and, in general in bad order. Claufes in leafes, obliging tenants to contribute towards making roads to limeftone quarries, under certain rules and reftrictions, might probably be of ufe; but, if not done in a general way, I doubt it would be found difficult to bring particular individuals to comply. I only give it as a hint.

As to roads in general, much expence and ufeful labour might be faved to the public, by farming them; that is, by affigning a certain diftance to one or more perfons to keep in repair, after being firft fecurely made. This mode is followed through many parts of England, and, I find, is now practifed in parts of the barony of Dungaunon with good effect.

Throughout the kingdom, roads and briuges always interfere with the two bufy feafons of the year, namely, fpring and autumn, as thefe are the feafons the judges are on circuit. The labourers, who fhould be employed in tilling the land, and faving the fruits of the . earth, are too often taken up in finihing off public works, before the judges enter the county.

From this circumftance is is plain, that much inconreniency and unceceffary expenfe arife; and too frequently the food of man and beaft is loft, or much damaged, by not being able to attend to it in due feafon.

If the roads were parcelled out into certain diftricts at an annual fum, fuppofe fix pence a perch, more or lefs, as the cafe might require; the farmers, who are 
likely to be the undertakers, would find it their intereft to take care, that their public works fhould not interfere with their private bufinefs, at leaft, fo as not to check the fpring and autumn works. In this cafe they wonld prepare materials occafionally, and have them in readinefs to lay on at every favourable opportunity.* By fuch judicious management much advantage would accrue to the public, and we would feldom find bad fpots in roads, which in the prefent cafe too frequently occur. Road-overfeers, (I mean the under ones) according to the prefent mode, never find it their own private intereft to attack a breach in a road, or fet right a pipe or a gullet, which may have got out of order, or let off water from ditches or water-tables, or to do any other trifling matter that may occur, and which if carly attacked, the coft is nothing in comparifon to the letting fuch jobs lie over from affize to affize.

The farming of roads \&c. would remedy all thofe inconveniencies, becaufe, the moment the undertaker found any thing amifs, it would be his intereft to fet it right immediately,

* Soldiers ftationed in different quarters might be applied to great advantage, to make and repair roads in time of peace; the good effects of which have been long ago experienced in the highlands of Scotland. The farmer by this means might be eafed of the weight of county cefs ; the foldiers would have more pay than ufual, and, what would be found better, his time would be better employed than in the dram thop; the military road, in the county of Wicklow, may ferre as a rule to go by. 
immediately, as the laying out of money in due feafon is always found the cheapelt way of going to work.

It would alfo be found good policy to allow the farmer or undertaker that part of the road, which may lie next to his own land; by which means, he would be the more induftrious to clear his ground of ftones, which to him would be a defirable advantage, and of general benefit to the public, fince the more land is cleared, the greater, of courfe will, be the cxtent of culture.

There is no reafon, why a new road hould not be contracted for in like manner. In all cafes, infpectors are abfolutely neceffary. An active perfon employed in this manner, of approved judgment and fidelity, would do away at once petty road-overfeers, and would not be attended with perhaps one fifth of the expence; as the former might anfwer for a whole barony, at fuppofe twenty pounds a year, which would make only a fmall figure in paying the number of overfeers ufually employed in the fame diftrict.

Contracts of this nature hould not be for a lefs term than feven years, to keep roads in repair; if only for one or twa years, contractors will have no permanent intereft in the work, and of courfe they will not take fuch pains to do it well, as if the terms had been longer. Indeed, the longer the term of contract is, the better; it acts upon the contract or in the fame man. ner as a long leafe does on a farmer, which requires no demonfration. 
How far the country might be enriched by introducing more roads is evident, not only from the ufeful purpofe of cheapening the carriage of limeftone, but alfo the great advantage of being able to procure bog timber at a much cheaper rate than the prefent.

Extenfive bogs we find richer in timber than fmall fcattered patches, and the great bogs invariably afford more bog-fir than bog-oak, the former being of three times the value of the latter. It is alfo found, that timber is in larger quantities in the middle of large bogs, than at the edges; hence the neceffity of making roads quite through them.

I have been often an eye-withefs, to fcenes of ftruggling and great fatigue in getting out logs of timber to the hard land, frequently at the diftance of a mile from where the bog was found. Roads would certainly cheapen this bufinefs, not to mention the many other advantages, that would naturally follow the introduction of them. It is in vain to fet about reclaiming extenfive bogs, without firft forming roads, and making large drains and water-tables. A bog may be drained in fome meafure, but how are hard materials for covering them to be brought in, without roads?

Under this head, I beg it may be underftood, that I principally allude to flat extended tracts of red fpongy bog, moft commonly in a floating ftate, which, of all fpecies of bogs, are the moft difficult to improve; but more of this under its proper head. 
Before I difmifs this fubject, I thall beg leave to fuggeft to the gentlemen of the county of Tyrone a plan, which, I apprchend, might not be attended with much expenfe. They are now in poffeffion of the map of the county, made out by Meffrs. William and Conyngbam M.Crea, in the years 1774,1775 , and 1776 .

Since that time, a great number of roads have been made throughout the county, all of which are ufeful, and many of them materially fo. In order to render this map more complete, $I$ apprehend, that all the roads, which have been introduced fince it was finished, might be furveyed, and laid down upon it. When this part of the work fhall be completed, the gentlemen may go further; a copper-plate might be made out, and a great many impreffions ftruck off. The plate fhould be the property of the fubfcribing gentlemen, and any new lines, that may be introduced hereafter, might be delineated on the plate, and thus have new impreffions made out occafionally.

I am informed, that artifts will agree to make out the engraving, and frike off the maps, by allowing them a certain number for their own emolument. The certainty of this may be eafily known, by applying to any of the eminent print.fellers.

\section{Bridges.}

A great mifake in bridge-building is, that the piers and abutments are not well attended to, in having them 
them funk fufficiently deep. More bridges, pipes, and gullets have given way through this caufe, than through all other caufes put together. In clayey and fandy fituations, the courfe of the river or brook is perpetually changing; therefore too much precaution cannot be taken to guard againft accidents, that frequently arife from fuch caufes. Where the current is rapid, there the more care fhould be taken in finking deep; but fuch fites for bridges thould be avoided as much as poffible.

Every day's experience thews us, that bridges are much more fecure in dead or fmooth running water, than when conftructed on fords, or near them, and efpecially upon the upper fide.

Bridges are, in general, built too narrow. The finking of foundations, centering, and mafon-work, between a bridge of twelve feet wide, and one of eighteen feet, bear not the fame proportion, of two to three, in point of expence; that is, if a bridge, twelve feet wide, Should coft 200l., it does not follow, that one, eighteen feet wide, fhould coft 300 l; this every perfon, the leaft converfant in bridge-building, muft know.

In this county, it is only throwing away public money, to introduce cut-ftone coping on the battlement, as the country people carry it away, and few of the road-overfeers give themfelves any further trouble about it. Stones, placed edgewife, of about a foot bigh, and reaching quite acrofs the wall, are prefer- 
able to cut ftone, as there is no temptation for ftealing the former, and this part of the work comes as cheap as any other part of the battlement; whereas cut ftone cofts from $8 d$. to is. a foot, running meafurement, according to the thicknefs of the wall.

The fide-walls of fmall bridges, commonly called pipes, or gullets, are generally built of lime and ftone: where fuch are only flagged over, this precaution is altogether unneceffary. By finking well, where the cafe may require, and ufing heavy materials at bottom, a dry wall is fully as fecure as a wet one, or that built of lime and ftone, which, from much experience, I know to be the cafe.

There is more foul play and tricks ufed in bridgebuilding, than in making of roads. Mafons find it their intereft to make bad work, in order that the job may the fooner come round again, and common roadoverfeers are feldom harp enough to prevent this fraud; hence the great ufe of intelligent honeft infpectors.

I have, more than once, experienced inftances of the foundations of bridges being undermined, previous to floods, in order that the whole fabric might tumble down; nor have I ever known road-overfeers to be any way active in detecting fuch villainy. Indeed, fo long as overfeers have a double intereft in public works, we cannot expect much fair play, for many of the overfeers themfelves are alfo the executers, and, 
where that is not the cafe, their friends are. I am very far, however, from fuppofing, that all the under overfeers of the county are of the fame caft; many of them I know to be men of ability, and poffeffed of liberal fentiments. It is not the men, who have the charge of public works, that are fo much to blame, but the fyftem adopted, and the partiality, that I am forry to find fo prevalent through the whole county; and the only fure way of preventing this evil is, in my opinion, the appointing of infpectors, and farming the roads.

I have introduced, in the neighbourhood I live in, 2 fpecies of bridge, fome years ago, which I find to anfwer extremely well for a fmall mountainy brook. When the water is low, the whole of it paffes under; and, in times of floods, part goes under, and part over the bridge. 'The paffenger, notwith tanding, is feldom ftopped, as mountainy floods foon fubfide; they feldom laft longer than an hour or two; and, in roads not very public, it feldom happens that any perfon may go that way during the flood; and, in cafe a perfon fhould pafs during that time, if on horfeback, he may ford it; if on foot, there are ftepping-ftones convenient.

This kind of bridge may be built for one-third lefs than in the ufual way, where the fituation may be found anfwerable; and, if well executed, is never fubject to be out of repair: it is only calculated, however, for opens, which are intended to be flagged, inftead of fmall arches. 


\section{STATISTICAL SURVEY}

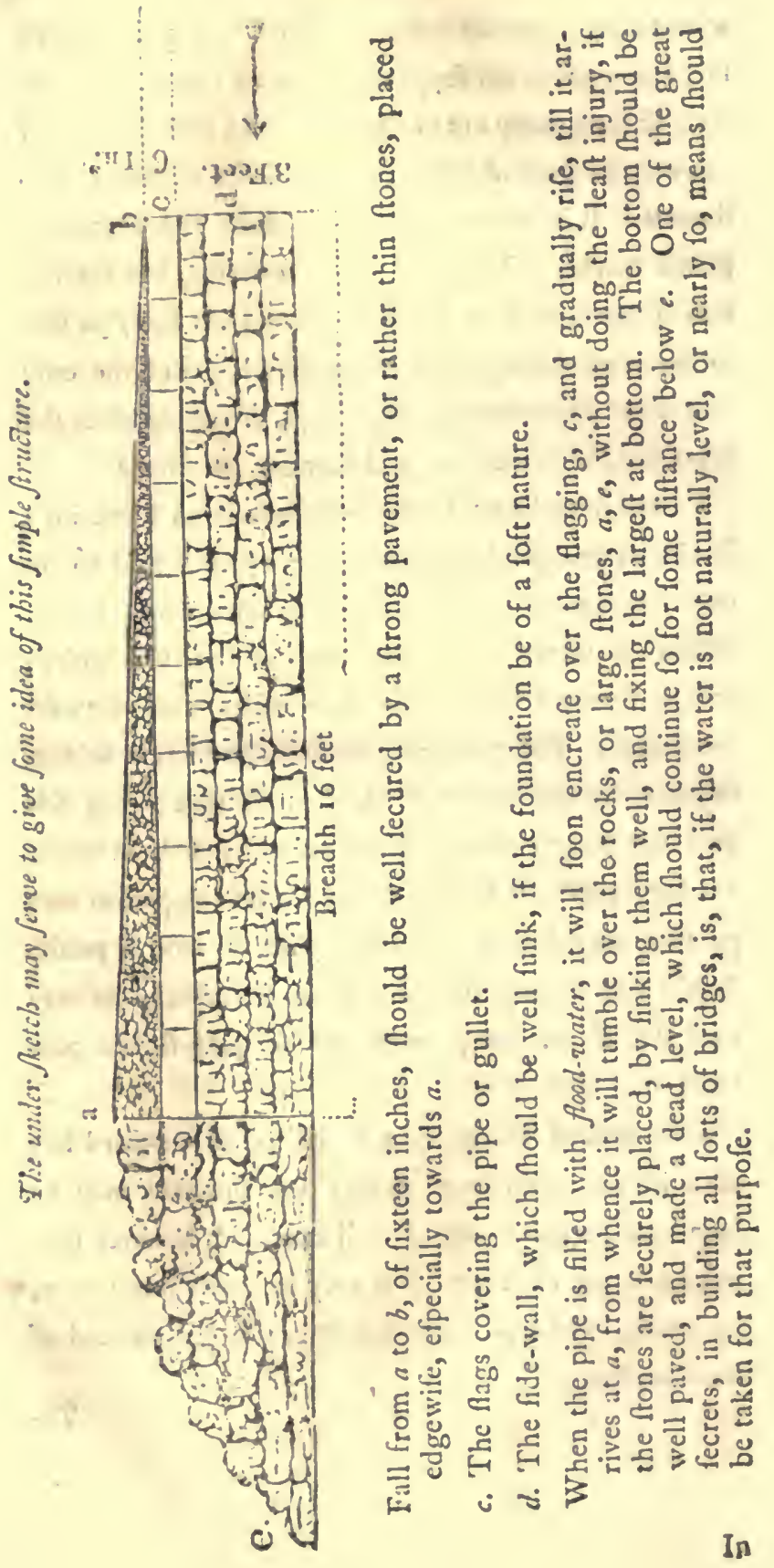


In the fection, acrofs the pipe or gullet, the fhape of the road will appear thus, and give fome idea of the quantity of water, that may be difcharged over it.

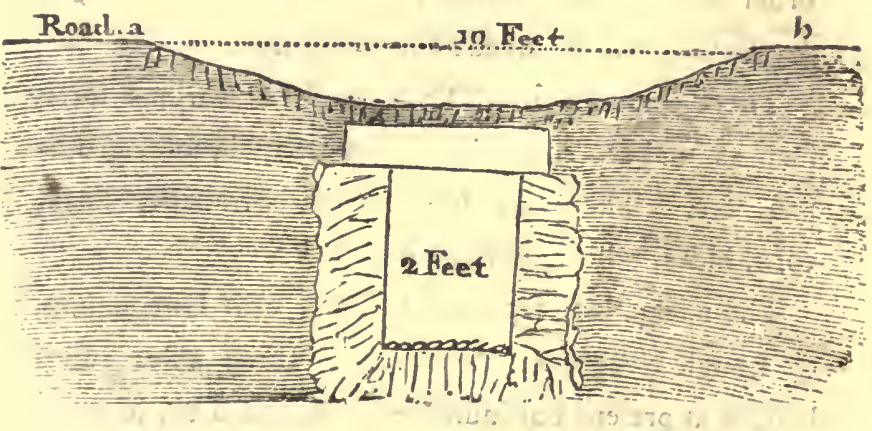

The pipe is capable of difcharging fix cubical feet of water, and the fegment, $a, b$, is equal to nearly ten cubical feet. But there is no neceffity of being confined to one pipe; more may be introduced, if the cafe mould require it, and the excavation made in proportion. Inftead of flags, logs of oak may be ufed, which will laft for ages.

SECT. 2. State of Navigations and Navigable Rivers.

THE navigation from Strabane, for upwards of three miles, where it falls in with the river Foyle, is certainly of infinite fervice to the county, on account of cheapening the carriage of goods of various forts, from

$$
\text { ' } \mathrm{K} 2
$$

Derry 
Derry to Strabane, the whole of the way by water. I underftand, that it is in contemplation to lengthen the canal a confiderable way further down the river, in order to avoid fome hoals and fand-banks, which, in dry feafons, much impede the navigation.

There come up from Derry goods of various forts, fuch as timber, coals, iron, flax-feed, liquors, groceries, \&c. There go down from Strabane, linen, corn, hides, tallow, potatoes, turf, \&c.

The navigation, from Coal-inand, near Dungannon, to Lough Neagh, in length about three miles and a half, is at prefent but indifferently attended to; in many parts it is almoft choaked up with weeds. The chief ufe of this canal is for conveying coals from the colliery. Some timber and other articles are brought up to Coal-ifland, which are difperfed through the country on cars and horfes.

The only navigable river in the county, except the river Foyle, is the Black-water, which runs from Lough-Neagh to Black-water town, diftance about ten miles by water. In this courfe there are two or three Inoals, which require to be removed. The boats are from twenty to eighty tons burden, and bring to Black-water town feveral kinds of goods from Newry (from which town there is alfo a canal to LoughNeagh), fuch as timber, iron, coal, culm, flates, anes, falt, \&rc., and bring back barley, oats, and fometimes 'fotatoes, and alfo linen cloth, as there are two 
or three extenfive bleach-greens in the neighbourhood of Black-water town. Armagh is only four miles from this village, with almoft a dead level the whole way; a canal, of courfe, would be found quite practicable.

A canal, made from Verner's ferry, or from the Moy to Dungannon, both about the fame diftance, not exceeding five miles by land, would render the county of Tyrone completely well circumftanced, perhaps as much fo as any county in the kingdom. A few years have hewn, of what infinite advantage the Strabane canal has been, and is likely to prove to the community. A canal, from either of the above places to Dungannon, could not fail in producing the like effect, fince the country, for many miles about each of thofe principal towns, is nearly alike circumftanced, with this difference, that Dungannon is quite furrounded by bleach-greens, which is one principal reafon for introducing a canal. Situated as thofe towns are, at both extremities of the county, renders them very advantageoully fituated for trade; either of them being within twenty miles diftance of any part of the county, and confiderably nearer to all thofe parts moft eminent for the linen trade. Linens might be at once fent by water to Dublin, to England, or to any other diftant part, inftead of fending them on cars to Dublin, which at prefent is the common mode. Dungannon is at prefent, and has been for many years back, a flourifhing 
town; how far a canal would add to its profperity, requires no demonftration.

I have not fufficiently examined the country about Dungannon, fo as to be able to form any idea of the beft line for a canal, or how far water might be fecured in quantity fufficient to feed it ; but the latter, I conceive, there could be no doubt about, from the great number of extenfive bleach-greens all through the neighbourhood, the wafte water of which muft be very confiderable.

\section{SeCt. 3." State of Fißheries.}

$I$ kxow of no regular fifhery in the county, except that near Strabane, which is confined to falmon. This is immediately under the infpection of the perfons, who rent the royalties of the rivers, which ultimately fall into the river Foyle.

- Though there are fevere fines and penalties againft poaching, or killing of fin unlawfully, yet vant depredations are always committed by idle fellows, who make this bufinefs a great part of their occupation. The molt deftructive way of deftroying fin is, by night, with lighted faggots or ftraw, at the time the falmon are about to fpawn, or emit their young.

Thofe, who pay for privilege of fining, would act well for themfelves and the community, if, inftead of 
paying yearly falaries to water-keepers, as they are called, they would allow them the full amount of the fines fettled by law. I have tried both ways, and found the latter to fucceed completely.

SECT. 4. State of Manufactures, whether encreafing.

THERE is no manner of doubt, that the linen manufacture is daily encreafing, notwithftanding the great number of people leaving the country for America every year, and alfo the number to fupply the militia.

There cannot be a greater proof of the encreafe of the linen trade, than the great rife of flax land. About ten years ago, half a rood, or twenty fquare perches (generally Cunningham meafure, lefs, by nearly onefeventh, than plantation meafure), let at $8 s$. now (in 1802) the fame quantity of land frequently brings double that fum. Another circumftance clearly points out the encreafe of the linen trade: common labourers, who were not much in the habit of weaving fome years ago, generally work out two or three yards of linen at night in the winter time, after the common day's labour is over. I mention this, to fhew'the induftry of the people; and many of this defcription are obliged to work at common labour for their employers in the day time, at leaft for a great part of the feafon.

From 
From a long refidence, and an intimate knowledge of this country, I can affert, that at leaft one-third more land is now occupied by flax, than what had been ten years ago, which is a convincing proof of the encreafe of the linen manufacture; the great rife on linens, of late years, is another. Every day the induftry of the people is gaining ground on bog and mountain, particularly the latter; and it is alfo notorious, that, ten years ago, as much land was taken up with crops of potatoes, oats, and barley, as at this day; this alfo fhews, how much the culture of flax has been extended of late years.

At Cook's-town, a mullin manufacture is eftablifhed, and is likely to fucceed. At Strabane, by Mr. Rofs, corduroys, and other articles in the cotton way, are manufactured to no fmall extent. In the barony of Clogher, much druggets are made for home confumption, but there is no regular eftablifhment. Near Coal-illand, in the barony of Dungannon, and at Fintona, in the barony of Clogher, arc coarfe manufactories of earthen-ware, tiles, fire-bricks, \&rc. In every town, and in many villages, foap and candles are manuiactured, and even in fome country places. 
Of encouragement to them, and the peculiar aptnefs of the fituation for their extenfion.

Some years, back, the Linen Board gave premiums for the encouragement of flax-feed of Irin growth; the practice of fowing Irifh feed, however, has been difcontinued, for reafons known to the growers, who muft be certainly well acquainted with the difference between foreign feed, and that of Irih growth; nor is it likely, that they would prefer paying fuch high prices for foreign feed, if they found the Irim growth to anfwer the main end, which is that of having the good quality of the flax in view.

I do not know of any fcheme, that could tend to encourage the linen trade, more than that of faving of fuel in bleaching. The quantity of turf, that is annually ufed in the county, is moft aftonihing.

I am furprifed, that fome enterprizing bleacher, before this time, has not taken a hint from Count Rumford's fyftem, which could not fail in anfwering the defired end.*

In fome bleach-greens, upwards of 10,000 kifhes of turf are annually confumed, or an area, at leaft equal to I , 000 cubical yards, of made up fuel, fit for confumption.

* At the Linen-hall, in Dublin, an apparatus is fet up for the faving of fuel. 
fumption. Sixty kifhes of turf is a reafonable allowance for a cottier, fo that one bleach-green confumes as much fuel as 166 cots. This is a ferious confidetation, and fhould be an object worthy of the attention of all thofe concerned. I make no doubt, but fursaces, properly conftructed, might fave four-fifths of the fuel confumed at prefent.

The following effablifhed Bleach-greens will ferve to ßbew the prefent fate of the Linen Manufacture in the County.

Names of Bleachers.

Places of abode.

William Shaw, - Caftle Caulfield, near Dungannon.

James Guaherty, Dungannon.

Duffin and Co. - Ditto.

Thomas Rodman, Ditto.

William Grier, - Ditto.

Thomas Grier, - Ditto.

Robert Grier, - Redford, near Dungannon.

John Grier, - - Dungannon.

John Wilcock, - Ditto.

Ditto (two), - - Near Cook's-towa.

Cook, - Ditto.

James Grier, - Ditto.

Thomas Grier, Jun. Ditto.

J. Patterfon, - Ditto.

James Cook, - Ditto.

John Kcnng, - Ditto. 
Names of Bleacbers. Places of abode.

William Anderfon, near Cook's-town.

A. Stewart, - - Coal-inand.

Brown \& Sloane, Ditto.

Thos. Grier \& Co. Ditto.

William Pike, - Ditto.

- Purcel, - Brookfield, near Dungannon.

Jackfpn \& Eyre, Blackwater-town. Thefe have two more bleach-greens adjoining, in the county of Armagh.

John Chambers, Omagh.

- Smiley, - Near Strabane.

- Quin, - - At Duglafs-bridge, below Newtown-ftewart.

- Sproule, - Spa-mount.

With fome others, now eftablifhing, or in contemplation of being fhortly fet on foot.

My information, with refpect to the bleach-greens about Dungannon and Cook's-town, was from Mr. Wilcock of Dungannon, an eminent bleacher.

Some bleach on their own account; that is, they buy the linen cloth. Others bleach for the country, at fo much a yard; but the greater number bleach for themfelves, and for others.

There are fill many eligible fituations in the county for bleach-greens, many of which, no doubt, will Shortly be occupied, from the rapid progrefs of the trade.

The. 
The following fituations, among many others, are commodioully fituated for water, afpect, and fuel.

Three or four, between Lord Mountjoy's demefne, at $\mathrm{Ra} h$, and Newtown-ftewart, on the river Struel.

One at Drumquin, by removing a corn-mill, and placing it a quarter of a mile below the village, where the fall and fituation are much preferable to the prefent.

One or two on the Poa, or Fairy-water, between Poa-bridge and Dodean-bridge.

One above Mr. Chambers's green, near Omagh.

Several might be introduced, along the river between Omagh and Fintona, and from Ballinahatty to near Dromore. The fituations are very good aiong thofe rivers, but in fome parts turf is rather fcarce.

I have already mentioned drugget; here I beg leave to recur to this article, the encouragement of which would be found of the greateft advantage to the lower clars, both as to wearing apparel, and keeping them fully employed, at a feafon when flax may fametimes be out of the reach of the poor.

From the beginning of June, till towards the firft of September, is the moft dormant part of the year for fpinning of flax. The poor people's ftock, or what they generally grow themfelves, is commonly fpun by the firft of June; and the remainder of the feafon, till the new flax comes in, is commonly fupplied by flax purchafed at the markets, or elfewhere. 
The above period, therefore, is that, in which the poor might be, in fome meafure, employed in fpinning of wool, as at that feafon it is generally procured upon cheaper terms than flax. Befides, fummer weather anfwers beft for fpinning wool. A fpinner can manage flax by the light of the fire only; wool requires more regular light: hence the latter is the beft fubject for the long day.

But there is another confideration of great confequence, trifling at firft view as it may appear. The root of the common fern is at this feafon replete with an oily glutinous fubftance, which is well known to make an excellent fubftitute for oil or butter, without which wool cannot be manufactured, unlefs the fernjuice be made ufe of. A pound of wool requires a quarter of a pound of butter, or the fame proportion of oil, to prepare it for fpinning, which may be faved by attending to the exudation of the fern, when cut up in fmall pieces. Perhaps it might be an object worthy of chemical enquiry, to find how long this juice might be preferved, and how to prepare it for that purpofe. So far as I could learn from the common people, the root is cut into fhort pieces, bruifed in a mortar, and then put into a cloth, and preffed out.

I have feen beautiful pieces of drugget, made up in this country by houfe-keepers. When thickened in the tuck-mill, it is warmer, and lants longer than otherwife: in this cafe, two parts are generally compofed of wool, 
wool, and one of Alax; in the ufual way, the wool and flax are equal.

I hope our northern farming focieties, when more generally eftablifhed, will attend to this hint.

\section{Secr. 5. Population.}

Doctor Beaufort's Memoir, of his map of Ireland, makes the number of houfes to be 28,704 . From a great number of views, that I have taken in different parifhes, I find the average of perfons to each houfe rather exceeds fix, which number, by allowing fomething for emigration, I Thall abide by, fo that the whole of the inhabitants may be fet down at 172,224; a great population indeed, which, I believe, is very near the truth. 


\section{CHAP. VI.}

RURAL ECONOMY.

SECT. 1. Prices of Wages, Labour, and Provijions.

SEVERAL caufes affect the rates of wages and provifions. Since the introduction of militia and yeomen, the value of labour has been confiderably raifed. Alfo, when the linen trade is good, the price of labour is fure to rife, as moft of the labouring clafs are alfo weavers. In fpring and autumn, labour is always higher than at other feafons. Labour is always higher about towns than in country places; yet moft labourers prefer the latter, as the jobs are generally long and fteady, and provifions are to be had upon more reafonable terms.

It may appear fomewhat ftrange, that, when provifions are highert, common labour is always found loweft, and efpecially if the linen trade be on the de. cline. Singular as this may appear, it is a fact that is fully known, and the principal caufe is obvious: the farmer, 
farmer, in order to fave provifions, endeavours to get through all, or part of the labouring work, by his own family, which was almont uoiverfally the cafe in the years 1800 , and 1801 .

Tak-work, alfo, makes a material change in the price of day labour, as a good labourer can earn more money by the former than by the latter; of courfe, he will prefer the mode, by which he can make moft.

Farmers generally feed their labourers, and, on that account, the wages are low, commonly fix pence halfpenny a day, except in the time of harvent, when they generally get a milling a day. But by far the greater number of the farmers get their labour done upon a different footing, as the cottiers are obliged to work for them to a certain extent, to pay for their cot-takes; and the farmers are always fure, that the number of days fpecified muft be ferved in the bufy feafons. Sometimes contracts between farmers and labourers are fo made, as to work a certain number of days in each week throughout the year, but this mode is not common.

- Either for common labour or tafk-work, no regular fteady rules are eftablifhed throughout the county, except in lord Mountjoy's improvements, which hall be noted in their proper order, when I come to treat of that place.

The midule prices of provifions for the lant ten years ending December 1.799, may be ftated as follows. 
l. s. $d$.

Oatmeal, a peck of rolb. - - $\quad$ - 10

Potatoes, by the ftone . - - $\quad \circ \circ 3$

Beef in winter, of a bad quality - $0 \circ 2 \frac{t}{2}$

- in fummer, generally good. - $0 \circ 4 \frac{1}{\frac{1}{2}}$

Mutton the year round, from $3 d$. to $0 \quad 0 \quad 4$

Pork, in winter, - - - $\circ \circ 3^{\frac{1}{2}}$

Bacon, - - . - 006

Herrings, by the 120 , from 3 s: to 046

Salmon, from $3 d$. to - - $\circ \circ 4$

but in winter falmon is generally fold by hand, or at fo much a price; but this kind of falmon is of little or no value.

d.

New-milk, in fummer, by the quart _ $\quad$ I $\frac{\mathrm{r}}{2}$

- in winter - - 3

Butter-milk, always bad, and dear. - -

Frefh butter, of $180 z$. to the $\mathrm{lb}$. from $7 d$. to 10

Cheefe generally bad, from $6 d$. to $\quad-8$

The loaf is never in proportion to the price of grain or flour. If the Milling loaf in Dublin be 6lb. the fix-penny loaf, in all the principal and petty towns of this county, feldom' weighs $2 \mathrm{lb}$; all rules and regula-. tions, relative to this bufinefs, are generally overlooked by thofe, who hould put them in force. 
SEct. 2. Habitation, fuel, food, and clothing of the lower rank; their general coft.

There are two denominations of lower sanks, univerfally to be met with.

'The firt comprehends fuch as have finall farms, by far too limited to make out a fupport in any degrce comfortable, perhaps for more than one half of the year, and too frequently not fo much. Many of this clars are under-tenants, or what is commonly called the third man, and fometimes the fourth and fifth, and too often more fteps removed from the lord of the foil. The further the diftance from the landlord, of courfe the greater muft be the poverty of the laft undertaker, as every occupier muft, or is fuppofed to have profit in the land.

The fecond clafs are chiefly cottiers, who frequently derive under tenants, of different degrees, down from the lord of the foil. Many of this defcription are weavers, as well as labourers. This clafs of people are generally more comfortable than the former, as they run no rifque, and have but little to lofe. But the under tenants (commonly called $\Omega$ ky-farmers) are by far the molt miferable part of the community, as has been obferved in another place.

With refpect to habitations, they are in general very bad, and efpecially fuch as are occupied by cottiers, 
who commonly engage only by the year, and from year to year. Sometimes the cabin is built by the farmer, commonly of ftone and clay mortar, and fometimes of fods only. In the barony of Dungannon, fome fcattered cabins are built of mud, or yellow clay mixed with ftraw for litter, but thofe cabins are poorly made up; the roof is generally of bog fir, or bog oak, and thatched with oat or barley ftraw, and fometimes with ruphes and fprit, heath, broom, refufe of flax, \&c.

But the moft general way of building cabins is by. both parties, that is, by the farmer and labourer, in which cafe the latter is allowed fome abatement in the firft year's rent. Sometimes the whole is built by the cottier, and in this cafe a whole year is generally allowed for the trouble and expence of building, which is generally from three to five pounds. We feldom find the cabins of the poor fubftantial or comfortable, and, when built according to the laft cafe, little can be expected in point of either, fince the poor labourer has no permanent intereft, but only from year to year. Hence we find fo many cabins perpetually going to deftruction through all parts of the country.

I have remarked, that a cabin may be built, for from three to five pounds; the difficulty of procuring the roof, of bog timber, is the greateft the builder has to encounter with. The woods of Munterloncy are almoft cut down, which, for many miles round, and for a great 
number of years back, fupplied the country with timber for roofing, cars, and plough timber, with every - other article the country ftood in need of; now the principal dependence is on the bogs, the procuring timber from which in their prefent ftate is always attended with many difficulties. The thinning of Lord Mountjoy's improvements is now beginning to afford the country fome relief, which, of courfe, will encreafe every year; alder, birch, fcotch and fpruce firs, and mountain afh, are the only articics, which can be cut away at prefent, to eafe more valuable timber; thofe articles are from fourteen to twenty years growth, and are well calculated for cabin building, and many other domentic purpofes. Regular prices are fixed for every article fuitable to the country, which fhall hereafter be explained, when I come to treat of the improvements at large; here I fhall only take notice of fuch articles as are commonly made ufe of in cabin building, this being the fubject under confideration.

In the neighbourhood of Omagh, and within a reafonable diftance of the improvements of Rant, a cabin of the following dimenfrons may be built for the under prices. 
$24 \times I_{4}$ feet in the clear, fide-wall 6 feet, 2 gables. f. s. d.

Stone, and clay-mortar, - $\quad$ - I 100

Three couples, or principals, - - 0 i5 0

Three dozen of ribs, - - -

Two wheel-car-loads of wattles, - - $\quad 55$

One brace-tree or beam, to fupport a chimney,

The above articles are procured from the improvements.

Two door-cafes of bog-oak, - - 044 Two doors of foreign ftuff, - $\quad-088$ Two windows, cafes, and glazing, with

lead-light, - - - - - 066

Thatch, I fet down at $\quad$ - $\quad$ - $\quad$ I 00

Labour of roofing, thatching, \&xc. - 0 I5 6.6 7 II

A cabin, of the above defcription, is reckoned in this country a refpectable and comfortable manfion for a cottager.

Fuel._-Turf or peat is univerfal, and to be procured almoft through all parts of the county upon reafonable terms. It frequently happens, however, that, in moft towns, this article is extravagantly high, though fuch towns may be furrounded with bogs. This arifes from a kind of monopoly, as many individuals have ufurped a right to large tracts of bog, which the poor are too often deprived of. This hould be made a fubject of 
ferious enquiry by gentlemen of landed property, in whom the royalties of bogs are mof commonly invefted. Coal is ufed at Strabane and Dungannon occafionally.

I believe, by all leafes, the tenants have no right to more privilege of bog, than a reafonable allowance for their own confumption; notwithftanding that they may have large tracts annexed to their farms, all of which the lord of the foil may difpofe of at pleafure. If, inftead of fuffering tenants to engrofs large tracts of bog, as they ufually do, to the great detriment of the poor, landlords would fet about to quarter and parcel out fuch tracts, and particularly in the vicinities of towns and villages, they would foon experience the good effects of it. In many fituations, the acreable rene would be found to exceed that of the beft arable land in the fame neighbourhood. 'There is a very ftrong inftance of this between Dungannon and Verner's ferry, where there is a very extenfive bog judiciounly laid for fale by the acre, and which, I am told, lets on an average at the rate of two guineas by the acre, and is by no means of a good quality. Here the proprietor makes a good yearly rerenue; the poor are accommodated for many miles round; and, by the good manner of cutting out the bog upon a regular face, great future benefits may derive from mcadow and pafture.

General Cof.-The colt of fuel depends, in a great meafure, on the difance it is to be brought, as the price 
price of horfe-labour is always high, feldom lefs than half a crown a day.

Sixty hißhes is generally the allowance for a cottier, the kifh being equal to a cubical yard, but it is generally heaped as high as it can be conveniently carried, and efpecially when the turf is of a light fpongy quality. The ufual price for cutting, and making up ready for burning, is 14 s. by the hundred.*

$$
\text { f. s. d. }
$$

Forty kilhes, being confidered equal to a

$$
\begin{array}{cccc}
\text { hundred, }-\ldots- & - & - & \text { I } 0 \\
\text { Drawing, at ten turns a day, } & -0150 \\
\hline \text { 6.i } 160
\end{array}
$$

The above is pretty near the average of the country parts of the county; but, in fome towns and villages, the cafe is very different; the kifh is feldom lefs than Is. Id., and often, in winter time, fo high as $25.8 \frac{x}{2} d$. Regular modes, of parcelling and dividing bogs, can alone eafe the inhabitants of towns of this grievance, at lealt to a certain degree, as numbers of the townspeople would find it their intereft to cut their own turf, and, confequently, the poorer clafs belonging to

towns,

* A hundred of turf is equal to forty wheel-car-loads, or 120 丹ide-car-loads. Twenty clamps, eight feet long, four feet wide, and fix feet high, tapering to the top like the roof of a houfe, are equal to a hundred, and in which ftate they are generally fold; the meafurement to be fettled in four days after the clamps are made. 
towns, who might not be able to cut turf, might buy upon cheaper terms, when the bulk of the inhabitant: were in the habit of cutting for themfelves.

Ford.-Potatoes and oatmcal are the chicf articles, which compole the poor man's food the year round. In the fevere years of 1800 and $180 \mathrm{r}$, large quantities of barlcy-meal were ufed, without which half the people munt have ftarved. Before thofe periods, barleybread was quite unknown.

The poorer clafs cannot afford to ufe much butter, bcing obliged to fell the greater part of it, in order to purchafe neccilaries, which they want, fuch as foap, candles, tobacco, falt, \&c. In fummer and autumn, milk is chiefly ufed; the remainder of the feafon, herrings are moft common with the poor.

Sometimes a pig at Chriftmas may fall to the lot of a family, but this is not often the cafe, unlefs potatoes are plenty. Two or three labourers frequently join in purchafing a cow in November, which generally colts $6 l$, and in return get $2 l$. for the hide and tallow.

The general prices of food are given in the pre. ceding fection, to which I refer.

Cloäthing. - Although a good deal of woollen cloth is made up by the farmers for their own confumption, yet a fmall portion of it falls to the lot of the lower clafs. Common frize, bought at the country thops, is the general cloathing for the common labourer, at leaft for the coat and great coat. This frize is chiefly 
brought from Connaught; here it is coloured or dyed according to fancy, but blue is the favourite colour of all clafles. 'Tickens, cheap corduroys, \&c. are commonly worn for waiftcoat and breeches.

The women common!y wear druggets and coloured linen for coat and petticoat, and the cloak is generally of fome cheap Shop-cloth, chiefly of a grey colour, tho' they affect fcarlet, when they can afford the price. 'The young women are fond of yellow and green ftuff petticoats. Shoes and ftockings are only fecondary confiderations; on Sundays and holidays, and going to fairs and markets, they are always worn by the women, both young and old.

General Cof.--Some years ago, cloathing was confiderably cheaper than at prefent.

$$
\text { f. s. } d \text {, }
$$

A middle-fized man will require 8 yards of frize, or any other narrow cloth, for a coat, waifcoat, and breeches, - 0188

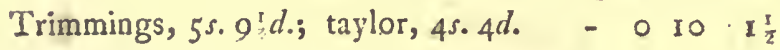
Two Rirts, Ios.; hoes 5 s. $6 \mathrm{~d}$; ; two pair of ftockings, 4 s. $8 \%$. - $\quad$ - I 02 Hat, two years, $3^{s .} 3^{d}$. $\quad-\quad \quad \quad \quad-0 \quad$ I $7 \frac{\frac{x}{2}}{4}$ Great coat, two years, $16 s$. $\quad-\quad-080$ $6.2 \quad 18 \quad 7$

It is feldom the cafe, that a labourer, or even a middle-rate farmer, is thus comfortably cloathed at once; 
the abore, however, may ferve as a ftatement, which is tolerably accurate, according to the prices in 1800 and 1801 ; but I fhould be ftill nearer the truth, were I to add another pair of coarfe fhoes or brogues, which would bring the expence to $3 l .4^{s}$. $1 d$. inftead of 21. 18 s. $7 d$.

Womens' cloathing is alfo confiderably higher at prefent, than was the cafe fome years ago. Drugget, which formerly fold at is. a yard, now fells at I s. $4 d$., and, when ftriped, a penny or two-pence more in the yard; but, in this ftatement, I fuppofe the drugget plain.

f. s. d.

A middle-fized woman will require eight yards for coat and petticoat, - - 0108 Making up, - - - - - 022 A grey cloak, - - - - - O II 8 Making up, - - - - - 0 I I Shoes and ftockings, - - - - 056 Other wearables, - $\quad$ - $\quad$ - 060 6. I $17 \quad 1$

If the coat be of cotton, and the petticoat of quilted ftuff, the price will be higher; and, if the cloak be fcarlet or crimfon of the cheapelt forts, it will ftill add to the expence, perhaps up to $2 \% .5^{5}$. or $2 \%$. 10 .

Farmers" 
Farmers' fervant-girls appear very fmart on Sundays and holidays; and, at fairs and markets, linen or cotton gowns are common with this clafs, and petticoats and fhort cloaks of the former, which they contrive to fpin for themfelves, after complying with the takk they are obliged to perform for their employers.

The induftry, with which this clafs apply themfelves, is molt worthy of praife; they are generally obliged to fpin a dozen of two-hank yarn in the day; befides fome drudgery in the houfe; yet they make out time to fpin a little for themfelves weekly, which in the feafon amounts to fomething, fo as to afford them fuch wearables, as have been already mentioned, with other neceffary articles. Inftead of doing a little for themfelves daily, and in order that the wheel might be always fully employed, the ufual mode is, to give up five days clofe application to the employer, fo as to fpin fix hanks in that time; the fixth day is their own.

From this account, an active girl may fpin for herfelf fifty-two hanks, or dozens of yarn, in the year, which may be rated equal to fifty-two yards; nor is it uncommon to find numbers of this clafs, who are equal to this induftry, and fometimes more.

It has been hewn, under the article Extent of Culture, that a family, confifting of fix, would confume, in the feafon, 


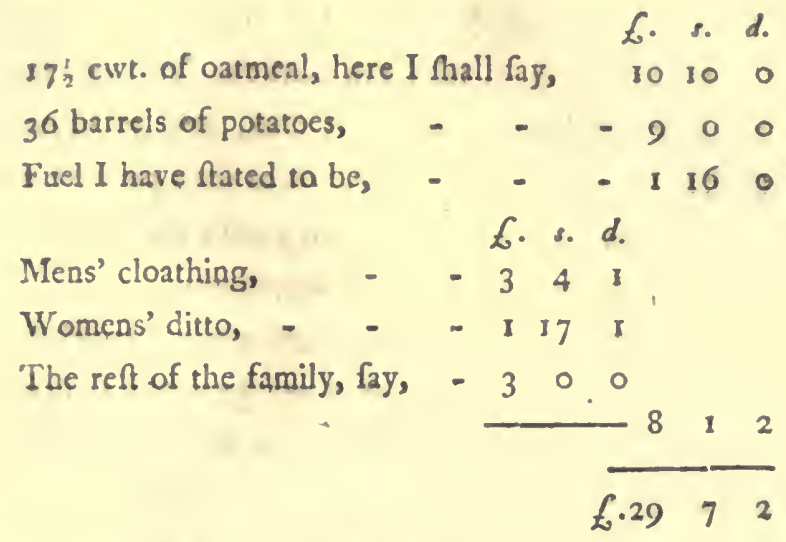

The drawback for the cot-take, in point of provifion, may be thus fated, after deducting fome allowance for feed.

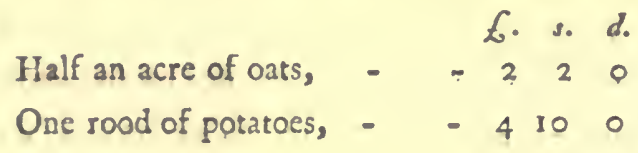
6120

$6.2215 \quad 2$

It may be thought a matter of furprife in other countries, how a cotticr, with fix in family, could be able to make out $22 \%$. 55 s. $2 \%$, with many other incidental occurrences.

In this county, and throughout all the North of Ireland, fo far as the linen trade is in a profperous way, the difficulty is eafily anfwered; the wheel and the 
loom anfwer all. If a farmer's fervant-girl be able to clear $525 . *$ a year, befides her wages and maintenance from the farmer, what muft a united family of fix perfons do by their induftry in the fame time?

* I take for granted, that fifty-two yards of fine linen will be equal to $52 \mathrm{s.}$, clear of all expenfe. 


\section{CHAP. VII.}

\section{GENERAZ SUBJECTS.}

SECT. 1. Number and Size of Villages and Torwns.

THE barony of Dungannon contains the following towns and villages.

x. Dungannon, one of the moft profperous towns in the North of Ireland in the linen trade, nor is it inferior to any for its rapid progrefs in building. When the new town will be completed, Dungannon altogether will have no equal in the North. In the buildings there is one fault, which generally prevails, and that is, that the houfes are narrow, which, in buildings in general, is certainly bad economy.

2. Cook's-town, tolerably eminent in the linen trade. The mulin manufacture is likely to take place herc.

3. Aughnacloy; linen and yarn.

4. Stewart's-town; ditto.

5. Callidon.

6. Pomeroy. 
6. Pomeroy.

7. Moye; extremely well fituated for trade, having the Blackwater river navigable, fo far as Blackwater town, from Lough Neagh.

The above are the principal towns in the barony; the following are the villages.

I. Orritor.

2. Tullyhog.

3. Dunnaghy.

4. Brackogh.

5. New-mills.

6. Coal-illand; navigation might be improved.

7. Donaghmore; brewery and mill for preparing barley.

8. Caftle-Caulfield.

9. Eglin.

ro. Carnteel.

I I. Benburb; a famous limeftone quarry.

The Barony of Glogher contains,

I. Clogher.

2. Augher.

3. Ballygawley.

4. Five-mile-town.

5. Fintona; good linen market.

The above are fmall towns, but of more confequence than country villages. 


\section{The Barony of Omaghs contains,}

3. Omagh, the affize town.

2. Dromore.

3. 'Trillick.

4. Ballinalsatty.

5. Six-mile-crors.

6. Killetor.

7. Derg-bridge; bleaching might be eftablifhed.

8. Drumquin; bleaching might likewife be eftablifhed here, by removing a mill.

The above are villages, except Omagh.

\section{The Barony of Strabane contains,}

1. Strabane; a good market town for many articles, and efpecially cloth.

2. Newtown-ftewart; a good market for cloth and yarn. Several bleach.greens might be eftablifhed on the river Struel, between this town and Omagh.

3. Dunnamanagh.

4. Ballimagorry; fituation for a bleach-green.

5. Ardftraw-bridge; - ditto.

6. Gortin.

7. Claudy; a fituation for a bleach-green.

Except the two firft, the above are fmall villages.

Strabane is at prefent improving; its canal is the chief caufe. Newtown-ftewart is moft eligibly fituated for improvements of many forts. 
SEcT. 2. State of Tithe, its general Amount on each Article-what Articles are exempt, and what charged by Modus.

UPON this fubject I have but very little to fay, with refpect to any new light, that might be thrown upon it. Much has been faid by others, with regard to reforming tithes, \&cc., which, in my opinion, can anfwer no material end.

With refpect to this county, I find, in general, a very good underftanding between the incumbents and the people. Some let their tithes during their incumbency; fome yearly, at fo much an acre, feldom exceeding two Millings for good arable and meadow. Others lay on fo much an acre againft oats, barley, hay, flax, and potatoes: the three laft articles are, in general, lct at moderate terms, frequently not acreable, only fo much by modus. The moft general way is by yearly compofition; nor could I learn, that the extravagant prices of provifions, in the years 1800 and $180 \mathrm{I}$, made the leaft alteration in the raifing of tithes throughout the county. When let by compofition, large and fmall tithes are of courfe included in the contract, though the latter are feldom of any material confequence to the incumbent. 
The following is a lift of fmall dues, given by 2 neighbouring clergyman as a very old cuftom in' his parih, but never exacted. I fuppofe the fame holds good in moft parihes throughout the diocefe, and alfo not demanded; at leaft I never could learn, that they vere.

Modus.-Turf 6d.; garderi 1s. $1 d$.; Eafter dues $4 d$.; a new-milch cow $9 d$; ftripper cow $4 \frac{x}{2} d$.; theep or lamb $1 d$.; foal $6 d$. Marriage 2s. $6 d$.; chriftening Is. $6 d$.; burial is. Each tradefman is. yearly.

Oats and barley are the principal articles, on whicli an acreable charge is made; the former from 4 s. to $6 s$. , and the latter fometimes as high as $8 \mathrm{s.}$; but this mode is not general.

SECT. 3. Ufe of Bier and Spirits-whether either, or which is encreafing.

THE cxtreme dearth of food, in part of the year 1799 , and the whole of the years 1800 and 1801 , put a total ftop to the diftilling of fpirits, and, in a great meafure, to brewing.

For many years back, fpirits have taken the lead of malt liquor in a confiderable degree. I am not altogether clear, but the quantity of fpirits, diftilled in this county for the laft forty or fifty years, was more than double 
double the quantity of beer brewed. I am certain, when all the private liquor is confidered, the comparifon will not be thought furprifing.

At prefent it is a pleafant reflection to find, that the fcene is about to be altered, and that in a fuperior degree, in favour of malt liquor. The number of breweries lately eftablifhed, and about to be fitted up, is a convincing proof, that malt liquor is taking the lead, or at leaft bids fair for it. Arother circumftance is the rapid demand brewers have, infomuch, that few of them will give any credit.

The following are eftablimed breweries.

- One at Dungannon, on a large fcale.

Two at Donaghmore, near Dungannon.

One at Stewart's-town.

One at Aughnacloy, on a large fcale.

One at Newtown-Rewart.

Two at Strabane.

SEcT. 4. State of Education, Schools, and Charitable Infitutions.

A school, under the patronage of Mr. Stewart, \&c. I am informed, has been eftablifhed at Cook's-town fome time ago.

At Rafh, under the protection of Lady Mountjoy', and Mifs Gardiner, a fchool for twenty-four girls has 
been lately eftablifhed. Sewing, fpinning both linea and woollen, manufacturing ftraw hats, \&c. are the chief occupations of the girls; nor are their moral duties neglected, but, on the other hand, ftrictly attended to.

With refpect to education, attainable from dayfchools by the lower clars, very little real benefit can be derived; as, when children are able to perform any fort of work, fuch as herding of cattle, they are then taken from fchool. From the age of fix or feven, to that of ten or eleven years, is the ufual time for children to be kept at fchool; at this carly period they acquire bat little, and that little is generally forgotten, before they come to the age of underftanding.

Even the children of farmers and others, above the level of common labourers, fare but very little better than thofe of the lower clafs; as their fituation in life obliges them to early habits of induftry, without which rents cannot be paid.

From night-fchools alone, real benefits, to the foregoing claffes, are molt likely to derive. What I hall here offer on this fubject, is founded upon confiderable experience.

An extenfive night-fchool has been eftablifhed, under the fanction of the late Lord Mountjoy, for the purpole of inftructing the labouring boys of the demefne, being principally planters. This has been an early inftitution of his Lordßnip's, fo far back as the 
year $: 783$, and has continued to flourifh and profper to this day.

It generally commences about the firft of October, and continues to the firft of February, and fometimes later. Hours of attendance, from fix in the evening to ten or eleven o'clock at night. A guinea a month is the mafter's falary, for any number of boys not exceeding fixteen, which is the highen number allowed. The boys are always divided into claffes, and three or four guineas are allowed in the feafon, to be diftributed in fmall premiums, fo regulated, that every individual may, at one time or other during the feafon, come in for one or more. This mode not only has for its object the firring up of emulation, but enables them to purchafe paper and candles, as a reward for their diligence.

The hope of obtaining premiums for the time to come, or for the next winter feafon, has an amazing good effect during the fummer months, as they are as induftrious as poffible, between working hours, to keep in mind, or rather encreafe, what they have acquired the preceding winter; and, the better to enable them to do this, they are generally allowed, from ten to two o'clock, to inftruct each other, in fuch parts of the demefne as they may choofe to refort to: but when this indulgence is given, which only takes place in the longef months, they go to their work at five in the morning, and quit at feven, or, perhaps, half after feven in the evening. 
The refult of this falutary inftitution has proved demonfratively its good effects. Within the laft fifteen years, many ufeful perfons have been feat to various parts, as planters, Sc.

But the great object is, the preventing of idienefs, which is always beft accomplined, by filling up the fcraps of time.

Many fimilar inftitutions might be adopted throughout this extenfive and populous county, though, perhaps, not with equal facility; yet they could not fail in being productive of a great deal of good. When we Shall have the happinefs of feeing farming focieties eftablined, they, no doubt, will confider this object. Much might be done by contributions at houfes of worfhip. Grand juries might alfo countenance fuch inftitutions.

I often regretted to find fuch a number of children, both male and female, occupied the greater part of the ycar in herding cattle; but this wretched habit is not peculiar to this county. 'This muft be fubmitted to, till our fyntem of enclofing becomes more perfect.

But fince, in our prefent expofed ftate, thofe little bcrds* are indifpenfibly neccffary, we fhould endeayour to fill up their vacant time as ufefully as polfible.

From

* Herds, or fuch as have the charge of cattle, molt comnoonly turn out indifferent labourers. 
From nine or ten o'clock in the morning, till two or three in the afternoon, in the fummer feafon, the cattle are honfed, for the purpofe of encreafing manure: during all this time, thofe, who have the charge of them, do nothing but idle away time. In every diftrict, a country fchool-mafter is to be found, and a fmall pecuniary matter would anfwer to pay for a few hours each day for the fchooling of thofe children; this might alfo be an object for farming focieties, \&c.

SEcT. 5. Of abfentee and refident Proprietors.

There are very few proprietors in the county, who may be confidered as total non-refidents, or, at leaft, fuch as live altogether out of the kingdom. For inftance, Lord Belmore has feveral properties in the county, yet he is fet down as a non-refident, becaufe he lives in a neighbouring county; the like may be faid of others. Some there are alfo, who have properties in the county, yet refide on rented farms in other parts of it; yet here I do not confider them as actual refidents, they not living on their eftates. There are feveral clergymen, poffeffed of confiderable property, exclufive of church livings, which are here omitted altogether, as the account of the number of parithes is given under the article Ecclefraftical Divifron, and which compofe a large portion of the county, when joined to bihhop's lands. 
The following is a $L_{i j}$ of the principal Proprietors.

Abercorn, Marquis of

Archdall, —, Efq.

Bateman, —, Efq. R.

Bailie, —, Efq. R.

Belmore, Lord

Blackard, —, Efq.

Buchanan, John, Efq. R.

Brabazon, —_, Efq.

Crawford, Henry, Efq.

Colhoun, —, Efq.

Crawford, John, Efq̣.

Callidon, Lord, $\mathbf{R}$.

Caulfield, —, Efq. R.

Charlemont, Lord

Earne, Meffrs. R.

Eccles, Daniel, Efq. R.

Fergufon, Sir Andrew

Forfyth, —, Efq. R.

Gladftanis, George, Efq.

Galbraith, —, Efq. R.

Gorges, Hamilton, Efq. R.

Gage, Mrs.

Gorman, —, Efq. 
Hamilton, James, Efq.

$\longrightarrow$, Sir John

- William, Efq.

-, Hon. A. C. R.

Irwine, Gorges, Efq.

$\longrightarrow$, Henry, Efq.

Johnfton, Charles, Efq.

Knox, Hon. Thomas, R.

Lifford, Lord

Lendrum, James, Efq. R.

Lighton, Sir Thomas

Lowry, Robert, Efq. R.

-, Mrs. R.

Lindfay, Robert, Efq. R.

M•Caufland, John, Efq.

—_ Oliver, Efq.

M.Clintock, —, Efq .

Montray, John, Efq. R.

Montgamery, Hugh, Efq.

Maxwell, Warren, Efq.

Mountjoy, Lord

Moore, Nathaniel, Efq.

_.., John, Efq.

Malone, Mrs. 
Northland, Lord, R.

Perry, George, Efq.

Pettygrew, Robert, Efq. R.

Powerfcourt, Lord

- Richardfon, John, Efq.

$\longrightarrow$, Sir William, R.

Reynell, Richard, Efq.

Strong, - - Efq.

Saville, _.__, Efq.

Stewart, John, Attorney General

Stewart, James, Efq. R.

Tradennick, —, Efq.

Verncr, James, Efq.

White, Francis, Efq.

Waterford, Marquis of

Thofe, marked R. may be confidered fteady refidents, or, at leant, they live the greater part of their time in the county. Befides the above, there are 2 great number of freehold properties in perpetuity, but comparatively fmall; the occupiers of which, with very few exceptions, live on their properties, and are, of courfe, a uffeful part of the community.

SEcT: 
Sect. 6. Of Girculation of Money or Paper.

ThE great perfection, to which the linen manu: facture is brought to throughout the county, but more particularly in the barony of Dungannon, caufes a great circulation of ready fpecie. Except with principal bleachers, and linen merchants, paper currency is not common. In towns, fmall notes are pretty general. With refpect to weavers, and the lower manufacturers of linen, ready carh is the only currency.

Of jobbers in cattle there are many; with thofe, of courfe, nothing is to be met with but hard money, as paper, in our fairs and markets, is never taken as cah.

On the whole, a fmart circulation of hard fpecie prevails, between dealers in cloth and yarn, jobbers, \&zc.

SECT. 7. Of Farming or Agricultural Societies.

Nothing, in the way of farming or agricultural focieties, has yet appeared in the county; it is, however, a pleafing reflection to think, this may not be long the cafe, as the minds of the people are of late much turned that way.

Sect. 
Sect. 8. Of Mills of every kind.

I BELIEve there are only two four-mills in the county, one ncar Dungannon, and the other near Strabane; but the wheat, manufactured in both, is principally the produce of other parts, as at prefent very little of this grain is grown in the county.

The beft mill in the county, for manufacturing oatmeal, is at Cook's-town, which, with very little expence, might anfwer for a flour-mill.

A capital mill for wheat and oats was built a few years ago by Lord Mountjoy at Rah, and there is no doubt, that the neighbourhood will foon afford plenty of wheat to fupply it.

I counted no lefs than 124 mills in the county in 1800. Grift-mills are the common names that mills go by, but this is underftood only of fuch as prepare oatmeal and malt, and fometimes barley for bread, which was univerfally the cafe in 1800 and $180 \mathrm{r}$.

It is not eafy to point out, with any degree of accuracy, the number of effective mills in the county, as fo many of them are perpetually out of order, fome demolining, others repairing, \&c.

In order to afcertain, as nearly as poffible, how many mills, kept regularly to work, might be equal 
to the fupply of the county, I felected fix in different parts of the county. I found the futton, ${ }^{*}$ annexed to the fix mills taken together, amounted to about 28,000 acres, between arable, pafture, \&cc. The county contains 467,700 acres; fo that about one hundred mills, kept fully employed, may be deemed fufficient for the county.

There are mills of other defcriptions, fuch as beetlingmills, one of which mut be at every eminent bleachgreen; tuck-mills, for thickening woollen cloth, and fometimes drugget, which are plentifully eftablifhed throughout the county; flax-mills, for fcutching flax; but thefe are not fo numerous as the quantity of flax, raifed in the county, feems to require, nor are they conftructed, in general, to the advantage they are capable of, fince it is well known, that, by means of fluted cylinders, flax or lint might be broken at the fame time. This would fave a great deal of fevere labour, which, according to the prefent mode of breaking flax, or preparing it for the fcutchers, is unavoidable.

To the above may be added a plating-mill, for making fpades and hovels, at Fintona, and one about to

be

* Sutton is a certain diftrict claimed by mills, in virtue of leafes or agreements between the lord of the manor and the miller; fometimes a whole manor, at other times a half manor, \&c. 
be fet up at Newtown-ftewart; but thefe have been taken notice of in another place.

As in all countries, many of the mills of this county are great nuifances; if better confructed, much fewer would anfwer. There is no end to the difputes between parties, on account of the injury lands fuftain by mill-dams, \&c.

How far fteam-engines might remedy this inconveniency, is a matter I fhall leave others to judge of. I fhall only remark; that the firft coft would be found the only material expence, as fuel is fo plenty, particularly in the baronies of Omagh and Strabane. By adopting fteam.engines, many acres of choice meadowland might be faved to the public.

\section{SEcr. 9. Of Plantations and Planting.}

Considering the extenfive properties in this county, and the eligiblenefs of many parts of it for planting, yet we cannot boaft much of the progrefs of this neceffary improvement.

At Killymoon, a great deal had been formerly planted, and, of late, additions have been made. It would be much in favour of the extenfive plantations of this place, had judicious thinning taken place many years ago. It is not yet too late; much may fill be done for prefeat and future cmolument. 


\section{OF THE COUNTÝ OF TYRONE.}

Át Liffen, the feat of Mr. Staples, near Cook's-torwn, the planting is very profperous : but there is only part of thefe improvements in this county; the remainder lies in the county of Derry.

A confiderable fcope has been planted by Lord Northland, and his fon Mr. Knox, within the laft twenty years, which is at this time in a thriving ftate.

Lord Callidon has planted confiderably in the ornathental ftyle, and, in general, with good tafte. .

Mr. Montgomery planted confiderably near Aughnacloy.

Sir William Richardfon planted, with good tafte, his demefne at Augher, and the plantations are in a flourifhing ftate.

Mr. Montray, at Favoroyal, near Augher, is in porfeffion of large tracts of natural woods, which are managed in an economical manner.

At Clogher, the bifhop's demefne and deer-park afford fome old timber; but this beautiful demefne has been much injured in this, its chief ornament, fome years ago.

Mr. Eccles, near Fintona, has done a good deal in the way of planting, and fo has Mr. Lendrum.

The Rev. Mr. Hill has great merit for his tafte in planting and ornamenting about his glebe-houfe, in the parih of Longfield, near Drumquin.

Mr. Lowry has planted a confiderable number of trees at Pomeroy; but his fituation requires much planting, and in very heavy malfes. 
Mr. Stewart, the Attorney Gencral, has planted with tafte and judgment, in a mountainous fituation at Athenree, near Six-mile-crofs; and, like a real planter, he is laying a good foundation, by eftablihing his own nurferies.

The Hon. A. C. Hamilton has planted confiderably, from time to time, at Beltrum-caftle, near Gortin.

The Marquis of Abercorn has, and is planting largely, at Baron's-court, near Newtown-Itewart. I cannot learn, that he claimed any premiums from the Dublin Society, but I am certain, from the extent of his young plantations, he was frequently entitled to do fo. On the whole, Baron's-court is Atrongly planted, and all the plantations are going on profperouny. It is to be hoped, that the Marquis will perfevere in his original plan, namely, that of planting out the greater part of the north fide of Befly-Bell mountain, which overlooks his demefne. Greater difficulties have been fairly conquered by Lord Mountjoy within thefe last fourteen years.

I might have mentioned feveral other improvements upon fmall fcales. On the whole, the people are bc. ginning to look forward, and fee what is their real intereft.

With very few exceptions, the foregoing have been undertaken within the laft fourteen or fifteen years; and it is a pleafing reflection to find, how much the 
face of the country has been in that fhort time improved, in confequence of thofe plantations.

The following Iketch may ferve to hew the extent of Lord Mountjoy's planting at Rah, near Omagh, fince the year I 779. But firft I muft remark, that no regular account has been kept of the number of trees planted, or the quantity of land taken into plantation, prior to the year I $79 \mathrm{I}$, as in that year the claims for premiums on the Dublin Society commenced. 
Of the Effects of the Encouragement beretofore given to Planting by the Society, particularized in the Liff annexed.

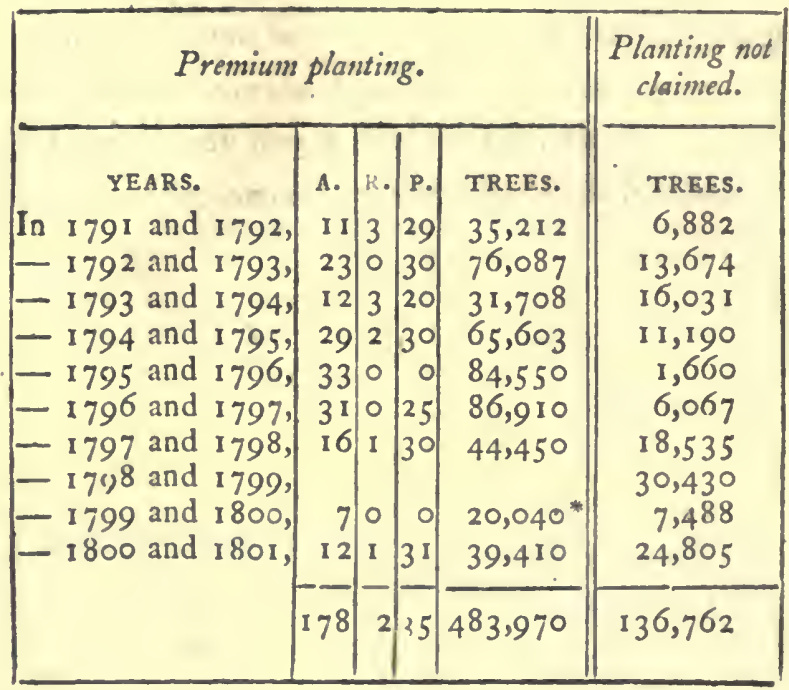

A. R. $P$.

I78 235 Premium planting, 483,970 trees.

$68 \circ \circ$ Not claimed, - - 136,762

$100 \circ 0$ Prior to I791, - - 200,000

I4I $\circ \circ$ Old woods.

$\begin{array}{lll}487 & 2 & 35\end{array}$$$
\text { - } 820,732 \text {. }
$$

Befides

- No premium granted, being under : 
Befides the above, there were given to the tenants of the eftate, fince the year 1795 , upwards of 100,000 tranfplanted trees; and, from the commencement of the improvements at Rah to the foregoing year, I dare fay, there were double the number here mentioned given out, of which, however, no regular account has been kept. Without exaggeration, 300,000 trees were made prefents of to gentlemen, fince the year 1784 .

The article, alluding to the account of premiums, is perfectly accurate, both as to the quantity of land, and the number of trees; but the plantations, formed between I79I and I801, both years included, for which, from local caufes, premiums could not be claimed, are only fuppofed to be, according to the ufual mode of planting here, fair tranfplanted trees, not lefs than four years old, and at leaft once tranfplanted, at about the diftance of fix feet apart, which is found nearly equal to 2000 plants to the acre; but premium planting is never confined to this number.

The plantations, formed prior to the year I 791 , are fuppofed to be equal to one hundred acres; if furveyed, I dare fay they would amount to more. Thefe arc fuppofed 2000 plants to the acre at prefent, but exceeded that number confiderably fome years ago, as a large porticn of this part had been originally under nurfery, which had been from time to time thinned 
out; and, of late, cutting out, inftead of thinning by tranfplanting, took place.

For the laft twenty years, there never were lefs than fix acres of fair well eftablined nurfery at $\mathrm{Rahh}$, for the fupply of the improvements, \&c. By doing the plants full juftice in point of room, an acre may afford annually 20,000 plants, as 40,000 are not too many for an acre, when completely ftocked; fo that, by letting the plants remain two feafons in the nurfery, there may be always an annual fupply of 20,000 ; but this mult be underftood of gentlemens' nurferies, whó may be fuppofed not farce in ground; but it is quite otherwife with nurfery-men, who commonly overftock their nurferies, and, of courfe, the plants are too much drawn up for want of room.

Six acres of nurfery, according to the above fatement, would produce, in twenty years, 2,400,000 plants; and I have lnewn, that

820,732 trees were planted in the demefne; 100,000 fuppofed to have been given to tenants.

920,732

This thews a great difference, between the fuppofed produce of fix acres of nurfery in twenty years, and the number here ftated, which can only be accounted for by the great quantitics of trees put out as nurferies 
feries (now maffive plantations), prior to 1791 , and what were given' as prefents to the gentlemen of this county and others,

Of any improvements, which may occur for future encouragement, and particulurly for the prefervation of Trees when planted.

Without clofe attention to the following requifites, it is in vain to plant.

Complete fencing, and guarding againft cattle. Preparing the foil according to circumftances, particularly in rendering it fufficiently dry, when it is naturally too wet. Encreafing fhelter by every means, where neceffary; and planting judiciounly the different fpecies of plants, agreeably to the foils and afpects they are beft calculated for.

The different modes, made ufe of for the encouragement and prefervation of plantations, thall be fully ftated, when I come to treat of Lord Mountjoy's improvements at large, to which I hall refer as a model, that has been found, from feveral years experience, ta have completely anfwered the end,

It is in the power of the Society to adopt a mode, by which planting cannot fail of being confiderably improved.

Hitherto 
Hitherto, no reftrictions have been laid on the fize or age of plants, under the head of premium planting, and, of courfe, vaft quantities of feedlings have been planted, fince the commencement of this falutary inftitution.

Seedlings in general are not calculated for our foils, upon the great fcale of planting. It is in vain to purfue the fame modes here, as are practifed in Scotland, and other parts of Great Britain; the luxuriance of our foils, in general, points, out the abfurdity of the fyftem.

The Society requires, that a certain number of plants muft be firft planted to-each plantation acre, and that a giren quantity mußt be kept up for a certain number of years. When feedlings compofe part of fuch plantations, they muft be narrowly watched from time to time, in order to keep up the quantity fpecified by the Society.

I know, from much experience, that this mode in the end becomes very expenfive, and that at the lofs of many thoufands of trees, which might otherwife be fared; and, after all, the defired end is fcarcely ever completely anfwered, at leaft, not fo effectually, as if the planting had been formed, the firft day, of regular well-conditioned tranfplanted trees, that would at once defy the luxuriance of our fpontaneous growth, and give no further trouble, after being fairly planted, till the operation of thinning Should take place. 
The improvement I beg leave to fuggeft is, that the valuable trees, fuch as oak, larch, Spanifh chefnut, beech, fycamore, elm, afh, pine, \&x. Thould at leaft be once tranfplanted, and that for two feafons before they are put out for good; fo that, in moft cafes, the plants Thould be four years old at that time, which, for the generality of deciduous trees, is certainly the beft age.

In this cafe, the number of valuable trees might be limited to one thoufand to each acre, which might be replaced, in cafes of accidents, agreeably to the term fpecified by the Society.

I would lay no reftraint upon any quantity of infe. rior timber the Society might think proper to allow, over and above the number above ftated, fuch as birch, alder, mountain-âh, \&c.; thefe, with fome of the poplar and fallow kinds, are free growers, and capable of taking care of themfelves, though put out as feedlings, or cuttings.

SEcT. 10. Of Nurferies quithin the County and Extent of Sales,

ThERE is not a nurfery for fale within the county, though few counties in the kingdom are better calculated for that purpofe. I am fully convinced, that planting would go on rapidly, were there only a few eftablinged 
eftablifhed nurferies, where planters might refort to, without being at the expence of fending to diftant parts. It is not the price that ever deters men, who only plant upon a finall fcale, but the diftance of carriage, and the hazard of fuffering by bad packing, and of the plants being too long out of ground. Thefe are certainly fome of the principal caufes of planting not being more general, and not any pecuniary views. . In the courfe of my agricultural excurfions in I 800 ; and 1801 , I have had many unpleafant reflections, in travelling over wafte tracts, which are fcarcely calculated, or ever can be, for any purpofe, except for planting, and where little or no expence in enclofing would be found necefrary, particularly in rocky fituations, where large ftones are in plenty, and might be eafily collected to form rough dry walls.

The firft great point to attend to, Mould be to give every kind of encouragement to nurfery-men, confining them only to common articles, fuch as thornquicks, afh, oak, beech, larch, fir, fycamore, alder, \&c. Grand juries and farming focieties might do fomething by way of encouragement, as well as the Dublin Socicty.

Were nurferies eftablifhed fufficiently numerous, gentlemen would be induced to plant one hundred trees for the one they do at prefent; and, when planting became general, there would be no temptation for ftealing, fince it is a well-known fact, that, when any 
article becomes plenty, the temptation for pilfering diminifhes in proportion to the encreafe, of the article. I dare fay, when potatoes were firft introduced, it was found difficult to fave them from the common people. I know, from experience, that, when the turnip fyftem was firft eftablifhed at Collon, by the Right Hon. John Folter, for the firft feafon vaft quantities of them were taken away by the common people; but it was foon found, that, by giving up a finall part of a field for the purpofe of fupplying every poor perfon, who might want a few turnips, and giving a little turnip-feed to fuch as might be difpofed to fow it, it foon put an end to any thing like pilfering.

So, with refpect to timber-trees, if nurferies were eftablifhed, fo, as to make thefe articles general, and that gentlemen would turn their thoughts upon dividing with their tenants, or otherwife encourage them to raife or purchafe plants, we would, in a very little time, find all people difpofed to purfue one common caufe. This, with long leafes, and other encouragements, would foon make a great change in favour of planting. - I have often turned my thoughts, with refpect to the moft eligible fituations for nurferies in the county. Strabane, Omagh, Aughnacloy, Clogher, and Dun. gannon, appear to me the beft; not only on account of finding at thofe places favourable foils and fituations, but alfo of dividing the county tolerably regular, and, in general, convenient to the neighbouring coun- 
ties, which could not fail of finding material advantage from fuch fituations.

Befides the encouragement already mentioned, given by the Dublin Society, \&x., much might be done by the gentlemen of landed property, without being at any material expence to themfelves. A kind of guardianhip over the refpective nurferies is as much as might be expected from them or their agents; to fee that the fales might go on regularly, the prices fettled once a year, and proper returns of ftock made out, with other ufeful regulations.

'The nurfery, we thall fuppofe at or near Strabane, might be patronized by the Marquis of Abercorn, the Birhop of Derry, the Hon. A. C. Hamilton, \& c.

That at Omagh by Lord Mountjoy, Lord Belmore, Mr. Stewart the Attorney General, \&c.

That at Aughnacloy, Clogher, or probably Fintona, by Lord Belmore (as he has extenfive properties in the county), Sir William Richardfon, Mr. Montray, Mr. Montgomery, Mr. Eccles, \&zc.

That at, or near Dungannon, by Lord Northland, Mr. Knox, Lord Powerfcourt, Lord Callidon, Lord Charlemont, Mr. Stewart of Killymoon, \&:c. 
Sест. II. Prices of Timber, and State of it in the County.

THE prices of timber are very high, and it is difficult to procure upou any terms. The Hon. A. C. Hamilton's woods, in Munterloney, for many years back afforded the chief fupply to the county for cabin-buildlng, nidecars, ploughs, \&c., but thofe woods are now almoft cut down. The woods were chiefly of oak, and will, of courfe, be a confiderable time before they come round: again, as the time limited to keep cattle out, after being cut, is by far too little, not more, I underftand, than eight years. Indeed cattle fhould never be fuffered to get into woods at any period.

At prefent a couple, or principal, for a cabin of fixteen feet wide, cofts from 5 s. to $85 . ;$ a dozen of ribs for a cabin, from 6 s. to ros.; a lide-car 5s., and fo on. The timber is never fold by the foot from thofe woods, as the dimenfions are too fmall for that purpofe.

Afh is remarkably fcarce; it is chiefly ufed for wheel-cars and ploughs: the ftuff for the former ufually cofts two guineas, and the latter from I 2 s. to 16s.: many of the latter are made of oak and birch, but an is much better for that purpofe. Alh is frequently fold by the cubical foot, at fo high a price as $3 s \cdot 3 d$. 
Foreign fir at this time (1801) fells at Strabane fo high as $6 \%$. per ton.

The chief reliance the county has, is upon bog-fir, which many of the bogs produce in great plenty, but it is in general attended with great difficulty and expence in being able to manage it, for want of roads, and proper conveniencies to raife it. This timber is fometimes fold at half a crown the cubical foot, for the purpores of loom-timber and mill-lhafts, but bog-timber in general is fold by bulk, efpecially bog-oak. Even-grained bog-fir is looked upon to be full as good for roofing and lofting ftables, \&c. as foreign fir or pine; it makes excellent laths, and, when beaten out into fmall filaments, is found to anfwer for ropes, which are principally ufed for cording of beds, and, in damp places, will laft confiderably longer than hempen ropes. Twenty yards is the ufual length for a bed-cord, which is commonly bought for rod. The roots and fragments of the bog-fir are ufed for this purpofe, and it is a kind of trade with many poor people in the vicinities of bogs.

It has been ftated, under the article Habitation, fuld, food, \&cc., how far the thinning of Lord Mountjoy's improvements ferves the country, fo ifar as alludes to cabin-building. Here I Mall only add a few articles, wed for other purpoles.

A nide- 


$$
\text { f. s. } d \text {. }
$$

A lide-car of fpruce-fir, - $\quad-033$

Car-feet of birch or alder, per pair, - $\quad \circ \quad 0 \quad 6 \frac{1}{2}$ A ladder, from twelve to eighteen feet, of

fpruce-fir, from 6s.6d. to - - $010 \circ$

A plough of birch, - : - - 012,0

A two-horfe harrow of birch, - -0.80

Shovel, and fork-handles, of ah, each, $\circ \circ 6 \frac{x}{2}$

Swingle-trees of ah, each, - - - $0.06 \frac{2}{3}$

Rakes, finifhed, of ah, each, - - 0 I I

Turf-kihes of various forts, each, - $\quad-66$

Manure-kinhes, each, from $2 s .2 d$. to $-\circ 4.4$

Potatoe-balkets, each, from $6 d$. to $\quad \circ \quad$ I $\circ$

SEcT. 12. 2uantity of Bog and Wafte Ground,

IT is not eafy to afcertain the quantity: of bog and wafte ground throughout the county; and, even if it could be actually made out, it would only anfwer for one feafon's information, as every year adds confiderably to the quantity of land brought into culture, mea. dow, and pafture.

Perhaps, within the laft twenty years, this county. has made as rapid a progrefs, with refpect to the bringing in of wafte land, as any other in the kingdom, and particularly mountain; yet a vaft deal remains to be dope, 
done, and much of what has been done is fill capable of furthèr impprovēment.

\section{Poftrbility and means of improving it.}

To enter into a minute detail of the different practical modes, neceffary to purfue for the improvement of the great variety of foils of this county, would require a large volume, which, however, at a future day, I hope to fet forth in another work, now in tolerable forwardnefs. At prefent I Mall only ftate a few obfervations, relative to the great outlines of reclaiming unprofitable land.

I have already treated largely on the fubject of roads; but the nature of the object under confideration requires me to fay a little more here. It has been obferved of what infinite advantage roads are, in helpIng to get at bog-timber, limeltone, \&c." Now, in cafe of bog-timber and limeftone being altogether out of the queftion, and that a large fcope of bog or mountain was in contemplation of being reclaimed, the fir $\mathbb{t}$ object the cultivator thould have in view, after drain. ing, are roads, to draw forward materials to reclaim fuch parts; therefore draining and making of roads Should go hand in hand, fince their dependance on each other is fo nearly connected.

- It is the public who pay for roads, and there is no doubt that every encouragement Mhould be given to 
them; to make the molt they can of every circumftance, that may naturally occur in their refpective difticts, for the improvement of their lands.

Since timber is at prefent fo extravagantly high, and the profpect of a fupply of it, for domentic purpofes, fo very remote, every advantage fhould be taken, to accommodate the public with the kind of wood, that naturally offers in almoft every bog in the county, enough, I dare fay, to fupply the country for ages; but the extreme difficulty of being able to get at it, when raifed, renders it, in many cafes, dearer than foreign timber, when all the trouble attending it is confidered.

Among the various means of improvement, none appears more effectual than watering or irrigating land, when at all practicable. It is, indeed, a very pleafing reflection to find, what rapid ftrides this ufeful improvement is making of late. But, as might be expected, the people in general are ignorant, both of the proper application, and execution of the work; but, no doubt, they will foon fall into meafures fo nearly connected with their real interefts, and where fo little fpeculation is neceffary to remove every doubt of hazard or rifque. It is the genius of the people of thefe parts, to embrace immediately any improvement, in which a fpeedy return of gain is the prevailing object; among which the fubject under confideration is one of the utmoft importance, fince the expence is nothing, 
when compared to the great benefits to be derived,? and efpecially, when the work is executed in a good manner.

Farming focieties, no doubt, will always encourage this fpecies of improvement.

Mr. Stewart, of Stranorlan; in the county of Donegal, has fet a good example on-foot, with refpect to draining and irrigation. He brought over from Staffordhire a 'perfon, who has given a ftrong fpecimen' of the good effects of irrigation, and, of courfe, has fct a good example to others: 'This perfor is now (I802) actually employed, at fo much a year, by the Raphoe farmers' focicty. Indeed I may date the commencement of irrigation, done in a workman-like manner, from Stranorlan, in the year 1800 , which was the commencement of Mr. Stewart's operations.

I am very far from being againft importing perfóns from England and Scotland, for the purpofe of water-: ing, or any other improvement; but, upon the oth hand, in fothe particular inftances, I approve of it." In. general, however, I apprehend; that this country would reap more folid advantage, and that in a morter time, by fending perfons to thofe parts, and particularly to the Lothians of the latter.

The fubject in queftion admits of fo many modes of performing it, that it would take up a volume to do it' any degree of juntice, and, after all, much would remain to be done. There is fearcely a fpot, which does 
not require fome mode peculiar to itfelf. There is, however, one circumftance, which muft always be complied with where neceffary; otherwife watering, inftead of improving land, will injure it, and render it worfe than before the operation took place. This is, the effectually getting clear of fprings, and ftagnated water, before irrigation be attempted.

The great point to confider is, to cheapen the work as much as poffible, where draining is neceffary prior to watering, as many of thofe drains, neceffary to drain the land, may be alfo found ufeful to act as conductors or leaders, to anfwer irrigation; that is, when the act of irrigation is not going on, many of the drains may perpetually act in draining.

There has been a good deal faid of late, on the fubject of draining, by Elkington and others, to which I sefer. In many cafes, great accuracy in levelling is requifite: the fpirit level is not in the power of every farmer, and even if it was, few underftand the application of it. The common mafon's level is tedious; for expedition, the ifofceles triangle is the beft, and is as accurate as any: with this a man can level almoft as faft as he can walk, attended by a boy to carry pins, to ftick down where the level may point out.

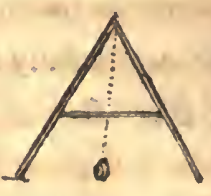

o

There 
There is a great deal in habit in any undertaking; fo with lovelling; a good eye never fails to facilitate this kind of bufinefs.

In i $80 \mathrm{i}$, I found a great number of Lord Mountjoy's tenants bufily cmployed in watering their theadow's and pafture-grounds. As it was the firft year, of courfe it was managed in a novenly and imperfect manner." I fingled out a perfon, who was in the habit of watering for fome little time before in the demefne. This man has an exceeding good eye, and has alfo 2 great liking to irrigation, which is every thing. I fent him, with his fimple triangular level, through the eftate; and, in the cotirfe of a few weeks, he made 2 wonderful reformation in the ideas of the people, fo that now the greater part of them are practitioners, and irrigation is become quite a fcience among them.

- I only mention this circumftance as a hint to improvers; as every neighbourhood in the kingdom muft have fome perfons, whofe abilities are fuperior to thofe of others, and therefore it fhould be the object of the proprietors to felect them.

'The advancing of money to poor tenants, at the time of taking out a leafe, would, no doubt, in many inftances, produce a good effect, in forwarding the means of improvements, or rather placing the money on fuch a footing, as to be occafionally laid out on improveinents, according to contrast.

Tenants 
Tenants in general are fo wretchedly poor, that a great length of time elapfes before any permanent advantage can derive to them from the improvement of their farms. Indeed it is too frequently the cafe, that; during the whole courfe of the leafe, for want of means or ability, the farm does not yield probably one-fourth of what it might have done under good management, and laying out fome money early, for ditching, draining, liming; \&c.

Inftead of the landlord being a lofer by this mode; he would find, at the expiration of the leafe, a great benefit, and encreafe of property.

If, for example, a farm confifts of twenty acres, at 10l. a year upon a thirty-one years leafe, let the land: lord, for the firft fifteen years, advance $3 l$. a year, to be laid out in draining, liming, \&c. The next fixteen years, the rent may be raifed to ${ }_{3}$ l. a year. By this mode, the landlord will be nothing out of pocket; and it is very plain, that no intereft, accruing from 45 l.; could be equal to the encreafed value of the land, at the expiration of the leafe.

There might be other modes adopted, to enable the tenant to get on, according to circumfances; I only fuggeft this as a hint.

- It is evident, that long leafes muft be a powerful means of improving lands. Upon fhort leafes; fuch as twenty-one years, men have no fpirit to get forward, and efpecially where confidence does not exilt between 
mafter and tenant, which, indeed, is too often the cafe.

Farming focieties may produce a good effect, by giving premiums, and alfo by employing perfons, Rilled in the improvement of bog and mountain; to infruct the people.

Much might be done with refpect to burning of lime upon a large fale. Public lime-kilns mould be introduced, and fome bounty or premium offered; indeed, without them; lime would find its own level, by charging a reafonable price. This is fully demonftrated by Mr. Stewart aforefaid, who built a kiln feveral years. ago, and continues to fell the lime to his tenants at a reafonable rate, and to tenants of other eftates at a more advanced price than what he charges his own. The good effects, produced by this inftitution, foon became evident throughout his eftate, fince, for every barrel of lime, that had been formerly laid on the land, twenty barrels have been ufed fince the eftablifhment: of the kiln.

From my own knowledge of this county, I am inclined to believe, that, by eftablifhing lime-kilns, and felling at a reafonable rate, it would be found one of the beft improvements that could be introduced.

A barrel of lime, containing thirty-fix gallons, " generally cofts from $18 d$. to 2 . The carriage of limeftone,

* The barrel Should be forty-two gallons. 
Stone, for perhaps three or four miles, renders this article extremely high, as the ftone is confiderably heavier before than after it is burned. The true plan, therefore, is, to have the lime-kiln built as convenient to the quarry and bog as poffible, particularly to the former.

At a public lime-kiln, where bufinefs is weil attended to, there will feldom happen any difappointment; whereas there is no end to the delay and trouble attending lime burned in the ufual way, in little forry pot-kilns, ${ }^{*}$ which are perpetually out of order.

Fully convinced of the utility of a public kiln, I have engaged in this bufinefs upon a large fcale, and am convinced, that I fhall be able to fell lime at I 4 d. a barrel the year round.

Obfacles to improvement, and the beft means of removing them.

The means of improvement, being underftood and complied with, muft, in fome meafure, remove the obftacles.

* A pot-kiln is nothing more than a hole dug out of the fide of a dry bank, built up with ftones, without any cement, one fide of which muft be broke, up for the purpofe of getting out the lime, when burned. Thefe kilns are of various fizes, but feldom exceed thirty barrels of roche-lime: 
- The following feem to be among the greateft obfacles to improvement.

Rack-rent appears to be the molt diftreffing to the community at large, but particularly to the cultivator of the foil, and never fails to affect the head landlord in fome degree. The more intermediate tenants there are, between the lord of the foil; and the perfon who cultivates it, the worfe for both, becaufe it is very evident, that every perfon, who may have a clain or an intereft in the land, will, of courfe, have fome profit. This clearly points out, that the landlord is not paid the real value for his land, and that the under or loweft tenant pays a great deal too much.

Happy would it be for the profperity of the kingdom, if no perfon was concerned in land, except the lord of the foil, and thofe, who actually cultivate it.

Agents, not acquainted with country bufinefs, may be confidered a great bar to improvement. The improvement of land depends very much upon the actiyity and knowledge of agents.

I believe it is a general cuftom throughout the kingdom, to exact duties of men and horfes from the tenantry of eftates, to bring home the landlord's fuel, corn, \&xc; I know it is generally the cafe in this county. In another place, under the article, General fate of Leafes, I have pointed out fome objections to this mode; here I have only to remark, that I confider it a great impediment to induftry, becaufe fuch as are 
bound to fulfil fuch petty engagements, muft always attend at feafons when their own works are molt. prefling.

The fituations of many mills are alfo great obftacles to improvement.

There is another circumftance, much complained of by farmers in general. ' They have a notion, that bog and mountain, newly reclaimed, muft become fubject to tithe, fo foon as they are brought into a fate of cultivation. I underftand, that fome fecurity is fettled by law for new improvements; of this, however, the people are in general ignorant.

SECT. 13. Habits of induftry, or want of induftry? among the people.

IT is rare to find more induftrious people, than thofe of this county generally are. The want of induftry proceeds more from not having the means of being induftrious, than from the inclination of the people towards idlenefs. In tracts, capable of producing corn; potatoes, and flax, we find few fpecimens of floth or inactivity; both men and women are ufefully employed? At night, in the winter time, it is very common for a labourer to make $6 d$. or $8 d$. by weaving, after his day's labour. Girls, of nine or ten years of age, generally make from Is. to Is. 6 d. a week by fpinning. 
It is only in the mountainous parts that we find ang thing, that appears not indufrious. In thofe parts, the management of potatoes, oats, and turf, is chiefly the outer work, which occupies the men only part of the year; the remainder is generally employed in weaving.

Whenever tafk, or piece-work, occurs, it never fails to excite induftry.

The hardhip the poor people, who occupy mountainous parts, labour chiefly under is the want of flax, as many mountains are not fit to produce that article; therefore they muft purchafe, frequently at a dear rate. Perhaps there is no way, by which the poor could be more materially affifted, than by laying up ftores of flax when cheap, and felling it to them at the firft colt; this might be a confideration worthy of the attention of farming focieties and others.

The various exertions, ufed by many, in collecting manures, are furprifing. I have frequently found half an acre of potatoes in the poffelfion of poor families, who bad not a four-footed bealt except a cat or dog; and all made from mud or mire, alhes, rufhes, fprit, \&c. Broom and furze, in frong clay foils, anfwer extremely well for manure for potatoes, and of thefe. the poor take advantage where they are to be found: $I$ have known good crops of potatoes produced from common heath or heder. 


\section{SEcT. 14. The ufe of the Englifh Language-whether general, or bow far increafing.}

ExcEPT through the wilds of Munterloney (chiefly in the barony of Strabane) the Englim language is moft prevalent; indeed throughout the county it is gaining ground every day. The Roman Catholics are the only fect, who are fond of fpeaking the Irim language, and with them too it is wearing off very much.

The people of this county in themfelves differ as much, perhaps, as thofe of feparate kingdoms. The people of the baronies of Dungannon and Clogher are much more polithed, than thofe of Strabane and Omagh generally are. The inhabitants of Strabane and its vicinity feem quite a different race of people from thofe of Munterloney, who are in the fame barony. In like manner thofe, in and about Omagh, differ from the parihes of Tarmonmaguirk and Tarmonomungan, in the fame barony. This obfervation holds good with refpect to all the towns, and country parts. 
Secr. 15. Account of Towers, Caftles, Monaferies, Ancient buildings, or places remarkable for any biffo-. rical event.

I do not recollect having met a round tower in the county, or any remains of one; and although round towers are peculiar to many parts of the kingdom, yet very few of them are to be met with in the North.

Old caftes are numerous, but in general they appear to have never been of much confequence, or of any confiderable ftrength; many of them, however, are partly compofed of a very ftrong cement, and almoft impoffible to reduce, even with gun-powder.

The following are the moft confiderable in the county.

One in the town of Newtown-ftewart, but not very ancient. Another near the town, circularly built, and of great antiquity. This, we are informed, had been the refidence of the kings of Ulfter. Part of this old caftle projects eight feet beyond its bafe, and has the appearance of being fofpended in the air, fo great is the Atrength of the cement, which keeps the ftones together.

At Baron's-court, near Newtown-ftewart, is an old caftle, fimilar to that in the town, and it appears to be of 
about the fame antiquity. We are informed, that both were burned by the Irim in I64I, and even at that time inhabited. A fourth caftle is faid to have been near the town, but at prefent we can make out no traces of it.

Kerlih caltle, near Drumquin, appears to be very ancient, and is of confiderable extent.

Two old caftles near Dunnamanagh, in the barony of Strabane.

Benburb, on the borders of the county, in the barony of Dungannon, appears to be the largeft in the county. It is built on a limeftone rock, upwards of I20 feet nearly perpendicular, over the Black-water, which at the caftle forms nearly a right angle, fo that two fides of it were completely fortified by nature. Though the materials for building are here remarkably good, both lime, fand, and ftone, yet the caftle was but weakly built, the cement was bad, and the Itones commonly of the pebble kind.

At fome diftance from the caltle, in the village of Benburb, is a fmall ancient building, which appears to have been a watch-houfe belonging to the cafte; this is frongly built. Another fmall building, near the latter, feems to have been intended to fupport a fundial.

At Augher, in Sir William Richardfon's demefne, is a benutiful old caftle upon a frall fcale, which is kept in tolerable prefervation. 
The caftle of moft confequence in the county, is that of Mountjoy, or Mountjoy-caftle, on the borders of Lough Neagh, which is indeed a fine venerable pile of building.

From the great number of town-lands throughout the county, of which the word cafle makes part of the name, fuch as Caftle-town, Caftle-rody, Green-caftle, \&ce. we have reafun to conjecture, that numbers of caftles formerly exifted, of which, at prefent, we can trace nothing but the names. This obfervation is not peculiar to the county of Tyrone; it is general throughout the kingdom.

Except old cafles, other ancient buildings are very rare.

As to monafterics, though a confiderable portion of land is tithe-free, yet I do not recollect having feen the remains of any old monaftery.

Danif forts and Druids' altars are very numerous; the former are held in great reverence by the common people, in any of which we feldom find the traces of the plough or fpade. The planting of fuch confpicuous fpots would add much to the beauty of the country, and the fencing of them would be attended with very little expence, as they are fo circumftanced, that the fence is already in a great meafure completed, or at leaft might be made fo with very little trouble. There are few places where trees would profper better, the foil having been originally colleeted and brought there 
from other parts; and on this account, and from its never being broken up, we frequently find it both deep and rich.

There are other monuments to be met with, held in great veneration by the lower clafs, and particularly thofe of the Roman Catholics, fuch as ftone croffes, many of which are filled with hieroglyphic figures, and holy wells, as they are called, where people make ftations, or perform a kind of pilgrimage. The common people not only act this kind of mummery, as they fuppofe, for the falvation of their fouls, but give the waters to their cattle, at certain feafons, as an antidote againf diforders, which probably do not exift.

SEcT. 16. Churches-Refsdent Clergy-Glebes, and Glebe-boufes.

WITH very few exceptions, the clergy are all refidents. There may be fome inftances of pluralifts, but this is not common in this county at prefent. As to glebes and glebe-houfes, the queftions are anfyered in the firft chapter, under the Divifons of the county.

SEcr. 
SEcr. 17. Whether the County bas been actually furveged-when and whether tbe Survey is publifbed?

Is the jears 1774,1775 , and 1776 , a furvey of the county was made out by Melrrs. William and Conyngham MiCrea. A very accurate and well executed map was made out for the gentlemen of the county about the fame time, which is always to be feen in the Grand jury room of the county, at the time of the affizes, for the purpofe of infpection.

Under the article, Roads and Bridges, I have taken notice of this fubject, with refpect to the manner of improving this map, to which I refer.

SECT. 18. Weights and Meafures, liquid or dry-in vobat infances are Weights afigned for Meafures-or vice vorfa.

EXcept tar, and treacle or molaffes, liquids are fold by meafure; thefe articles are generally fold by weight. Honey is fometimes fold by weight. Selling by weight is preferred, in order to avoid wafte, becaufe thofe glutinous fubftances adhere, in a great degree, to the velfels, in which they are meafured; fo that, by firft weighing 
weighing the veffels, in which they are intended to be put, wafte is effectually avoided.

Oats and potatoes are occafionally meafured, between parties in the country, but very feldom in the public market.

SEcT. 19. The Weight or Meafure, by which Grain, Flour, Potatoes, Butter, छc. are fold.

GraIN is commonly fold by weight in the public market, but oats are ufually fold by meafure between farmers, and efpecially feed-corn. Six ftone, of 14lb. avoirdupois, is reckoned equal to a meafure of oats, and three meafures, or eighteen ftone, to a barrel. When bought or fold by weight, the price is commonly fettled by the ftone. Seven ftone is confidered. equal to a meafure of barley, and three meafures, or twenty-one ftone, are equal to a barrel; this is alfo. ufually contracted for by the ftone. Twelve ftone is a barrel of malt, which is always fold by weight. Barley is feldom fold at the public market; private diftillers buy vaft quantities of it by private contrakt, and by fample.

Flour is fold by the hundred weight, of eight ftone, or II 2 lb.; it is alfo retailed by the ftone, and by the pound.

Oatmeal 
Oatmeal is almoft univerfally fold by the peck of rolb. by retail; twelve pecks being equal to the long hundred, or 120lb., which is the ufual ftandard for oatmeal. In fome parts oatmeal is fold by the fcore, which is equal to two pecks, twenty of which are confidered a barrel of meal, being equal to $3 \mathrm{cwt}$. 2 qrs. $8 \mathrm{lb}$. of the thort hundred, or $112 \mathrm{lb}$.

Potatoes ate generally fold at market by the ftone, but the farmers fell large quantities in the country by the meafure, which is reckoned equal to eight ftone; but, when heaped, as is the ufual cuftom, the meafure generally exceeds nine ftone. A meafure of potatoes weighs more in winter, than in fpring or fummer; the fame remark will hold good for oats. Oatmeal certainly encreafes in weight by age, but fince that article is fold by weight, there is no danger of the poor fuffering. In general, throughout the county, forty ftone of potatoes is equal to a barrel.

Frem butter is ufually fold by the pound of eighteen ounces; but falted butter is fold by the ftandard pound of fixteen ounces.

Flax-feed is always fold by the gallon when retailed, and by the hoghead when fold by wholefale. The hoghead contains from fixty to feventy gallons.

Hides and tallow are fometimes fold by the fhort hundred, or I $2 \mathrm{lb}$., and alfo by the long hundred, or 120lb.; either of which cannot affeet the buyer or feller, as the price by the pound is always underftood. 
Candles are fold by the pound, and foap by the ftone and the pound.

Notwithftanding the murmuring, refpecting weights and meafures in other counties, I think in this county there is no juft caufe for complaint, fince the pound of fixteen ounces, and the ftone of fourteen pounds, are fo well underftood, by which the foregoing and many other articles are governed. I fcarcely know of any exception, unlefs in wool and frefh butter; the former is rated at $16 \mathrm{lb}$. to the ftone, and, whether fold by wholefale or retail, the price is generally gan verned by the pound. 



\section{APPENDIX.}

An Account of Lord Mountjoy's Improvements at Ra/h, and the manner of carrying them into execution, from the year 1778 , to the prefent time.

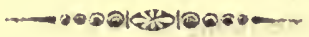

SECT. I. Seminary and Nurfery.

EARLY in the year 1778 , the firft ideas for the improvements took place; but, for the two firft years, little more was done, than the eftablifhing of feminaries and nurferies, which, confidering the great extent of the defign, required to be upon a large fcale; It was not the fupply of the demefne alone, to raife trees for, that was in contemplation, but that of many large mafles of planting throughout his Lordhip's eftates in this county, amounting, in the whole, to about 36,000 plantation acres. Thofe objects, with that of being able to fupply a numerous tenantry with fuch foreft- 
trees as were found fuitable, required to keep up extenfive and regular courfes of feminary and nurfery.

It was foon found neceffary to-eftablin nurferies in various parts of the demefrie, in order to fave the expence of carriage, and alfo to give the young plants a habit, from their infancy, to bear the different expofures they were intended for, with a certainty of fuccefs. This fcheme was found to anfwer completely; indeed, upon fo large a fcale, it would be wrong to confine the nurfery to one or two particular fpots.

The Right Hon. John Folter, no doubt, was the firft who eftablifhed nurferies and feminaries, to any great extent, in his own demefne at Collon, in the county of Louth; and it is to him alone we are indebted for this, and many other falutary inftitutions.

The late Lord Mountjoy was one of Mr. Folter's earlient pupils, with refpect to planting; and time and perfeverance have thewn, that his Lordhip made a rapi:- progrefs, not in planting alone, but in various other improvements, fuch as draining, enclofing, laying down grounds of various defcriptions, embanking, \& c. Thefe, with feveral other improvements (many of which fall within the plan fuggefted by the Society), I Mall in this place endeavour to make clear.

At the commencement of the improvements, vaft quantities of feedlings were ordered from Scotland and other parts. 'This was done with a view of faving, or rather gaining two feafons, as the plants, fo purchafed, 
were fuppofed to come round for planting out for good, two years fooner than thofe raifed from feeds fown at the fame time that the feedlings were ordered. In fome inftances this precaution anfwered; but, in general, the feedlings, raifed upon the fpot, proved vaftly fuperior to any of thofe imported; and at this time (1802) there is no comparifon at all between the feedlings, got from Scotch and Englifh nurferies (generally two years old), and plants raifed here from the feed, notwithftanding the difference of two years in point of age.

In fix years we find, that feedlings in general, raifed upon the premifes, get the afcendancy over two-yearold feedlings, which were imported, and put into nurfery the fame day the feeds were fown; fo that it is much better to wait patiently for the coming round of the plants raifed upon the fpot. The truth of this affertion I hall fubmit to any of our great planters, who are in the habit of importing feedlings, and have alfo eftablinhed feminaries of their own.

What is here advanced is principally with refpect to feedlings imperted from Scotland and the north of England; as I would by no means have it underftood, that there could be any material lofs, in point of time, fuftained by purchafing feedlings from Irifh nurferies, when fituated at a reafonable diftance, and when care be taken in packing, and difpatch ufed, between the times of taking up the feedlings, and pu:ting them into the nurfery, or, what anfwers fully the fame end, tha moulding 
moulding of them fecurely till put out. Between thefe, and plants raifed from the feed in the planter's own nurfery, there will be found very little difference, provided the qualities of both are equal; this I know from long experience.

SEcT. 2. The general Plan of fettling the great outlines of the Demejne and its appendages.

Having fettled the general plan for feminaries and nurferies, the next care was to afcertain the great outlines of the demefne, with the appendages and interior plantations.

'This was not the work of a day; many days and hours were fpent on this fpeculation, with clofe application and intenfe ftudy. At length the general plans were fettled, and the work went on regularly and pleafantly.

The demefne contains about two thoufand Irih plantation acres, with many confiderable appendages. It was alfo in contemplation to plant between three and four thoufand acres in ftrong maffes throughont the eftates. Though the latter was fettled, and reguJarly regiftered, yet it was only intended as a fock to work upon, when a great redundancy of nurfery-trees sould be fpared from the improvements of the de. mefoc, 
mefne, \&cc., or when the works of the demefne fhould be brought to fuch perfeetion, as to be able to undertake the intendea plantations throughout the eftates.

At this time (1802) the demefne and its appendages are fo far advanced, that the planting of about fifty acres would complete the whole, and this in grouping and fender plantations, as finihing touches, the great maffive planting being all completed.

It is not eafy to fay with accuracy, how many acres there are of folid planting, as every feafon there are more or lefs planted, which never fall within the premium planting, or that reported to the Dublin Society. $I$ am fure I may not be far from the truth if $I$ fay five hundred acres; though, by taking a fuperficial view, it would appear as if one half of the whole extent had been planted; but this circumftance is owing to the fwelling and undulating difpofition of all the grounds, both in the demefne and its environs.

This account may ferve to thew, what induftry and perfeverance can do in a fhort time. Twentytwo years back, from the prefent year (1802), may. be confidered the commencement of the improvements; and, for progrefs, and high prefervation, I am fure they are equal to any in the united kingdom. Raifing fhelter, judiciouly improving the foils, planting out young, and adapting the plants to the foils and afpects, were the great objects to attend to, and which were the principal means of the rapid progrefs, 
progrefs, made by all the plantations belonging to Lord Mountjoy. But I need not have faid any thing with refpect to the progrefs, as this point fufficiently proves itfelf.

During the above period, I can to a certainty declare, that it did not exceed five pounds to make any alteration or deviation from the general plan, firft digefted and arranged. Hence the good effects arifing from fetting out upon a cool, mature, and deliberate plan. I win the fame could be faid, with propriety, of all the improvements throughout the kingdom.

The nurferies, \&c. being fettled, there was no time to be loft for enclofing, and preparing the foils intended to be planted. It was a general rule to enclofe and plant the higheft and moft expofed fituations firft, which are chicfly the went, fouth-went, and north-weft, thefe being the points moft neceffary to guard againft. Another rule was much attended to, namely, to enclofe fome time before the planting took place, and alfo, to drain, where the foil required it. It was very common to enclofe and drain for three feafons before the planting conmenced, by which means the nature of the foils was cntirely changed; Melter and draining laving acted fo powerfully, and the furze-feeds, fown on the backs of the ditches, becoming complete Melter in three years; and the ftuff, calt out of the drains, went 2 great way in deepening the foil. But more of this in its proper place.

SEct. 
SEct. 3. Modes of enclofing.

๘. Common ditches.

2. Louth fences.*

3. Sunk fences.

4. Drains in boggy and fwampy fituations.

5. Living fences, without a gripe or a trench.

6. Temporary dead fences, made principally of Scotch fir, cut down at the age of ten or twelve years.

7. Common paling, by poft and rail, and by theephurdles.

I. The common ditch is chiefly adopted for all the interior parts of enclofures and plantations. The gripe is generally feven feet wide at top, and two feet at bottom, and, where the foil will bear it, five feet deep on the perpendicular. An off-fet or fcarcement $f$ is always introduced, from fix to twelve inches broad, according to the nature of the foil, or the pofition of the bank; if the ground falls away from the bank, fix inches for off-fet will anfwer; if the reverfe, twelve inches are generally allowed; and, if the bank be on level ground,

or

- So called by the writer, from a fpecimen feen by him, many years ago, at Rofy Park, in the county of Louth, upon a fmall fcale, but executed in a neat and workman-like manner.

. A common phrafe in this county for $2 n$ off-fet. 
or nearly fo, between fix and twelve inches are ufually left.

Upon a great fcale, the expence of weeding ditches, for three or four years after they are made, becomes very confiderable; this expence is in a great meafure faved, by introducing a courfe of ftones from fix to twelve inches high; but, previous to this, all the vegetable foil of the off-fet, and, alfo, the foil to the thicknefs of the courfe of ftones, is caft back, to be convenient to bed the rosts of the thorn quicks in. Another fmall courfe of ftones is generally laid over the quicks, after being fecurely bedded in good foil. By ufing thefe precautions, and always planting ftrong thorn quicks, never lefs than four years old, having been two years tranfplanted into nurfery before they are put into the ditches, the expence of weeding becomes next to nothing; and, even if the whole face of the bank hould moulder away by the weather, the quicks are never injared, as the ftones effectually fecure the roots, which, in the common way of ditching, without off-fet or ftones, never fail to be materially injured.

The only objection people in general have to this kind of ditch, is, on account of cattle, particularly meep, being able to walk along the off-fet; a few ftones, laid on the off-fet, may prevent this, or, for want of ftones, a night bearding of brufh-wood of any fort. A better hedge is obtained in two years, by planting four-ycar-old quicks, than caa be in four years, by 
only planting two-year-old quicks. Timber-trees are feldom planted with quicks in the demefne.

The thape of the ditch, when finihed, is thus."

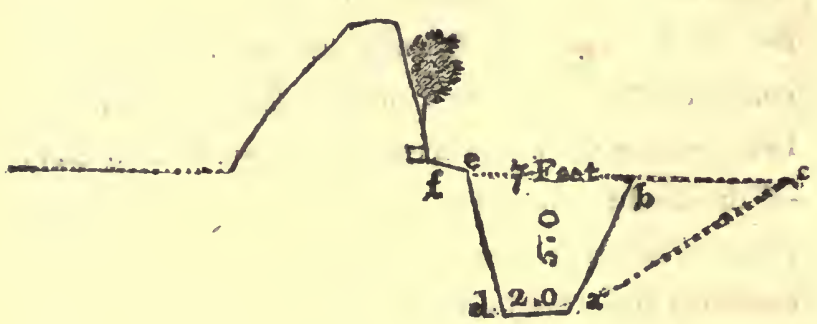

In a few years, when the hedge becomes frong, which is moft commonly the cafe the third year, the fpace $a, b, c$, according to the line $a, c$, is noped and dreffed, and fo is the bank $d, e$, to the ftone-courfe at $f$. Both nopes are dreffed with the fward, between $b$, and a, and fwarth borrowed from any neighbouring fpot; but, when the fward is fcarce, hay-feed will anfwer; it is common to ufe the fward on the face of the bank from $d$, to $e$, and fow the flope, $a, c$, with hay-feed.

This mode always produces a good effect, and it is very evident it is economical. It is chiefly confined, however, to where the foil is difpofed to wet or moifture; for, where it is perfectly dry, and there is no hazard in filling the ditches, the hedges are cut down

at

* Coft from 2s. to 2s. 6 d. by the running perch; and, when the floping and dreffing takes place, the price by the perch is from $4 d$. to $6 d$. 
at once, after they have attained to fufficient ftrength, and the banks levelled in. The dead thorns are placed to the front of the quick-line, about two feet from it, which effectually fecures the young growth from cattle, till it becomes fufficiently frong, which is mont commonly the cafe in two or three feafons. This anfwers very well, where there is no temptation to carry off the dead thorns for fuel, but here turf is in great plenty. In placing the dead hedge, it leans fomewhat outwards from the living hedge, which makes it more fecure againft cattle, and admits of more air, as the living hedge advances; a circumftance which fhould always be attended to, from the moment the hedge is cut down.

In fome infances, hedges have been cut down within about three feet of the furface, and the fideIhoots of what remained worked in to thicken it. I am not an advocate for this fy-fem, as a complete fence afterwards is with great difficulty infured, fince a re. gular taper-fahion, from the bottom, cannot, without much trouble and expence, be accomplifhed; whereas, by cutting down the hedge at once, all this inconveniency is avoided, fince the young growth may be eafily managed, and kept within bounds. However, where perpetual fences are neceffary, which, in pafture and meadow grounds, muft be always the cafe, and where there is a hazard of carrying away the dead hedges for fucl, the cutting down of hedges, at a cer- 
tain diftance above the furface, feems to be the molt rational mode.

2. Louth fence.-Inftead of a wall, built of lime and ftone, this fpecies of ferice has been adopted feveral years ago; firft, on account of its being one-third cheaper built than a wall; fecondly, it can be executed by common labourers; and thirdly, as it may be planted with thorn quicks when found neceffary.

It was calculated, that a ftone wall, of eight feet from the furface, would coft $2 l .8 s .3 d$. by the running perch. Upwards of two miles of the Louth fence have been made, and the average did not exceed $16 s$. by the running perch. In a circuit of between feven and eight miles, which is about the extent of the demefne-fence of Rafh, the difference between $16 s$. and $2 l .8 s .3 d$. amounts to a large fum; but the applying fo much money among the labourers of the neighbourhood, inftead of mafons indifcriminately collected from many parts, was an object of confequence to the labouring poor, which the ever to be regretted late Lord Mountjoy never loft sight of. 
The under fketch may ferve to give the reader an idea of the manner of building this kind of fence :

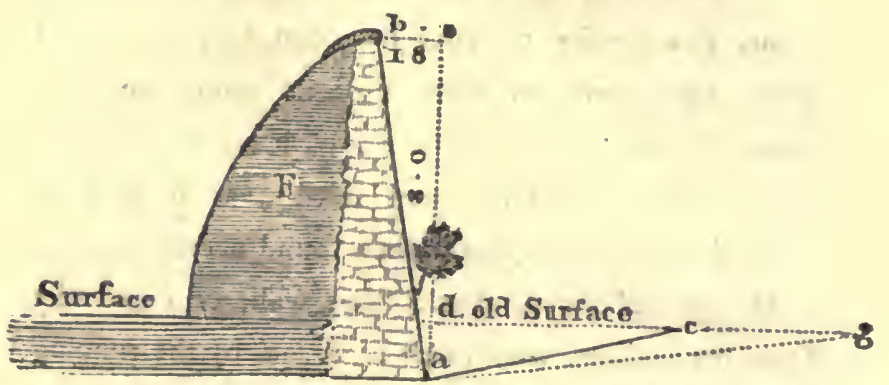

2. 6

To every foot in height, there are two inches and a half of a batter or flope, in the face of the ftone work from $a$ to $b$, making in the whole one foot, eight inches, from the perpendicular; the thicknefs of the wall at bottom is two feet fix inches, and reduced to about ten inches at top, which is always covered with 2 fod, to project a little over the face of the wall, and may be produced to any lengtb down the bank, or the back $F$.

If the triangle $a d c$, be not found fufficient to form the bank F, the ground may be excavated further to $g$, or towards it.

This 1ketch is reprefented as if built on level ground, or nearly fo. When the ground rifes bold behind the fence, lefs ftuff will be necefrary to form the back, and vise verfa. The cheapent way of building thefe fences 
is, when they are placed againft the hill, and in fuch fituations there is no hazard of finihing them off at once; but when the whole of the back muft be formed, as is the cafe in the annexed. Rketch, two feafons are neceffary to complete them, in order to give the mould time to confolidate.

The greateft care muft be taken in building this kind, of fence by a frame or gauge, which muft be reduced on one fide, and perpendicular on the other; or, if the back part of the frame leans a little from the perpendicular towards the wall, it will be found fill better. But the fafeft manner of building this kind of dry wall is, to have the frame in two parts, one four feet high, and another about three feet, which, with a double courfe of fods, will raife the wall to nearly eight feet, which is the height ufually adopted here. In making the gauges, the beft way is firft to make one to the full length of about feven feet and a half, and cut it after to the lengths required; this will be found the moft accurate way. A range four feet high may be firft carried on to any length, and afterwards come on with the fecond range, in which the frort gauge is to be ufed. 
Perbaps the under fketch may ferve better to explain this, than all I have faid.

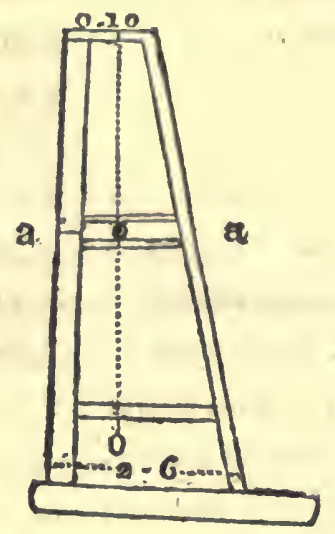

After the frame be made, it may be cut at $a, a$, which is the fureft method to have it made accurate; however, where the back requires but little fuff to be caft to form it, and that it is intended to finin off in one feafon, the frame may be left of the whole length, and, in that cafe, one of the crofs bars at $a, a$, may be omitted. In any cafe, the workmen will prefer the hort frame, as it is move manageable than the other.

From what has been remarked, the fituation muft always determine the depth of the ground to be cut away; in proportion as the bank rifes behind the wall, the more cutting will be neceffary, and the lefs filling will be required. Where the fituation is level, or ncarly fo, two feet below the furface is the ufual depth 
to fink for the foundation, and the ground afterwards noped fo far as may be found neceffary to form the bank. I by no means advife that any ftuff mould be collected from behind the wall, to affift the forming of the bank, where there might be any hazard of injuring the foil when intended to be planted, or that it had been already planted, which here is almoft univerfally the cafe as far as this kind of fence is completed, or where it is intended to be introduced.

At Rafh the planting has gone on fo rapidly, and particularly on the weft and north-weft afpects, where the Louth fences are principally adopted, that to wait for the completion of them would keep the plantations back, and retard their progrefs. Common ditches were therefore adopted and introduced, exactly in the direction in which the Louth fences were to run. In this cafe the only object was to form a ftout bank, with an off-fet, and quicked as formerly defcribed, without fetting any regard to the depth or form of the gripe, the depth of which feldom exceeds three feet; the reafon of which fhall prefently appear from the following fketch.

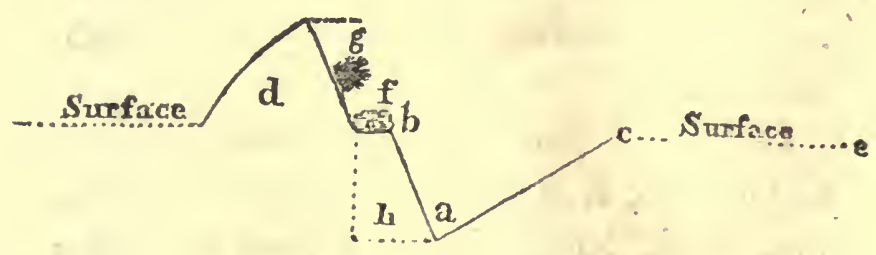


The folid, $a, b, c$, is made ufe of for the back $d$; or as much fuff as may be neceffary may be procured to wards $e$; $f$, flones or bruh-wood to fave the quicks $g$, and prevent cattle from creeping up on the face of the ditch.

After fome time, when leifure ferves to build the Louth fence, the folid lump $b$, is cut away, which admits of a fure and folid foundation for the ftone-work. But, the feafon before this operation is to tale place, in cafe the quicks hould have got too frong, it is necellary to cut them quite clofe, in order to have a soung growth, capable of being bent down in a horizontal direction, to comply with the ftone-work. But when the ftone-work reaches within about three inches of the quick, a thin fod Thould be laid on the ftones; the fame precaution Mould be ufed over the quick, which prevents it from being cut or galded by the ftones either above or below, which would foon be the cafe without taking this remedy. I mould have remarked this precaution before, in building thefe fences, where temporary ditches are not in queftion; but it would naturally occur to any intelligent perfon, who has feen any fences faced with ftone, where the quicks are perpetually breaking off for want of a free circulation of the fap.

For my own part, I am a great advocate for this kind of fence, as an outward boundary to a demefipe. Even without being quicked, it is proof again $\mathrm{ft}$ man 
or beaft, and is certainly lefs fubject to decay than a wall built of lime and ftone:

Befides its cheapnefs and fimplicity, there is another object, fufficient to recommend it. The beauties of plantations and dreffed grounds are, in a great meafure, loft to the fpectator from the outfide of a demefne, by a continued dreary wall, which never fails to tire the imagination, and offend the eye; the Louth fence may be occafionally kept low, fo as in fome meafure to partake of a funk fence; and, if quicking the face be adopted, which I by no means infift upon, the quicks are eafily kept down to the level of the wall.

3. Sunk ferice.-Situated as the demefne is, this kind of fence was obliged to be adopted, and that upon an extenfive fale. A public road of great refort accompanies the demefne for upwards of two miles, which, being common to feveral of the approaches, and being fortunately placed fo as to give no offence, or in any part of it to appear a nuifance, was of courfe continued, and widened from the original breadth to that of fixty feet; ot at lealt it is now fo far advanced, that little remains to complete it.

As the demefne lies on either fides of this general approach, and the views to the grounds, the river, and the plantations, with many other interefting objects, are fo numerous and exquifite, that it was judged unpardonable to conceal any object, that could be Mhewu to advantage, funk fences, therefore, were

$$
\text { Q.2 adopted; }
$$


adopted, and have been already carried on to a confiderable extent, and are at prefent in a progreffive State.

Hitherto the expence of the funk fence, was found to be nearly the fame, by the running perch, as that of the Louth fence, namely, about 16 s., divided as follows; 4s. for the excavation, ros. for ftone-work, which includes quarrying, drawing, and building, and 2s. for תoping, drefling, and fodding.

In feveral parts, fmall bogs and quick-fands occurred. In fuch places, great precaution was neceffary to fecure the foundation, which was done by bedding ftrong hurdles, made principally of oak, under the ftones; the hurdles are commonly four feet broad, and the centre of the wall is always placed on the centre of the hurdle. The largeft ftones are made choica of for the foundations, both for this and the Louth fence, and more particularly fo in foft foils, or where thęre is any hazard of one part fubfiding more than 2nother. Another precaution was found neceffary, both in cafes of Louth and funk fences, namcly, two feafons ate allowed to finith the ftone-work, where the foundations are not good, or appear doubtful. The wall is generally raifed three or four feet high the firlt feafon, and the year following is finithed off. It

- was alfo found necefrary to leave a fmall fpace unbuilt, at the junction of the firm and boggy foils, as the wall, when built on the latter, was always found 
to fubfide confiderably, and, of courfe, drag the work on the hard ground with it, without being thus guarded. When the fettlements are found to have ceafed, then thofe opens may be filled up, but not till then.

The reducement, or batter to the front, is the fame as that allowed to the Louth fence, and the back of the wall is kept perpendicular, or rather inclining a little from the perpendicular towards the centre, as formerly remarked in the Louth fence. Workmen fhould be narrowly watched with refpect to this part of the work; they think, when a fair regular fection is made in the bank a confiderable way, that it may be fully fufficient to guide them; and that, if the ftone-work fhould even lean a little towards the bank, fo as to pafs the perpendicular, no material accident would take place; I know, however, from experience, that, in the hardeft and firment foil, this practice cannot be depended upon; fo that the gauge and plummet muft be always attended to.

So much for funk fences in point of ornament; or rather (here), as to their admitting to view innumerable ornamental objects, which, by adopting any other mode of fence, would be for ever loft, at leaft in fome meafure.

In the inclined plane, this fence differs fomewhat from the common funk fence, by which means it is found more difficult to afcend, which is the great point to guard againft.

The 


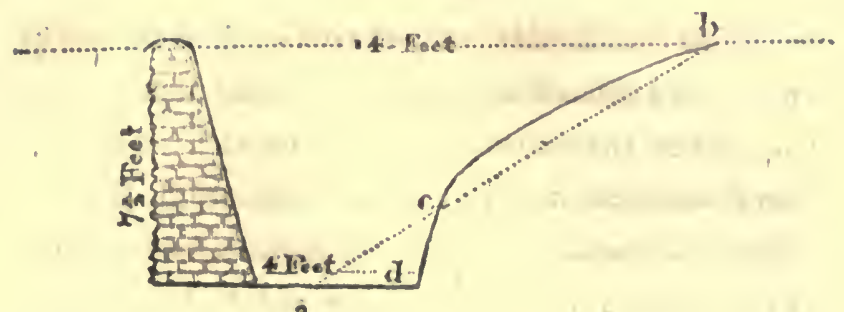

8

The flope of the common funk fence is ufually made according to the dotted line, $a, b$. It is plain, that a perfon has more power to get over the fence from the plane, $a, c$, than from any part between $c$, and $d$; becaufe, in the firft infance, the perfon, would naturally take advantage of fome part between $a$, and $c$, to ftep from; but any part of the fpace between $c$, and $d$, is too remote from the wall to extend the legs.

There are a great many funk fences of fmaller dimenfions, to turn cattle only, already completed throughout the demefne; fome in ast of making, and others in contemplation. No ground can be better difpofed, to favour funk fences, than thofe of Lord Mountjoy's demefoe. With other early regulations, thofe of funk fences, to divide the grounds, both for profit and beauty, were not forgotten. All this was found neceffary, previous to determining the various interior plantations, as, by fo doing, fome expence might be faved, in curtailing the length of the line of the funk fence, by projecting or making ftrong prominences in the line of planting, without in the leaft infringing on the line of beauty. 
To divide the whole of the dreffed grounds of the demefne, will require near one thoufand running perches of funk fence, at 125 . a perch. What has been completed coft about that fum. The general dimenfions are; height of wall, fix feet and a, half; extent of excavation, from ten to twelve feet.

Here it is a very pleafing circumftance, that in all this great fcene of dreffed grounds, when completed, and divided by funk fences, not a fingle bridge, or other contrivance, to lead from one divifion to another, will be found neceffary, fo as to crofs the fence. Each extremity of every funk fence has fallen, or is intended to fall, in with fome plantation; fo that the communication, from one divifion to another, is carved out through the plantation, in a curvilinear manner, fo as to conceal the gate, which is always placed at the mort prominent point of the curve.

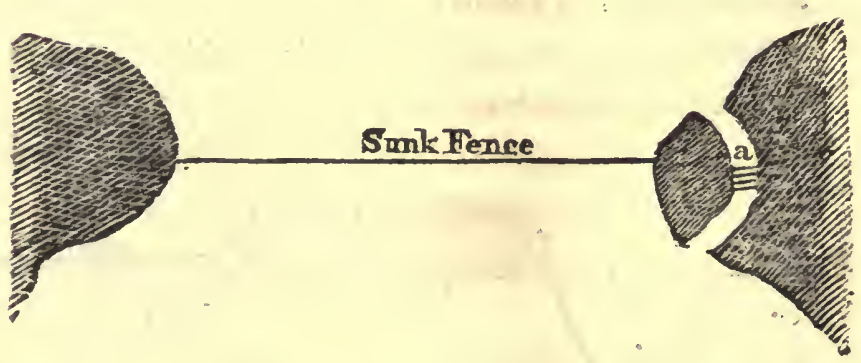

$a$, The gate, made in the moft fimple manner, of a few an rungs, not much ftronger conftructed than a sheep-hurdle, but made fo wide, as to admit of a load 
- of hay or corn. Sometimes advantage is taken of fome trce to hang the gate to, and it not unfrequently happens, that another tree may correfpond to mut it to; and there have been inftances of trees falling in to anfwer for heel-polts for the gate.

4. Drains as Fences in boggy and fwampy fituations.Where it may be neceffary to introduce fences of this defcription, they muft be done with patience and caution, as, if performed the firft feafon, they feldom fucceed, being fubject to hip and give way at the fides, and to fwell upwards at bottom.

The ufual mode here is to fink them about two feet and a half the firt feafon, which is moft commonly done in fummer weather. The weight of the fuff, thrown out of the drain, ferves to prefs out the water of the fpace under it, and thus by degrees it becomes folid. In many cafes three feafons are found neceffary to accomplifh this bufinefs.

Thofe fences are generally made double, forming . betwcen a fpacious bank thus.

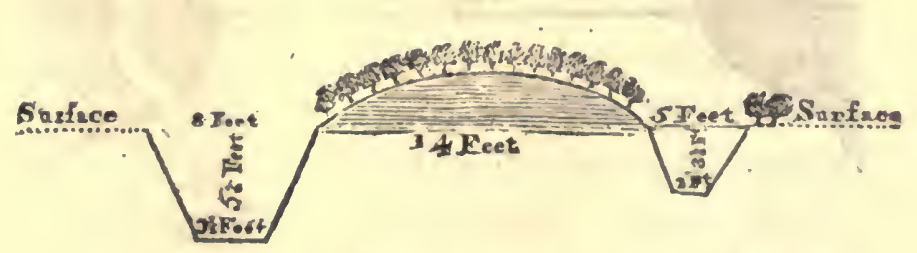

By thus intercepting the water on both fides of the bank, it in fome time becomes folid, and fit to nourigh 
trees, chiefly alder, birch, mountain ah, and woolly poplar, all of which are extremely ufeful for the country.

Not more than from a foot to eighteen inches in depth fhould be calt on the furface of the bank; in cafe it be a fpongy red bog, more would-render the whole a caput mortuum. Befides the ufe of the ftuff calt on the bank, for the purpofe of prefling out the water, it alfo ferves to rot the furface, and render it more capable of nourining trees, than it would otherwife do, and to render the whole more fertile; all the furfaces are made to meet, that is, the furface of the bank, and thofe of the drains.

By computing the area of the 'drains, and the folidity of the bank, or the ftuff caft up, it would appear, that, at eighteen inches deep, the latter would only be equal to about one-half of the former; experience, however, proves the contrary; fo fubject is all fpongy bog to be reduced, when divefted of the fluid, which, for the greater part, compofes it.

The reader will pleafe to obferve, that the inner fides of the drains are more floped than the outfide ones; the reafon is obvious, as they have a greater weight to fuftain.

Two hillings a perch is the ufual price allowed for the large drain, and eight-pence for the fmall one.

Furze has been found to fucceed in thofe banks, when they become fufficiently dry, but rooted plants anfwer 
anfwer better than the fowing of the feed. Thofe of two years old are always to be had in great plenty from the backs of new ditches, where they are moft commonly too thick. Furze, in fuch fituations, not only ferves the purpofe of melter, but alfo has a great power of abforbing the crude juices.

It is farcely neceffary here to mention the preparation of the foils infide of thofe banks for planting, as that does not belong to the prefent fubject, and Ihall be taken notice of in its proper place. I thall only remark, that the interior parts are carved out into a number of quarters by drains, the ftuff taken out of which is always caft on the furface, for the purpofe of rolling it, as in the former cafe, but not near that depth, perhaps not more than three or four inches, as the cafe may requirc.

It is, however, of the utmolt confequence to the future profperity of the whole of the interior planting, to fet about early and vigorouly with the fences, and outfide planting, which here I thall call a belt or fcreen, to fecure and bring forward the other parts.

5. Living Fences without a gripe or trench.-By living fences I mean fuch as form a fence at once, planted on the furface, which are principally adopted in the beft finithed parts of the demefne, or in fituations, which may forbid common ditches, or any fpecies of clumfy fence. At Rafh thefe are numerous at prefent, and are intended to be carried on to great extent. 
For this purpofe the common white-thorn is chiefly preferred, of which regular nurferies are every year formed, fo as to have always a fucceffion, as the demand is conftant. Here it is common to plant two fucceeding crops of potatoes, after forming a plantation; this is generally performed by labourers, and for their own ufe, in fituations convenient to them. . After this treatment, the foil muft be in fine order. The fecond crop of potatoes is generally drilled. The ftrongeft two-year-old quicks are made choice of, and put out in lines at about four feet apart, in a meandering manner, to avoid the trees. Here the plants commonly remain three or four feafons, but the firf, and fometimes the fecond crops of potatoes or cabbages are planted in the intervals, which is always in favour of the quicks, and alfo of the plantations. By the time the plants have ftood three or four years in the nurfery, they.are generally four feet high, which is about the height wihed for. Hence it is plain, that little or no expence attends this practice, as the labourers manage it, on account of the crops. A few Atraggling Ahoots annually clipped off, to give the hedge a taper habit, is the only expence, from the time of planting the nurfery, to that of the hedge.

One thoufand quicks will go over fifteen perches, and, at that diftance, will form a very clofe hedge.

One 
f. s. $d$. One thoufand quicks I fet down at - 033 Digging and preparing fifteen perches of a trench,

Raifing, carriage, and planting, - - $\quad 34$ The value of the feed, and trouble in feminary, planting, nurfery, \&c. - $\frac{026}{6.011 .7}$

This fhews at a view, which I am fure I have overrated, that fifteen perches of a complete fence may be had at once for I Is. $7 d$.

This fyftem, once eftablined, and regularly kept up, is well known to have cheapened the article fences to a great degree.

Honeyfuckle and fweet-briar are always mixed with thefe hedges; a circumftance not fo eafily complied with in making common ditches.

But here there is another refource for forming hedges of this đefcription in a more expeditious mánner, but not altogether fo cheap.

In going over extenfive chains of plantations, it often happens, that the whole of any particular chain, or fring, could not be completed in one feafon, nor perhaps in two or three feafons; in fuch cafes, to fecure every feafon's planting, crofs fences were neceffary to introduce, though for only temporary purpofes. All fuch fences were planted with quicks, the fame as the permanent fences, with this difference, that no 
ftones were introduced at bottom. The object, in introducing quicks in thofe temporary fences, was, in order to have them ready trained, and farhioned for hedges in the courfe of a few years, when the ufe of fuch fences became unneceffary. The fact is, that hedges, thus raifed, anfwered the fame end as if they had been raifed in a regular nurfery, and at fomewhat lefs expenfe.

But, in order to eftablin the roots equal to thofe; raifed in a regular nurfery, the backs of the ditches are in fome meafure cut away, fo as to be able to get: at the roots of the quicks, which are cut with a fharp inftrument within about a foot of the ftem, and then two or three inches of frem mould are put over the roots, -which caufes them to throw out a great number of additional fibres. In this fate the plants remain for two feafons, by which time they are generally furnihed with roots and fibres in as great perfection as they could have been in the beft managed nurfery.

In fome inftances, where the foil is dry, and thelter is not effential, the ditches are levelled at once, and the roots cut and prepared as above ftated; but, without thofe advantages, the firft method is always practifed, fince the part of the bank, left unlevelled, affords fome fhelter, and, by leaving the gripe open, keeps the foil in the ufual medium of drynefs. 
In order to fecure ftrong and durable hedges, to form fences at once, another expedient has been often practifed with fuccefs. The demefne originally abounded with finall farms, many of which were well planted with white-thorn and fome timber-trees, and, very fortunately, almoft all the ditches were either curved, or otherwife meandered, fo as feldom to appear ftiff or formal. In levelling thofe ditches, many' of the timber-trees and old thorns were of courfe fuffered to remain. Indeed the whole of the latter was left undifturbed at the time of levelling the ditches, and their roots prepared by fhotrening them, and ufing a large portion of rich foil to excite pleaty of new fibtes.

Such thorns, as were judged proper objects to ftand for laren plants, were frot touched or doczored*" at the roots; the tops were only lightened, and fo fahioned, as to give them a propenfity to fpread, which requires both fkill and pains, and a little $\mathrm{pa}$ tience. But fuch thorns, as were intended to form new hedges, were cut down within three feet of the forface, and, in two feafons after, were formed into hedges, with as much fafety as plants of four or five years of age regularly raifed in a nurfery. Hedges, of forty years fanding, have been thus managed here with the greateft faccefs.

But

* A phrafe of the writer, which he willes to hare underkood generally in preparing large plants for oraament. 
But thorns, thus prepared, anfwered here another material end, namely, the fecuring of fcattered, grouping, or detached trces from cattle. Upon a large fcale, there would be no end to the expence and repairs of common paling, and, even when done in the beft man- . ner, it carries with it a ftiffnefs and famenefs, that never: fail to give offence. Either black or white thorn removes every inconveniency of this nature; and this: fcene is furtner embellined by planting with the thorns honeyfuckle and fweet-briar, a mode generally purfued in forming hedges of every defcription, and efpecially near places of refort.

The fame confideration, of doctoring thorns, natusally led to another; it was foon found out, that every kind of foreft-tree, with care, was capable of being treated in the fame manner; fo that here that fyftem was put in practice fourteen or fifteen years ago, and has been fince carried on, more or lefs, every year, according to the number, that may be neceffary to keep up a fucceffion, or rather to be in readinefs as the grounds are laid down.

The method, principally' adopted of late years, is, to leave a fufficiency of ornamental plants in nurferies at the feafon of thinning them. When left about fix or eight feet fquare, crops of potatoes are occafionally introduced, the neceffary preparation for which fufficiently prepares the roots of the trees for the forego- 
ing:purpofe.. This fyftem, for many reafons, is better than the former.

The method firft purfued was, to felect fuch plants, as were déemed proper objects for ornamental planting, through the plantations, that had been formed fome years before. Oak, fycamore, wytch elm, beech, lime, and wood-maple, are gencrally made choice of ; the height commonly from eight to twelve feet. $-\mathrm{At}^{\circ}$ the time of doctoring or managing the root, the head is alfo attended to, by Mhortening, if neceffary, and cutting away aukward branches, and alfo giving room, fo as to enable the plant to fpread before it be put out for good. But here it is neceffary to remark, that neither the prepared thorns, nor the trees to be protect-? ed by them, hould by any means remain longer than two feafons between the time of doctoring, and that of planting out; otherwife a fecond operation will be found neceffary, which, of all things, mould be avoided.

For a tree of the foregoing fize, with five or fix flout thorns to protect it, a hole of eight feet in dia-. meter is generally allowed, more or lefs, according to. the fize of the roots. Old dociored thorns generally carry bulky roots, on which account the hole requires to be large; indced the holes cannot be too large. When the foil is poor, two or three carts of good earth are introduced. 'Planting, according to. this' snode, almolt univerfally réquires additional foil. 


\section{APPENDIX.}

In countries where thorn-quicks are fcarce, which is always the cafe throughout this county, much might be made by attending to the fuckers produced from the roots cut off, in ftubbing and levelling ditches. Thoufands of fine plants fpring forth from the roots left, and thofe are always produced near where the incifion was made, or where they have been maimed. The more the roots are cut and mangled, the more abundant will be the crop of young thorns. If the roots are cut into lengths of a few inches, and covered with two or three inches of good foil, in a bed or drill, they will produce fine plants; but this is not peculiar to the white-thoro.

To thofe of extenfive experience in country bufinefs, the foregoing hint may be deemed unnecelfary; but, to this county in particular, it may be of fome ufe. Five hundred plants, thus raifed, will reach further in a ditch, than one thoufand feedling plants of two years of age, and will make a completer fence, in a Morter fpace of time. Of this particular many of Lord Mountjoy's tenants are thoroughly fenfible, as they would prefer the fuckers to the feedlings, though they thould be at the expence of collecting the former, while the latter were ready counted to their hand without any trouble or expence.

6. Temporary dead fences, made principally of Scotch fir, cut away at the fize of eight or ten feet, or when it begins to injure plants of more value.-Very strong and formi- 
dable fences, againnt man and beaft, are made of this article. They are now only beginning; but, from the great quantity of fir and other trees that muft neceffarily be cut away, this fpecies of fence no doubt will be generally adopted, efpecially in backward and remote - parts of the demefne, and in the other improvements. I. I call it a chevaux-de-frife fence; it is made fimply :thus. A trench, about two feet deep, and three feet wide, is dug out, in which the trees are placed upright, generally about two feet apart, fo that when the branches are cut, -at about the diftance of eighteen inches from the ftem, they will crofs each other, forming alternately both acute and obtufe angles, and alfo projecting the borri-work at front and rere. The lower tier of borns are always let down below the furface, the better to ftrengthen the fence; and, when the mould is put in, the whole is well rammed, in performing of which much pains muft be taken, left any of the horns should be broken, which would fpoil all.

The under Iketch may in fome meafure affift the reader, in forming an idea of this fingular fpecies of fence.

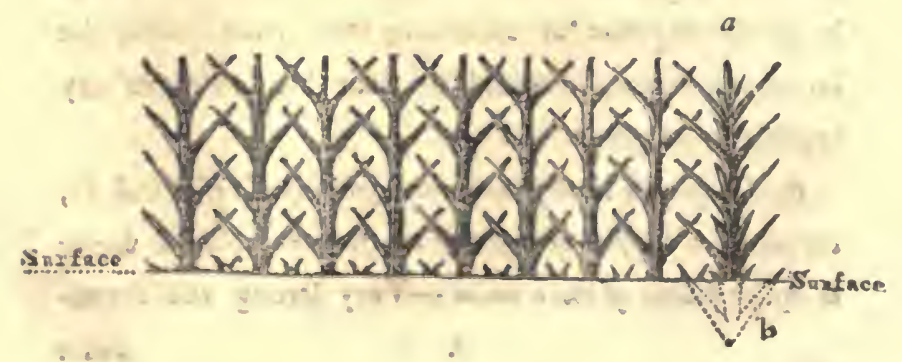

The 
The Scotch fir, $a$, is only reprefented as having the whoie tier of branches, which, in the execution, is the cafe throughout. The dotted lines, $b$, hew the part of the fir under the furface, where part of the lower tier is reprefented alfo below the furface, to keep it firm, as has been already obferved. In fome cafes the whole of the lower tier is below the furface, and when that takes place, the fir is let down to the fecond tier; this is neceffary in boggy or fandy foils, which may be difficult to comprefs.

In forming this kind of fence, the laft two years growth is cut away, being confidered too weak. In general, two years growth is below the furface, and the growth of four or five years appears above it, after cutting off the weak growth.

It is fcarcely neceffary to remark, that the more luxuriant the trees are, the greater the diftance they may be placed afunder, and vice verfa.

In dry fituations, permanent fences of thorn, beech, \&c., of a finall fize, are generally placed behind this chevauxx-de.frife work, which, in the courfe of four or five years, becomes fubftantial enough to guard againft cattle, this being about the period the temporary fence will laft. In moift fituations, alder and mountain-ah are introduced, and, after being two feafons planted, are formed into a kind of hoop, four feet above the furface, which is found to make a complete fence againft cattle, when the other has gone to decay. In 
many inftances, honeyfuckle, fweet-briar, all forts of common briar, dog-rofes, \& $x$., are let in with the temporary hedge; this contraft produces a molt ftriking effect, and, by the time the dry hedge is decayed, thore articles become a mont formidable fence. When this plan is adopted, which munt be always in dry foils, the back hedge is altogether omitted.

On the whole, this is a very cheap fence, fince it is attended with little more trouble than that of planting a common hedge. When hedges are to be formed behind, the beft way is to open the drill or trench, to the breadth of five feet, by which means both the dead and the living hedges may be carried on together, and thus prevent the opening of a fecond trench, which would only ferve to loofen the ground about the bornwork.*

The fuff, ufed in this fence, is not fufficient for ribs for cabins, meep-hurdles, common paling, \&c.; and as it muft be cut away at certain periods, it would, of courfe, go to lofs, to prevent which, the above ufe is found the moft eligible.

7. Common paling of pof and rail, Beep-burdles, Eัc. Except to enclofe corn and hay-\{tacks, turf, \&cc, very little ufe is made of common paling: the foregoing fence fuperfedes it, and is performed confiderably clieaper; befides, the materials, necelfary for a ftrong paling, are fold to the country-people, for cabin. building,

- This phrafe is fometimes ufed inftead of chevawx-de-frife. 
building, to confiderable advantage to the proprietor, and with infinite fervice to the whole country.

Great ufe is made here of Theep-hurdles, not only for folding theep, but for many other puixiofes, fuch as fecuring the noping parts of funk fences, which have been made through dreffed grounds, furrounding old quarries and fand-pits, which require to be filled and dreffed in fome time after the furrounding grounds have been laid down, and where the ufe of them is found neceffary after that operation.

For thefe, and a hundred other purpofes, theep: hurdles are ufed; they are eafily placed up, and foon taken down, when not wanted. Here they are made of oak faplings; it would be only throwing away time to make them of any other young ftuff, which may neceffarily be cut down, as they would laft no length of time. Four fhillings a dozen is the ufual price paid for making them, and a dozen will extend four perches in length.

Several other fpecies of fence might be mentioned, according to fituations and circumftances, but the foregoing are in moft general ufe.

\section{SECT. 4. Preparation of the Soils for planting.}

Many were the expedients made ufe of, to prepare the foils, and promote the planting of the extenfive 
and varied improvements of Rash. The four following I Thall briefly ftate, being the mont general.

I. Soils, that came within the power of the plough, were trenched by the Kentirh wheel-plough, drawn by fix bullocks in the yoke fathion. This kind of preparation anfwered completely fo far; but there was another object in vietw, namely, as the ploughing was performed deep, a vaif number of nones were difcovered and procured, which otherwife would have been for ever loft; by this management they ferved to build a great part of the Louth fence, already fpoken of.

There were about fifty acres of this defcription prepared for planting. The operation, it is true, was tedious; I dare fay not more than a rood of ground daily was ploughed. 'The plough was attended by fix or eight able labourers, befides the ploughman and driver: The men were provided with long oaken poles, fhod with iron, which ferved as levers to turn out the rocks, which the plough difcovered. Crowirons were ufed for raifing the fmaller ftones. All ftones, that appeared above the furface, were previounly taken up, and carried away before the ploughing commenced.

Upon the whole, this was found a cheap mode of procuring ftones, as the parts where they were ufed lay very convenient. Had the diftance exceeded a

mile, 


\section{APPENDIX}

mile, this plan would have been given up, as ftones regularly quarried would have come cheaper.

There is at this time a very material difference between the growth of the trees, where the foil was thus treated, and in fimilar foils, which had no preparation at all. It is at leaft as the proportion of ten to fifteen: in favour of the trees where the land was ploughed; that is, trees planted ten years ago, where the foil was, prepared as above, are now (1802) fully as forward as. plants put out fifteen years back, without any preparation. How long this great afcendancy may continue: to prevail, time only will tell.

2. Large fcopes of dry, hungry, Mallow foils; fome almoft covered with broom, furze, and other fponta* neous growths, in a ftate of nature. But the greater. part was formerly occupied by little farmers, who knew: that their inheritance was only to be of Mort dura. tion, and, of courfe, worked out the foil to the loweft. ebb.

To trench or plough foils of the foregoing defcrip? tions was thought unneceffary, as that, of -courfe, would only. render them ftill lighter, and, confequently, unfavourable to planting.

In the "firft cafe, clofets were formed through the native bruffi-wood, of different mapes and fizes, fo as to contain from ten to thirty plants, more or lefs, at about three feet apart, and often nearer, but fcarcely ever to exceed that diffance. Five thoufand plants to the acre are 
not uncommon in fuch lituations, where they are high, and much expofed to the weft, \&c, which, indeed, is generally the cafe throughout all the elevated plantations here. In thore high fituations, larch, beech, and Scotch fir are principally made choice of, and in all fituations oak is never omitted, though in the dry hungry ones it gets on tardily for fome years; but, through time, when melter becomes eltablimed, and the foil rendered firm and compact by being at reft, it is furprifing to find how rapidly the oak will get on; it feems fuddenly to appear, after a certain period, as by enchantment.

The natural melter, afforded here, required much attention to make it ufeful, without becoming injurious to the young plants: it was neceffary to have them narrowly attended, and to cut away all fraggling moots of the fpontaneous growths, that might whip, or otherwife injure the young plants. This wcrk rhould never be omitted before the commencement of the autumnal ftorms, at which feafon plants are apt to fuffer moft by the intrufion of their encroaching neighbours, which Should never be fuffered to gain the afcendancy over. the new-planted trees; otherwife all is loft without redemption.

In four or fire feafons the young plantations generally out-top the native growth; but it is neceflary for fome time longer to keep down the bryth-wood, for, 
fo long as it finds air, it will get forward, and caufe the lower parts of the young plants to become naked; fo that the true way is never to fuffer the fpontaneous plants to get a-head in the clofets; and the margins, left for Thelter, may be taken away by little and little; as the young trees can afford. The nearer the Scotch fir are planted to each other, the fooner the native plants will difappear; but it is better economy to put in plenty of valuable timber at the beginning, than to depend wholly on Scotch fir, or any other fpecies of pine, except the larch, fince, in time, they make but a poor figure and return, in point of profit, when compared to others.

I believe it is fcarcely neceffary to obferve, that, in thofe and all other expofed fituations, without planting very young, there could be no chance of fuccefs. Oak, beech, birch, hornbeam, fycamore, \&c. never exceed four years, being generally two years tranfplanted. Scotch fir and larch are commonly put out for good at three years, in which cafe they are put into nurfery at one year old; but this fyftem is only confined to the very expofed fituations.

Now that I am treating of expofed fituations, I mall mention a circumftance of fome importance, which occurred a few years ago, and which was the effect of chance, rather than of premeditated fpeculation. 
Some fecdling-beds of Scotch fir grew uncommonly thick and luxuriant the firf feafon. It was judged that, if let to remain two feafons in the feed-bed, which is the ufual timc, they would be of little or no value. The great luxuriance was caufed by a large. portion of turf.ames being ufed in the comport, a hint which has been fince improved upon, and found of infinite fervice for many kinds of feedlings.

A number of beds were prepared to receive the plants, which were intended to be thinned out. The plants were raifed by' a fmall three-pronged fork, capable of raifing only as many plants as occupied about. two fquare inches, perhaps from twenty to forty plants. In Short, about half the plants were taken up in this manner, and the void Spaces immediately filled with good mould. Inftead of bedding out the plants, thus raifed, individually, they werc planted out in fmaller clufters, from four to eight in number, more or lefs. Thefe clufters were placed at about nine inches apart, fome promifcuoufly, and fome in lines; the latter I recommend, unlefs the foil be extremely clean.

The plan propofed was, that the plants bedded out mould be lined out, and formed into a regular nurfery the year following; but behold, when that was attempted to be put in practice, the fcheme failed, for the roots were found to be fo matted and interwoven together, that any attempt to feparate them was found impracticable, without injuring the whole. Of courfe 
they were fuffered to remain for another feafon, when they were put out for good in clufters, without any attempt to feparate them.

The confequence of this fpecies of planting was, that in three years it made a fuller figure in expofed fituations, than planting in the common way had done in five feafons.' In fuch fituations what we want is, to cover the furface as foon as polfible, and, of courfe, create Ihelter, and for both this method is extremely well calculated. It is idle to imagine, that we Thould debar ourfelves from timber in future by following this plan; every experienced planter knows, that, if a feed-bed of any fort was fuffered to go on its own way, a fufficient number of plants would furvive, and kill all the reft; and in the prefent inftance this is fully demonftrated, fince only ane ftem can now be traced from thofe clufters, which were firf planted out here, being only fix years prior to the prefent year (1802).* Since the above difcovery, this practice has been continued here, but is principally confined to Scotch fir, that being the beft calculated for expofed fituations.

One

* This mode has an advantage over the common one, inafmuch as the wind has little or no power of difturbing the plants, they being balanced from the furface for feveral years. The writer never experienced an inftance of any of this cluferplanting (a name which he has adopted) ever yielding to ftorms, whereas thoufands give way' every feafon when put out in the common way, and, in high moift Gituations, are perpetually loofening by ftorm.s. 
One hint begets another. Every kind of underwood may be put out in clufters, or ftrong bodies together, inftead of planting it fingly. Back grounds may be filled, in forming thrubberies; \&c. with ftrong maftes of lilac, laburnum, fyringa, \&c.; and many other ad-' vantages may be taken, where Ihrubs and underwood are plenty.

I am not without fome apprehenfione, that many of my readers will look upon this mode to be a moft novenly one, and; as it were, a wilful wafte of plants. So they may; but then it Mould be confidered, how much time is gained by this method, and how little is the hazard we run; befides, Scotch fir is always a cheap article; ten thoufand plants may be procured from one pound of feed, which in Scotland feldom cofts more than three millings. But to return to the fecond part of this fubject.

On the worn-out grounds, occupied by farmers and Jabourers, there was nothing more to do than to enclofe and plant; as trenching or ploughing, as has been obferved, would only ferve to render the foil lighter, which was chiefly the greateft fault of thefe grounds. Here, in general, melter was to be created, which is ufually done by fowing broom and furzefeeds, fometimes in crooked or zig-zag lines, but molt commonly in patches. The latter mode in general Mould be preferred, as the broom particularly makes a confpicuous mew the fecond year, and, befides the 
melter it affords, gives a warmth and chearfulnefs to the whole during the year round. The violence of the winds is more completely broken by fowing in patches, than in lines, as the melter, afforded by the latter mode, is only partial; the young plants are alfo more eafily preferved from being fwitched by the broom, in cafes of patches, than in thofe of lines.

Though heretofore the practice of fowing furze-feed in'patches has been adopted, yet the end, for which it was intended, had not always the defired effect. It never makes fo rapid a progrefs, or, at leaft, is lefs confpicuous in patches, than on the backs of ditches, in the fame fpace of time. On the back of a ditch it will make a figure, and afford Thelter the fecond feafon; whereas, in patches, it performs little of either in lefs than four years, by which time the plantation generally affords itfelf fufficient melter. The end of anfwering the protection of game is alfo frequently defeated, and efpecially where Scotch fir is thickly planted, which, in high fituations, is here always the cafe. So foon as the Scotch fir begins to meet, from that period there is an end to any advantage arifing from furze fown with a view of Inelter through plantations; fo that, on the whole, broom hould be preferred for temporary helter; but on the backs of ditches furze-feed thould be always fown in preference to broom, on account of the great length of time it lafts when regularly cut. Here it is always fown 
broad-calt over the whole of the back of the ditch, fo that one-half may be cut whillt the other part remains for Ihelter, by which means complete Shelter is never wanted. In four or five years after fowing, the part of the furze next the thorn-quicks is commonly cut, which always gives the latter the afcendancy for the time to come. A quart of found feed is fully fufficient for thirty perches broad-caft, but confiderably lefs will anfwer, when fown in a drill.

In this place it may not be amifs to remark, that the Scotch fir, ufually put out in clufters, as ftated in this fection, is mont commonly planted in grounds of the latter defcription, or thofe formerly occupied by farmers and labourers, as not being much fubject to luxuriant weeds, or to fuch fpontaneous growths as the former.

3. Thin, wet, fpouty foils, in general much expofed.

To encreafe the depth of foils of this nature, and alfo to drain and render them wholefome, for the reception of plants, were the chief objects to attend to.

From foils not more than three or four inches deep, with a hard fubfratum, almoft impenetrable to water, little could be expected. Draining was found of little or no advantage to fuch foils; in fome meafure it ferved to carry off the redundancy of water, but very little encreafed the depth of the furface.

Recourfe, therefore, was had to another expedient, which anfwered both ends, namely, draining, and deepening the foil. 
One-third of the furface was ftripped, and laid upon the other two-thirds, caufing the two fwards to meet, the better to reduce them. This encreafed the depth "of vegetable foil from four to fix inches, over which 'two inches more of the fubftratum was thrown up, which gave a depth, for planting, of eight inches. The laft covering not only encreafed the depth, but ferved to give weight and ftability to the whole.

In performing this work, it was of little confequence - whether the furrows and ridges were formed crooked or ftraight; they were fometimes one way, and fometimes the other; the difpofition of the ground always directed the courfes of the ridges; up and down hill, where the land was not over fteep or fudden; but, "where the ground tended abruptly, the direction was always carried obliquely to the hill, the better to prevent the foil from being wathed away.

This mode varied according to circumftances. Where the foil was much difporfed to moifure; the breadth of the furrows was three feet, and that of the ridge fix feet; but, in foils more dry, the breadth of both were encreafed, in order to prevent the drought from taking place too much in the fummer feafon; a precaution "which in many inftances was very neceffary, as nothing could be more effential than to guard againft both extremes.

This work was always performed one year at leaft before the planting took place, by which time the fur- 
faces of both the ridges and furrows were thoroughly reduced, and the ftiff foil, which was caft at top, had the full benefit of the winter's froft and fummer's fun. As this work was generally performed in autumn, it frequently had the advantage of two winters and one fummer, to ameliorate and form 2-good abiding foil, very fit for the reception of plants; confiderably more fo, than had it been planted the fpring immediately after the operation.

Here it may not be amifs to remark, that fpringplanting is almoft univerfally followed; experience having long ago pointed out, that thofe foils and afpects are not calculated for autumnal planting.

Ground, prepared as above, is generally managed for $2 \%$. an acre; being at the rate of $6 \%$ an acre, if the whole had got a thorough trenching, which practice at the commencement took place in raifed trenching," as it is termed. It was, however, foon difcovered, that the raifed trenching became too dry in fummer; nor was the quantity of vegetable foil, that the fituations afforded, applied fo effectually for the nourioment of the trees, in the latter, as in the former cafe. Thefe confiderations, with the great difference in point of expence, gare, of courfe, the preference to the former mode.

The

* Raifed trenching is preferred in wet foils, and the trees are planted without levelling the grouad, and left always in that fate. 
Mhe fourth and moft univerfal fyttem of planting, in mountainous and expofed fituations, was purfued according to the following plan.

Small ditches were made in feveral directions, fometimes crooked, at other times fraight, but moft commonly of a winding difpofition, always taking an advantage of the fituation and expofure. There were three principal objects in view, nâmely, the draining of the foil; the creating of melter; and fecuring a fuffciency of earth to nourifh the trees. The more expored, the nearer it was neceffary to introduce the ditches; but for brevity fake I hall fet down the ave'rage difance at twenty-one feet apart. An acre, according to this diftance, contains 320 perches of ditch; and, by allowing fourteen trees to the perch, the number to the acre is found equal to 4,484 ; one thoufand of which, at leant, were always oak.

Oik, an, and fycamore, were chiefly preferred for the main or permanent timber; beech was fometimes introduced, but this article does not bear cutting, when puit into the faces of ditches, fo well as the foregoing. Inftead of planting alteriately, the different kinds were put in, in groupes; but I thould have remarked before, that great quantities of mountain-ah, alder; birch, poplar, \&xc., were introduced in ftrong bodies between the valuable plants, varying all the articles (except the oak, which was univerfal) according 'to the nature of the foil. 
The order of planting may be eafily underitood from the following Rketch of fout divifions, which I I hall ruppofe equal to four fquare perches:

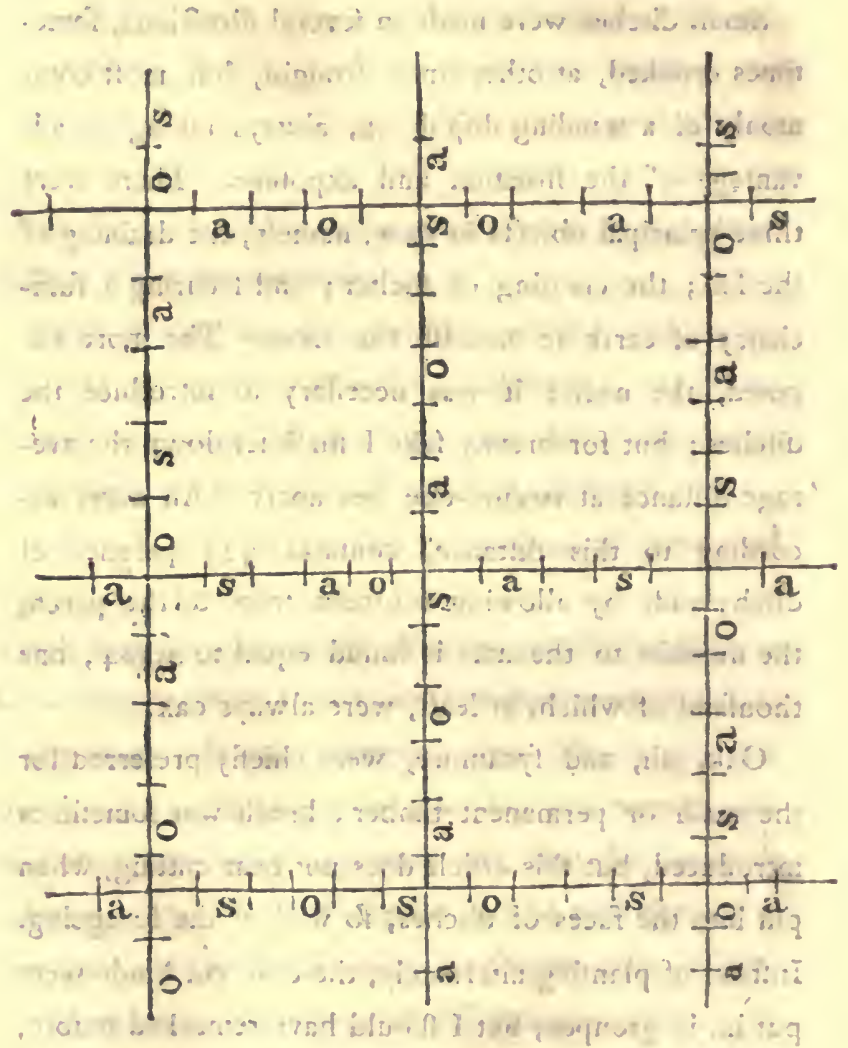

(1.) 0 , reprefents oak, two or three in a group. . :

$a,-a / h$, from three to fix ditto.

$s$, fycamore, two or three ditto.

It is not at all neceffary to be exact with refpect to the inferior kinds planted in the intervals, as they: are 


\section{APPENDIX.}

to be cut a way when they begin to interfere with the others' the more that are put in, the better. Sometimes Spanifh chefnut and wytch elin are confidered among the valuable kinds, but for the former the foil muft be good, and naturally wholefome, which in thofe fituations we feldom meet. An is always put in plentifully, becaufe it is a good article for fale whilt young.

The general breadth of thofe fmall ditches is three feet and a half, and the depth from eighteen inches to two feet, and they are made for $4 d$. a perch, being equal to 5 l. 6s. $8 d$. an acre. The furface of the gripe is fripped, and laid under the quick, with the fward downwards; the remaining good foil is caft over the fward, part under, and part over the quick. This might be performed in autumn, and the ditches may be finifhed in the courfe of the feafon: The ftronger the plants are, the better, as, when cut, the ftronger they will moot; I often planted them fo thick as a walking-ftick. They mould be cut before they are put in, but it is neceffary to go over them again, after the ditch' is finike to drefs and fmooth off any wounds, that they might have received during the operation. The faces of thofe ditches are always fronting the eaft as much as poffible, in order that the bank may afford the more melter. The banks are always fown with broom-feed, broad-cant:

This mode may appear to be expenfive, but I mall prefently thew to the contrary. 
It is about ten years ago fince this fyftem was firft introduced, and fince that time there have been upwards of one hundred acres planted, according to it. From part of the early planting, one thoufand of the inferior trees per acre have been cut away, which fold for $8 \%$. 6v. $8 d$. for the purpofe of Movel and fork handles, which is only valuing them at two-pence each, clear of all expence, but they frequently fell confiderably higher; good ones fell at four-pence each. But the profit does not end here, as the future growth of the timber, thus difpofed of, will for feveral years anfwer many, purpofes, fuch as turf-creels, \&c., for which there is always a great demand. But the thinning of the afh will, in a Mort time, bring more than double the. abore.

It is now clearly underftood, and I am fure that I am under the mark, when I fay, that, in fifteen years, each acre will return 20l, and this by cutring away only fuch inferior ltuff, as would, if fuffered to remain, irrecoverably deftroy the principal timber, which, of courfe, will require thinning in its turn, sut not till confiderable profit may be made of it.

In hort, this is the mont profitable fyftem for mountain planting I know of; and its effects, as being pic turcfque, are already fully demonntrated here. Such planting affumes a fuller appearance in five years, than any other fpecies of planting, in fimilar foils and fituations, would have done in feren or eight years. 
At the time this practice was begun, the idea of planting the clofets or intervals was out of the queftion, the foil in general being fo wretchedly bad; but two or three years made a wonderful alteration in it for the better; and every year, in proportion as the thelter is encreafing, and the drainage effected by the fmall ditches operating, the foil is becoming better and better; fo that thofe clofets are filled up from time to time with more valuable timber, fuch as larch and beech, and fometimes Scotch fir, to enliven the fcene, and afford fome variety for a few years.

It would be an endlefs performance to enumerate the different fecondary modes of planting made ufe of: here, as many of them differ very.little from fuch as are practifed in other parts. My chief object was to point out fome of the mof difficult undertakings, in order to hew what induftry and perfeverance may accomplifh, and that in a few years. But before I take leave of this fnbject, I beg leave to lay before the reader the method followed with refpect to an oak wood, which had been partly on the decline, and, of courfe, was cut down fome years. ago. 
SECT. 5. An account of the management of an Oak wood, avbich had been for , many years on the decline, prior to the year 1792, at which perisd the following febeme was, commenced.

- BETWEEN ninety and a hundred acres of ftraggling oak woods about ten years ago exhibited a miferable picture, being by far the greater part fo far decayed, that the bark could not be fripped off in fummer at the ufual time of cutting down oak; fo that it was a matter of indifference what feafon the trees were cut down at, fince no profit of any account refulted from the bark.

There were various opinions and conjectures, previous to the cutting down; it was almoft univerfally agreed, that, fince the oak had given up, no new fpecies would licceed, the foil being fo dry and exhaufted, and that it was better to let the oak continue in the Itate it was, to linger out its exiftence. Thefe futile - advices were laid afide, from the well known laws of nature, as it is a fact, that. requires but little demonftration to prove, that every plant is capable of fearching for juices mont congenial to its own fupport. It is a very weak argument to advance, that, becaufe the oak declined, other plants fhould not fucceed; the former had abforbed all the nourifhment from the 
foil, that was congenial to itfelf, but left ample allowance of other juices fuited to different kinds of forefttrees, which, fince the above period, is fully evinced from the rapid growth and vigour of every article put out.

As the fituation was very much expofed to the weft, fhelter was a great objeet; on that account all the under-growth was preferved, which confifted chiefly of heath and whortle-berry; but thefe articles being of a very humble growth, and only occurring partially, recourfe was had to another expedient to raife thelter, which was, not to plant for two feafons after the oak had been cut down; that is, that there fhould be two years growth of the fuckers produced from the ftools of the oak fo cut, which, in general, afforded fufficient melter.

Larch, beech, and Scotch fir, were the chief articles put out, as the foil is of a dry hard nature; but at prefent a great number of the latter are cutting away from the earlieft planting, to give room to the larch and beech, which are going on moft vigoroully. Indeed, contrary to expectation, many of the oak, cur down, are out-topping every other kind; thefe, of courfe, are encouraged, and fuffered to enjoy their birth-right.

From a defire of not making thofe tracts too naked of a fudden, at the time of the general cutting, many trees were fuffered to remain, where there was any 
appearance of health; , but fince, this praftice has been found not to anfwer fully the end it was intended for ; the trees fo left made but very little progrefs, and the early planting, even in the fpace of ten years, has already overwhelmed them; and now, when it is abfolutely neceffary to cut them down, there is a great difficulty in getting them through the young plantations; fo that, on the whole, it is much better to cut down all the oak fmack-fmosth the firlt day (which mode is put in practice here of late years), unlefs fome particular reafons demand the contrary.

The holes were always made immediately before the planting took place, as the foil was fo fanty, that, by making them any length of time prior to the planting, it would be found much reduced by the weather, and, from its anture, would reccive but little benefit from the influence of froft. Indeed, of late years; the mode, that is ufually followed in fuch fituations, is, to have two men making the hole, chopping the whole of its contents within itfelf; two more follow planting, and fcooping the mould towards the edge of the bole, fo as to leave a fufficient cavity to receive the roots of the plant. By this means, not a particle of the mould efcapes through the heath and other fpontaneous growths. The furface and under-ftratum of the holes are incorporated together; and, if the feafon mould prove rery dry, the furface of the hole is mulched 
with mofs, which is always found in great plenty upor the' fpot.

- It is needlefs to obferve here, that planting very young muft be preferred; and that clofe attention muft be paid for a'few years to the plants, till ' they get the afcendancy of the native growth; fpring planting is alfo found to fucceed beft.

Perhaps in this place it may be acceptable, ta relate a circumftance relative to the application of lime on the ftumps of oak-trees, immediately after being cut down.

Since the year 1794 , the following practice has been invariably attended to with fuccefs, fo far as time has proved the refult. I thall only mention one fubject, which may ferve for the reft.

In fpring 1794, a ftool, or group of oak, confifting of five fems, all of which were fo far decayed, that there was no chance of the bark ftripping, had they: been left uncut till fummer, at the ufual time of taking off the bark, were cut quite clofe to the furface, or fo near it as the old ftock could bear the operation. One gallon of lime, quite freh (being a few minutes before flacked), was ufed for the fire trees; it was fcattered over the furface of the ftumps, and a few inches round their edges; the whole was immediately covered over with fods, keeping the fward part uppermoft.

The fhoots, which were produced the fummer following, were the mol vigorous I ever faw, even from ftocks 
ftocks in full rigour and prime of life. Nor were they produced about the edge of the ftump, as is ufual in common cafes, but at fome diftance from it: The thoots alfo were produced confiderably fewer where the lime had been ufed, than where it had not, and, of courfe, they grew more vigoroully.

It appears from this experiment, that the frmall portion of fap, which remained in the roots and ftock, was effectually feared ;p, and prevented from being exhaled at the natural time of flowing; as from the moifture the lime foon became incrufted, and acted as 2 kind of cement, and, of courfe, prevented fuckers or young Thoots from being produced, at or near the edges of the ftumps, which is moft common, as atready obferved.

I mention this for the information of thofe, who may be concerned in the management of decayed woods; a circumftance, which has been fairly proved very well worth attending to. The five ftems only took one gallon of lime; a barrel of forty-twa gallons (the ftandard) would go over, by this proportion, 210 trees; an allowance of timber in moft cafes fufficient for a plantation acre.

Mof, or any other moilt covering, that may not be blown off by the wind, will anfwer as well as fods; and, if none are convenient, any mould will do; but, at all evenis, the lime muft be covered, and kept fo.' 


\section{APPENDIX:}

SECT. 6. Of the advantage of fowing potatoes, as a preparative to alfist the Jpeedy growth of Plantations, and alfo, for the moft effectual mode of laying down bad lands to the greatef perfection.

BRINGING in land by fowing potatoes thereon, has been purfued here for many years back, with great advantage and benefit, both to the proprietor, and to the: individuals who derive under him.

Within the laft fifteen or fixteen years, prior to 1802 , upwards of 150 acres have been fown with poratoes, chiefly by the labourers of the demefne; perhaps fifty of the above number of acres were planted, and the remainder laid down.

In the former cafe it is ufual to plant firft, and to fow potatoes immediately after, the fame year, in order that the trees may gain time. The firft feafon, it rarely happens that the foils are fufficiently loofe and meliorated, to admit of fetting the potatoes in drills; therefore the common bed-falhion is adopted; but, inftead of making the furrows ftraight, they are frequently curved, fo as to avoid the trees, and that they may always be fecured within the ridge, the better to have the full benefit of the moifure, and reap. every poffible advantage from the good foil. 
In this pláce it is rather unnecentary to remark, that the plants muft be of a tolerable fize at the time of planting them out, otherwife the potatoe falks would overwhelm thern. I I Inall only obferve, that the trees, when put out, are not lefs than three feet in height, and that very few of the pine kind are planted in thofe cafes, except larch, which is not fo fubject to fuffer in the foliage as the other fpecies are.

The fecond, and fomctimes the third and fourth' years, it is ufual to drill out potatoes, in, the fame foil where they have been bedded or ridged out the: fitft feafon; nor is it uncommon to have a crop of turnips the laft feafon, which generally fucceeds very well. ?

It is needlefs to remark how rapidly plantations, thus managed, get on; but this fyftem muft be con-' fined to particular fituations; in expofed ones it cannot be put into practice, as, by keeping the foil loofe for fuch a length of time, it could not be friendly to. young plantations, from what they muft fuffer by ftorms. In ftrong abiding foils, not much expofed, this mode can only be introduced to advantage.

In the fecond cafe, or that of preparing land for laying down by fowing potatoes, experience has fully evinced the great advantage of it in this demefne, and efpecially on coarfe, boggy; and marhy foils, whero this mole of preparing them for laying down is generalig and fuccefsfully followed. 


\section{APPENDIX.}

The ufual mode is this. After the fuperabundant water and frings (if any) are cut off, a certain portion of the furface is burned, to affif in the manuring for potatoes; indeed yery often the crop entirely depends upon the quantity of alhes fo procured, without any affiftance from other manures, and generally yery plentiful crops are produced the firft feafon. Two fucceeding crops of potatoes are al ways taken off ; the fecond crop is generally drilled, and, of courfe, a fmall portion of manure ferves; but this manure is commonly compofed of rich-mould and dung; alnes, being feldom ufe the fecond feafon, and efpecially where they bave been ufed the preceding year, as it is well known they are too exhaufting upon foils, if copiouny applied, from the great propenfity they have of abforbing the native oil from the foil.

Oats is the ufual crop to lay down with, with plenty of hay-feeds, chiefly of the wbite meadoru kinds, which are found to thrive best, and laft longent, in mont of thofe foils.

For the firf crop of potatoes the labourers are not charged, but for the fecond crop they pay at the rate of forty nillings an acre. The crop of oats the third year is worth $4 /$. an acre, clear of all expence; , fo that this brings a yearly profit to the proprietor, during the operation, of thirty . hillings annually, allowing an an'nual rent of ten hillings an acre for the original value of the land, had it not been brought into a courfe of 
culture at all, which, indeed, is rather highly rated. Lands of this defcription', after being laid down, let from two to four guineas an acre for meadow:

"In deighbourhoods thickly inhabited, as this is, there can be no doubt of 'being able to procure people fufficiently numerous to fow potatoes every feafor upón a large feale; and had this mode been adopted twenty jéars ago, "about the time of the commencement of laying down the grounds; many pounds would have been

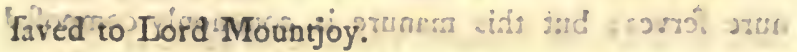
- In lands of the for going defcription, this mode is the cheapert, and moft effectural to bring them into a profitable ftate. IEven in the very beft foils, I rm confident that the taking off two fucelfive crops of potatoes will'always be found the beft economy, both for the proprietor, and the community at large. If this ryfem was fully afid univerfally eftablifhed, there could fearcely be any danger of the poor fuffering, or experiencing the like diftefs they underwent in the years I 800 , and I 801 ; nor could the country be overfocked with potatoes at any time, if the feeding of caitle with them were more univerfally adopted. If the poor man had fix or eight barrels of potatocs to fpare, from the ftock genierally allowed for his family, how, better could they be applied, than for the fupport of his cow, and efpecially in thofe parts, where fodder is moft cominonly very fcarce? 


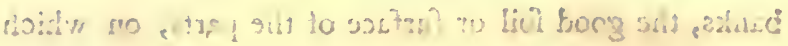

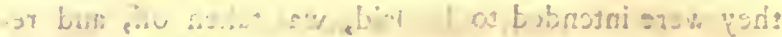

SECT. 7. A defcription of the management of the banke of the river at Rafh, fo far as it accompanies the desnefne, 1, an extent, including all its quindings, of nearly two miles and a balf.

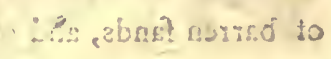

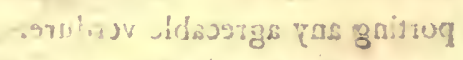

Fif SiEvaral years ago this wcighty bufinefs wast undertaken 5 ras is was forefeen that, unlefs the impedinents, - which obftructed the rengular courfe' of the water' were removed, the beauty of the river wotuld be in a' great meafure loft, and the iprincipal parts iof the adjacentit grounds: foured, and rendered almoit ufelelfs, from the long continuance of the back-water, itwhich by reafoh of the high banks along ithe riverglcould not efeape, or fall back into the bed of the river, when the water fell,

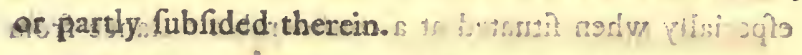

- The firft point moft neceffary to confider was, how to difpofe of thofe banks, or lips, to the beft advantage, which almoft accompanied-the tiver through the de-

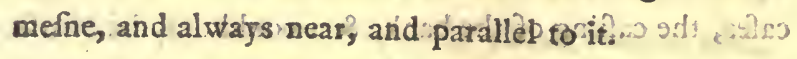

Where the ground Happened to lie hollow, or low behind the lip, thete was no difficulty in difpofing of the fruff to advantage, as it was either wheeled or carted back, fo as to make the general fall to the river as abrupt as the nature of the place could admit of, in order to prevent the like accumulation of fand for the time to come. But, previous to the taking away thofe 
banks, the good foil or furface of the parts, on which they were intended to be laid, was taken off, and referved for a top-dreffing for the whole, when brought to the intended mape. This precaution was the more neceffary; fince thofe banks were principally compofed of barren fands, and of themfelves not capable of fupporting any agreeable verdure.

-1s In molt cafes the grounds lie rety flat behind the banks to a confiderable extent, what in thefe parts are termed holmy lands. Thofe flats ior holmes being naturally extremely fertile; the covering of them 'with the barren banks was of courfe given up; therefore the barren ftuff was in general calt into the river, or buried in fome adjacent pits or hollows.

:2. In order to render the foil wholefome, where ${ }^{2}$ the flats, and, in fome places, concaves prevailed; and efpecially when fituated at a confiderable diftance fróm the river, recourfe was had to another expedient, befides that of cutring away the banks, and noping them down to the water at low-water-mark; fince, in flich cafes, the cafting of the bank, \&c. could only be of ufe, fo far as that operation could be applied, to caufe the water to run off freely when the bed of the river fub: fided, and alfo to prevent the accumulation of the fand. jo future. 


\section{APPENDIX:}

The method is fimply thus.

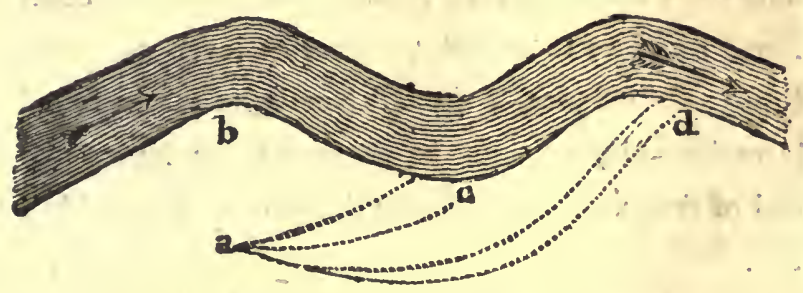

- $a$, The loweft point of the holm, at a confiderable diftance from the river, fuppofe a hundred yards. This point may be lower than the point $b$, in the river at low-water-mark; but it may be confiderably higher than the point $c$, a confiderable way down the river, fuppofe three feet. Now, if the ground be excavated from $c$, to $a$, making the excavation mallower and fhallower as you approach $a$, where it hould rife out to the furface, it is plain, that the whole of that quarter will be laid dry when the river falls, or arrives at low-water-mark. In finking about three feet at $c$, the breadth of the excavation is about, twelve feet, and brought to a point at $a$. The fection of the part excavated will appear thus, which has no bad effeet when

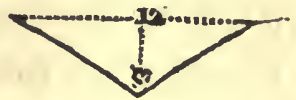
fwarded over, nor can it be perceived without a clofe infpection. Several of the foregoing contrivances have been introduced at $\mathrm{Ranh}$, none of which has been ever found to fail. 
The back, or ftagnated water, is the beft guide to point out the courfe for introducing the excavations or difcharges into the river; it has, however, been often found neceffary to attend to accurate levels along the banks : for inftance, if the fall from $b$, to $c$, was found inconfiderable, it might be encreafed, by letting the cnd of the excavation fall into the river at $d$, inftead of at $c$.

It is plain that, when the water fubfides in the river, the waters of the flats and plains will fall into the excavations, and from thence be immediately carried into the river, and all behind laid perfectly dry in a few. hours, which has been invariably the cafe here for many years back.

- This work is always performed in the fpring feafon, in order that the furface may be completely fwarded over, before the autumnal rains fet in. With refpect to fwarding, or creating a new furface for thofe excavations, the beft mode by far is, to make ufe of the old furface; but, inftead of laying it on in regular uniform.fods, it Thould be chopped into a number of fmall pieces, and firmly beaten together by the back of the fpade. Experience has, on many occafions here of making new furfaces, fhewn the fuperiority of this practice orer all others, in point of fability, and firm texture; but it fhould be attended to early in the feafon, otherwife it cannot fucceed; befides, the old furface goes further when thus treated. The excavations, 
above alluded to, have in general been fwarded from the fpace or old furface cut away, where the excavation was to be introduced; though the area of the latter muft, of courfe, be confiderably the greateft.

It is well underftood in this neighbourhood, that, fince the banks of the river have been difpofed of, and the excavations, \&x. perfected, little or no injury has been furtained, and that the good effects refulting from it have been experienced fo far up the river as the town of Omagh; but this requires no demonftration; the impediments, which were formerly the caufe of the contraction of the water, being removed, the lands up the river, for a confiderable way, muft, of courfe; benefit thereby, fince the water, in its progrefs thro' the demefne, meets no oppofition.

Had the banks of the river, from the ftone-bridge; which terminates the river on the north, to Newtown-ftewart, been low, no doubt but the adjacent lands muft have fuffered by the fudden influx, which was occafioned by removing all impediments through the demefne; but they are quite the reverfe; thcy are bold and permanent, and bid defiance to any encroachments or impreffions the water can poffibly make.

The foregoing part of this work colt upwards of one thoufand pounds; it was almoft all performed by tafk or piece-work, of which regular accounts have been kept, as well as of all other fpecies of tak-work, 
fince the year 1790 , prior to which the various kinds of piece-works have not been brought under regulat or diftinct heads, though vaft fums had been expended; but the real fpirit of working by takk did not commence till about the above period. To all parties concerned, every day's experience fully demonftrates the great advantages talk-work has over common day's labour, which Mall be fully explained in another place. But to return.

Wheeling or carting from forty to fixty yards diftance; the price by the folid yard is generally from $2 d$. to $3 d$., and fo on in proportion. When the ftuff was caft into the river, or immediately difpofed of upon the fpot, the price was ufually fixed by the running perch, commonly from 5 s. to Ios. according to the dimenfions of the bank or lip, which in many parts exceeds fix feet in height above the plane or general level, the bafe being from fifteen to thirty fect; tapering to a point; but the part of the bank next the river is generally the molt abrupt.

But the great expence did not end here. Vaft gullies, and breaches in the edges of the river, remained to be fecured, many of which were of fuch magnitude, as to require a very ftrong barrier.

Large creels or kimes, made of oak and hazel, were generally made choice of; thefe were commonly fix feet long, four feet wide, and from three to five feet deep, according to circumftances; and in many parts 
two creels, perhaps five feet deep each, were let down by a kind of lever, one placed over the other, both being filled with ftones after being fecurely fixed at front by a ftrong row of oaken piles, placed within about a foot of each other; the length of the piles generally from fix to twelve feet, and fometimes more, according to the depth of the water. The piles are bound together by ftrong hazel wattles. The bark was previouly ftripped off the piles, not altogether on account of the profit to be made of it, but upon a prefumption that they would laft longer, which indeed proves the conjecture to be well founded.

The work is completed by floping the bank down to the piles, taking great precaution in introducing tough fods, or fuch as beft agree with water, and that are leaft fubject to be wafted by the frequent agitation of the waves, at or near low-water-mark; a circumfance, which cannot be too well attended to, being the precife medium, at which the banks of rivers and lakes fuffer mont; as banks, when fecurely formed, and well nloped, feldom or ever fuffer by flood-zuater. The common fedge, or reed-grafs, is admirably well calculated to fecure the banks; on many parts of the banks of the Mourne river (which is the general name) it grows fpontaneouny; and, where it fully eftablithes itfelf, it generally fuperfedes all other precautions in point of fecurity. Here great induftry is ufed to introduce the reed-grafs, which has hitherto fucceeded; it is cut into 
large fods in fome remote parts of the demefne, or wherever it can be procured, and placed behind the piles; and in many infances it is found to fucceed without any further affiftance; but this muft be underftood only of thofe parts, where the water has no power of making much impreffion. Many other plants are well adapted to fecure againft the incurfions of water, fuch as the flote-grafs, and the creeping bent-grafs. Rumes and fprits make a frong and permanent fecurity to banks, but in a fine fcene they frould not be introduced, but, upon the other hand, fhould be moft induftrioully extirpated. Fortunately the banks of the beautiful river, which paffes through this demefne, arc not much encumbered with any difagreeable plants of the native growth. Where the banks are principally compofed of barren fand, the largef fpecies of the native colt's-foot has eftablifhed itfelf, which is a moft fortunate circumftance, as the roots are fo extremely well calculated to bind the fand; and the great fize of the leaves effectually conceals it in the fummer feafon.

: It is fcarcely neceffary in this place to remark, that the difpofing of the banks, and the creeling, piling, \&c. went on at one time, fince the fecuring of the verges in a great meafure depended upon that mode; for, in moft cafes, had the banks or lips been firft taken away; or otherwife difpofed of, in one fummer feafon, and the piling, Sc. introduced the fummer. fcafon following, 
the rerges of the river would fuffer confiderably in the intervening winter. At the commencement of thofe operations, part of the work fuffered materially by not ${ }^{\circ}$ attending to the above precautions; this difafter, however, ferved one good end, namely, not to truft in future to the mercy of floods.

It is plain, that this bufinefs altogether muft be attended with great expence. The making of the watercreels, at Is. each, is equal to about $3^{s .} 6 d$. a perch for creeling only, befides the expence of cutting and drawing the ftuff. The number of piles, neceffary to fecure a perch in length, would fell for 8 s. for cabin-building, \&c.; fo that, confidering the expence of drawing ftones, fetting the creels and piles, Moping and fodding the banks, \&rc., the whole cannot be rated at lefs than one guinea a running perch, befides the original coft of difpofing of the banks. Setting the creels, driving the piles, and noping and fodding the verges, are always performed by day's work, as it would be found difficult to fix a price by piece-work; and befides, too much care cannot be taken in thofe operations, fo that, even if they could be accurately fettled by tafk-work, it fhould by all means be avoided, 'as the leaft miftake or hurry might be productive of a great deal of mifchief; and there is never any temptation of doing any work, when performed by day-labour, in a lovenly or bad manner. Yet, notwithftanding, tafk or piece-work Should always be preferred to day-labour, where there 
is any poffibility of fettling the price with accuracy, or "that there be no hazard in performing the work in a Rovenly manner, without being eafily detected. It requires a long and intimate acquaintance with country works, to be able accurately to inveftigate the various prices and rates of tak-work, which muft in a great meafure depend upori the rates of common day-labour, being the beft guide to go by.

So much for the weighty works of the banks of the river, which required to be managed, as above ftated, in a moft permanent manner. Thofe parts, which were molt likely to fuffer, were always firft attended to.

But as to fuch parts as were not fuffering materially, תighter materials were found fufficient to fecure them. Spruce and Scotch firs, from fix to twelve feet high, were found to anfwer this purpofe extremely well. 'Thefe were cut down with their entire branches, and packed together, as clofe as they could be placed, in the parts of the banks difpofed to yicld only nightly, or where ftrand-like appearances were about to take place. In fuch cafes there is nothing more neceffary, than to arreft the fands and other materials, which may be brought down the river by floods.

The Atrand or naked parts being judiciouny covered with bruh-wood of any fort (full of foliage, for the clofer the better), and fecurely confined, a new furface is foon created. A few floods are fufficient to depofit 
plenty of fand, \&xc. to form the new-made foil; after which there is no further trouble than that of planting plenty of fedge or reed-grafs, and other aquatic plants, which are foon formed into a firm agreeable fward.

To enumerate the various expedients made ufe of in common cafes, or where great exertions were not found neceffary to fecure the banks, would be endiefs. The fimple circumftance of finding fand, and other productions after floods, detained on the banks by fome night caufe, fuch as tufts of broom or furze; or, perhaps, rank grafs or weeds, was the firft indication, no doubt, to adopt fimple means, which moft commonly fucceed beft.

The great fecret in this bufinefs is, to contrive means to collect the fand, \&c. by the foliage of the bruih-wood, and, when fo collected, to prevent it from efcaping into the river at the time of the ebbing or return of the water into its ufual channel.

Since fo much depends upon the brukh-wood and branches being as rich in foliage as poffible, the fummer months anfwer belt for all works of this nature; "not only on this account, but becaufe at that feafon labourers make greater progrefs than at any other feafon, fince fometimes they muft get into the water.

The common mode is to make a light hedge of fake and rice, along the edge of the water at low-watermark; it is of no confequence of what fpecies of wood the ftakes are compofed, but the brufh-swood, which 
forms the rice, or that part-woven through the ftakes, fhould be very clofe; fir-branches of any fort, broom, furze, or juniper, are very well calculated for this purpofe. About eighteen inches is the ufual height of this fimple barrier above the furface of the water at lowwater-mark, as its ufe is only temporary to detain the fand, becaufe the reed-grafs, and other water-plants placed behind it, foon penetrate through it, and join the water in the courfe of one or twq feafons, and orerwhelm the frake and rice altogether.

The bare parts of the bank, behind the frake and rice hedge, are in general filled up with young trees of fpruce and Scotch firs (the former is the bent) of different lengths; thefe are cut down, for the purpofe of thinning the young plantations, with their branches quite entire, and placed in the breaches of the banks, or where the water is difpofed to make any impreffions, as clofe as they can be packed together, inclining the tops fomewhat in the direction of the water; thefe are laid down, and fecured with any rough pieces of wood, which are in general about the thicknefs of the fmall part of a man's leg. In order to fecure thefe pieces firmly, hooked ftakes are driven a confiderable way into the bank, fo that the hooked part of the fake may come in contact with the leger or rough piece, which binds down the brußh-wood. In fome cafes, where the breaches are not confiderable, fods and nopes are ufed to fecure the bruh-wood from being carried 
carried away by the floods; but this takes place only where brufh-wood of any fort may be thrown in indifcriminately, and where the action of the water is not fevere.

Whatever means may be ufed in fecuring the brufhwood, they are of no further ufe after two or three confiderable floods have taken place, as the quantity of fand, \&c., collected by that time, is moft commonly fufficient to do the bufinefs for ever after.

Roots of aquatic plants are always fcattered plentifully on the bare parts, before the bru@-wood is laid on, which foon vegetate, and make their way upwards through the brufh-wood, and affift in a furprifing manner to arreft the fand, \& c. The common couch-grafs, fo deftructive to fome cultivated land, is found to anfwer extremely well, when frewed on the bare parts, before the brufh-wood be laid on; many other plants, not merely aquatic, will anfwer the fame purpofe.

Several large pits, and aukward fpots, have been filled from time to time, in the bolmy grounds in the neighbourhood of the river, and made completely even and uniform with the circumjacent land, by fimply throwing in bruin-wood of any fort, covered with a few fods and ftones, to prevent it from rifing, or being . carried off by the floods.

At Rah fuch places are confidered as receptacles; for the purpofe of concealing the vaft quantities of brunt-wood, perpetually produced from the thinning 
of the young plantations; and, though large quantities are annually difpofed of otherwife, yet a great deal of the moft inferior fort remains for this purpofe. Whenever the brum-wood becomes a nuifance, it is difpofed of, as above ftated; but the months of Auguft and September are thofe preferred for filling pits or hollow parts, on account of the autumnal floods prevailing at, or fhortly after, thofe times.

SEcr. 8. An Account of $T_{a f k}$, or Piece-work, together with a comparifon between it and common Day Labour, with fome remarks on labouring Tools and Implements.

UNDER the head, Wages, \&ec., fome remarks have been already made; but I could find nothing like a regular ftandard throughout the county, by which any material knowledge might be obtained, except at Rah, which here I hall briefly ftate, and it may be depended on, as an accurate report.

At $\mathrm{Ra}$, where common labọur rates at $8 d$. a day the year round, a hilling is confidered a fair allowance to make for takk-work upon the average of the whole year. In the winter feafon a labourer generally makes as much by day's work as by tafk-work; but in fummer there is no comparifon at a!l, that feafon bsing fo farourable to the latter. But with 
tan-work the labourers are always beft pleafed, and it is certainly molt in favour of all concerned, fo far as the nature of the work will bear it to be carried on in that manner.

Ditches of feven by five, that is, feven feet wide from the face of the bank to the verge of the gripe, and five feet deep perpendicularly, at from $2 s$. to $2 s .8 d$. the running perch of feven yards; ditches of fix by four, from is. $6 d$. to 2s.; and fo on in proportion. The dreffing of the backs, and fodding the tops of the banks, are included in the prices of all ditches., The above dimenfions, with refpect to the breadth, are clear of the fcarcement or off-fet, which is commonly from fix to twelve inches, according to the fituation, or the nature of the foil.

Drains, in clay foils, from eighteen inches to two feet deep, at from $2 d$. to $3 d$. a perch; one halfpenny a perch is' ufually allowed for fcattering the ftuff on the furface, when they are intended to lie open for fome time. When fprings are in queftion, the prices, of courfe, muft vary; for a given depth, fuppofe four feet, $6 d$. a perch is ufually allowed, and, if further finking be neceffary, in order to intercept the fprings, a fecond price is made; for an additional foot, after finking four feet, $2 \frac{1}{2} d$. is added, $3 d$. for the next foot, and fo on in proportion. When the depth neceffary to fink, in order to intercept the water, cannot be afcertained at the commencement of the work, there is no reftraint 
reftraint laid upon the labourer, with refpect to the breadth of the drain, fince it is fufficiently underftood, that labourers can make more progrefs when allowed fulficient room to work, than when confined in a narrow drain; befides, fuch drains cannot with propriety be. finithed off the firlt feafon. Filling in ftones, in drains of all defcriptions, is always done by day-work, a wo:k which thould never be trufted to tafkers on any account, as one ftone; aukwardly placed; might deftroy the whole drain.' This kind of work, too, is always performed by fteady labourers. Bog-drains are generally at half the price of thofe made on firm land.

- Trencbing.-Double trenching, generally practifed for nurfery; at from $8 d$. to 15. a fquare perch.* This kind of trenching, when performed in lea-land, is done by paring the furface about two or three inches deep, and turning the fward downwards, over which the remainder of the good foil is turned. The whole depth is generally from eight inches to one foot for feminary, but, when intended for nurfery; the depth is generally more, and, in hallow foils; a few inches of the fubftratum are turned up. The ufual mode, howcver, of preparing the foil for nurfery is, by fowing potatoes 'twice, which is found by far the beft eco-

nomy.

* Though the Cunningham or Scotch meafure is adopted in many parts of the county, and even in the neighbourhood of Rafh, yct, when I fpeak of a fquare perch, I always mean the plantation one, or forty-nine fquare yards. 
Domy. Trenching is always performed before the frofts fet in, and raifed in round ridges of about three feet. By adopting this mode, the foi. receives the full benefit of the frofts, and befides, חovenly or light performances are, more eafily detected, than when the ground is trenched in the flat or level manner. Single trenching, for the purpofe of levelling and fmoothing the furface, in laying down grounds where the plough cannot act, at from $3 d$. to $6 d$. a fquare perch.

Removing earth by the folid yard, or a cube equal to twenty-feven folid feet. This kind of work is al ways meafured, before the earth be removed, and not after., Wheeling, from twenty to fixty. yards diftance, from 2 d. to 3 d. a yard.

A great deal of -boggy land has been covered or clayed here from time to time. A navigation wheel. barrow, well filled, will cover a fquare yard to the depth of two inches. A folid yard, in this cafe, is rated at eighteen barrows, at nine lide:car-loads, and at three wheel-car-loads. The price by the perch, or by the acre, /s always regulated by the depth of ftuff laid on the bog, which here is generally four inches, and has amounted to from, $8 \%$. to $10 \%$ an acre, according to the diftance the fuff was wheeled or carted.

It requires a great deal of addrefs and accuracy to prevent fraud in carrying on fuch works. The moft certain mode is, firft of all to fmooth and level the bog, to be covered, effectually, a year or two previous to 
the covering; indeed the longer the better, in order to give the bog time to fubfide, and to acquire a vegetable furface of fome fort, to prevent the hard materials from finking. When the bog is brought to the wishedfor thape for laying on the clay or gravel (the latter is. certainly the beft, and the coarfer the better), a num-! ber of ftakes are put down in parallel lines, at about ten fect apart, ot nearer (for accuracy, the clofer the better), leaving only four inches of them to appear above the furface; the covering ftuff is then laid on, to be equal to the tops of the ftakes. It is eafy to ex-' amine the fakes after the foil is laid on, where any fufpicion inay arife; but, as it is fo eafily detected; there is feldom any advantage taken by the tankers; and the more fo, as a penaity is always inflicted where there is the leaft appearance of fraud. I Mould have remarked before, that the white meadow grafs is fown in large quantitics on the bogs, after being levelled, and previous to the laying on of the clay or gravel, which feldom fails to produce a permanent and ftrong furface, capable of preventing the hard materials from finking.

1 'To cnumerate the different works, carried on by tafk throughout the demefne of Ran and its environs; would fwell this article far beyond my prefent plán; I fhall, therefore, only give a general hint how to afcertain a reafonable price. 
It has been already obferved, that the prices of tafkwork muft be governed by thofe of comman dayJabour. Old eftablifhed rules, fuch as the prices of ditches, drains, \&c. are eafily afcertained from long habit and experience; but it is not eafy to determine the value, which thould be fixed for many other works, which may occur in an extenfive improvement, and it requires both ingenuity and addrefs to be able to deal fairly with labourers, who are in general very keen with refpect to the making of bargains favourable to their own, views.

In order to fettle any doubts, which may arife with refpect to the fair value to be given for any job of talkwork, which at firft view may be found difficult to determine, the labourer fhould be kept ignorant of the mode of payment; that is, whether by day-labour, or by tank-work. A few days, or perhaps a few hours, may determine what may be thought a reafonable price by tafk-work. It is needlefs to remark here, how very neceffary it is to have a trufty confidential perfon to fuperintend any bufinefs of this nature, and efpecially at the commencement of it. If labourers are kept ignorant, during the whole time of executing any job of work, of the manner in which they are to be paid, they will, of courfe, work diligently, becaufe, if the payment fhould be made in confideration of takk-work, without working diligently they would in the end find themfelves much difappointed. It is, however, by far 
the beft mode for all concerned, to determine the price as foon as may be convenient, by which the labourer will undertake his work at once with fpirit and alacrity, and the employer will be certain of having his work done expeditiouny.

I have often afcertained the object of my wilhes, by placing a fteady labourer, for a few hours only, at a job of labouring work, the fair price of which at firft view appeared doubtful. A perfon may take out his watch after he turns his back to a labourer, walk away, and return again at a certain time, and thus be able to calculate the fair price, that fhould be given.

To enable tafk-labourers to carry on different kinds of work with eafe and facility, fomething better than the common fpade and Shovel, peculiar to the county, is allowed to them. Ten pounds a year go a great way in purchafing drain-tools, navigation-\{hovels, pickaxes, calting-fcoops, \&c. Without allowing labourers implements properly calculated for different kinds of tak-work, complete execution cannot be expected.

Complete implements for labourers, ufually employed in tafk-work, are always in readinefs at $\mathrm{Ra} h$, to be given out to them occafionally; and, in order to prevent thofe tools from bcing loft, or otherwife difpofed of, fevere fines are inflicted, gencrally double the value of the article; becaufe, if only the value of it was charged, the labourer would fuffer nothing by felling it at the fame price. 
In giving out implements to tafkers, the firft point is, to charge them double value on the debt fide of their account, which charge is taken off at the conclufion of the work, when the articles are delivered up unbroken, or without being damaged, otherwife, than common wear, for which they are never charged; but. if they break an article during the time they have it in. charge, they muft repair it at their own expence.

Sect. 9. Manner of training up Boys, fo as to become ufeful, Aeady Labourers, with a number of ways to "employ them to the beft advantage the year round. Allo; Several Modes, by wobich old Men, when partly paft their labour, may be applied to advantage to themselves and their Employers.

A CONSIDERation of the greatent importance is, that of raifing a race of ufeful perfons, at the commencement of every ufeful and extenfive improvement. At Ran this precaution was early attended to, which fince has been productive of many folid advantages, both to the proprietor, and the individuals themfelves.

Since, in all great undertakings, feminary and nurfery thould always precede planting at large, boys will be found very ufeful from the commencement; and, by the time the firft courfe of feminary and nurfery may 
be over (probably in five or fix years), they will, of courfe, become very expert, and fit to engage in the general planting; and, as this bufinefs encreafes, others, of courfe, will be coming forward. After ferving folong a period in the infant part of the im. provement; they will be found more ufeful than grown-up perfons, picked up indifcriminately through. the couatry at large. - At leaft boys, thus trained, the writer knows, from long experience, to have uniformly turned out the beft planters and groundworkers, having, by early habits, acquired a degree of fmartnefs and activity, which they feldom depart from when grown up, or even in an advanced ftage of life.

Perhaps in this place it may not be amifs to Shew how to fecure boys, fo as to make them attend regularly to the works of a demefne, till they may become of more general ufe to themfelves and to their employers. Unlefs fome effectual method be taken, they will always wilh to wander upon every trifling occafion, or any advantage they think may turn out in their farour.

The method followed at Rafh I thall briefly ftate.

Boys, from ten to twelve years of age, are ufually taken in from time to time. "They remain two years at $4 \pi .2$ day; the third year they receive $5 d$; the. fourth, and fometimes not until the fifth year, the wages are advanced to $6 \%$; and, in the courfe of $a$ year or two after, they are raifed to man's wages, or 8d. a day.

When 
When a lad is found to have an extraordinary hare of ability and fmartnefs, one year of his time is given up, or, in other words, he is put on man's wages a year before the ufual time.

I am apt to believe, that a fyftem, which has been found to be of fuch general ufe by the ever to be regretted the late Lord Mountjoy, will not eafily be forgotten by his fucceffor; nor do I in the leaft defpair of finding it become general throughout our extenfive improvements in the kingdom at large.

It is eafy to conceive, that the certainty of having the wages raifed, at fixed periods, induces the boys to ferve out their refpective times. If, however, it hould to happen, that a lad, through tricks, or other motives, fuch as going to fervice to a farmer, or the like, and if, after fome time, he hould change his mind, and with to return again to join his work, in this cafe he muft begin again, as if he never had been entered at all, though the tranfgreffion fhould be committed the laft year previous to his being entitled to man's wages; thus few defertions ever take place.

Upon the other hand, if any perfon, either young or old, at $R a / h$, hould meet with any accident, when actually engaged in any of the works, his time is always allowed, as if he had been at : work. $R a / b$ is feldom without a great number of invalids; the great number of working people, together with their intrepidity, fully accounts for this circumftance.

Here 
Here is another great inducement held out; namely, fome of the boys, through merit, deferve higher wages. than others. Dexterity in pruning, grafting, inoculating, making cuttings and layers, clipping hedges, with many other nice works, which naturally occur in fuch an extenfive demefne, are motives to give encouragement to the moft deferving. The afpiring lads do, therefore, avail themfelves of fuch opportunities as lie open to them. The moft active will, of courfe, be firft promoted to ferve gentlemen as planters, \&c.; the next clafs ftep into the place of the firnt, and the third into that of the fecond, and fo on, ftep by ftep, to the lowent boy. Thus, like the army, there is always a feries of promotions after the fir $f$ takes place.

Here it may not be amifs to point out the moft likely ways of employing the boys to advantage the year round, fince the cafe is not the fame with them as with grown-up labourers, who may be fet to many kinds of ftock-jobs in all weathers; whereas with young lads there mult be works laid out fuited to their ftrength and conftitution, particularly in the winter months; otherwife they will not be found ufeful.

I Shall now ftate the principal works fuited to boys, and particularly fuch as occur at $\mathrm{Ra} h$, and mall begin with the fpring quarter, at which feafon there never can be a lofs for ufeful employment for them.

The moft aukward of the planting labourers are generally employed in making holes for trees; the moft 
expert of the boys are commonly engaged in planting them, for which purpofe they are better calculated than labourers in general are, efpecially where the foil is loofe, and the plants finall. The weakeft of the boys anfwer to carry the plants about from place to place, and alfo to drefs and fettle the ground after the planters, to pick off ftones, and to do other ufeful works. This clafs alfo, with an intelligent perfon over them as a captain, are extremely well calculated for bringing up the rere of the planting, by fowing broom, furze, and laburnum-feeds for Mhelter.

In like manner they may be employed in planting out nurferies. Indeed in that fpecies of planting there are fo many ways of performing it, that the weakeft of them may be employed to as ufeful purpofes as the ftrongeft:

When much planting is to be performed in one feafon, which here is commonly the cafe, fmall parties are formed, with an intelligent perfon at the head of each, and efpecially when the feafon's planting lies fcattered and detached; but, when the work lies connected and compact, the reverfe is the general practice, in order to keep all as much as poffible under the eye of the head planter; a fyftem which, in all cafes, let the work be what it may, hould be attended to as much as poffible.

So much for the fpring, and now for the fummer quarter, which naturally points out the neceffary works.

I believe 
I belicre I need not point out, that weeding and cleaning the plantations, nurferies, feminaries, ditches, \&c. muft form the moft effential parts of the fummer works. For thefe works boys àre extremely well calculated, fince a boy, in fuch cafes, may be found as ufeful as a man, and frequently more fo.

The regulations, with refpect to tools and implements, may probably, with fome propriety, be introduced here, though fome hints have already been given upon that head.

Each boy is furnithed with a fcuffler or purhinghoe, a weeding-knife, \&c., which are numbered and charged to their refpective accounts; otherwife thofe articles could never be kept together with any degree of regularity. At the latter end of the feafon, when the works of the nurferies, \&c. are over, the implements are put up, and the charge taken off the boys till the enfuing feafon, when it commences again, and fo on. But this fyrtem is not confined to the planters alone; it is general in all other departments in the demefne.

As the care and management of tools and implements in an extenfive demefne is a matter of great confequence, and one which the mafter of works Sould be particularly attentive to, I hall throw out a few obfervations by way of advice.

The firft thing to confider is, to take an exact inventory of all the tools and implements in the place, 
ranging every article under its proper head; the charge of which hould be given to one perfon only, who Mould be of a Marp retentive turn. Every fet of articles Thould be numbered; for example, wheel-barrows No. 1, 2, 3, \&c., and fo on with all other articles. This will enable the perfon, who is in charge, to keep a regular account. Next, let that perfon charge the articles to thofe, who may occupy them; not the real value, but the double of it, or, at leaft, confiderably above the value. This charge fhould remain in force, till the articles are returned, whether broken or not. Wear and tear upon all articles cannot be avoided, nor is it fair to charge fuch to the labourer's account; in fome inftances, however, according to contract, it is common and fair that tafkers hould return articles in 'the fame order, in which they got them.

There fhould be, of all kinds of tools and implements about a demefne or place, fome fpare ones in readinefs, in order to fupply the place of fuch as may chance to be loft or broken. Such need not be numbered, becaufe they only ftand as fubftitutes, in cafe a repair only be neceffary for the abfent article; but, if that article be lof, the fubftitute fhould be numbered agreeably to the number of the former. Thus regularity will be always kept up, and labourers and tafkers will meet with no interruption in the progrefs of their works. 
A fteady perfon, charged with the above kind of arrangement, is one of the molt ufeful men that can be employed in a demefue, or where much works are carrying on.

I believe I need not point out the great advantage there is in keeping all articles clean and dry, when laid up, or not in ufe. The oftener they are called in, and newly arranged, the better, as thereby there will be fewer miftakes and loftes.

The new implements, \&c. Mould always - be kept feparate from the old ones, in diftinet columns.

It is now full time to return, "in order to point out the works of the autumn quarter.

The beginning of this quarter is ufually taken up in putting out evergreen fhrubs, fuch as laurel, Portugal laurel, lauruftinus, \&c., and, alfo, in planting cuttings of the fame, and in many other articles, fuch as cleaning hedges for the laft time, when it fo happens that two weedings are neceffary in one feafon.

But the greateft point of all to attend to, fhould be that of fecuring young trees put out the laft fpring, particularly of the pine kind. This is the time to give the finihing ftroke to every plant encumbered with grafs and wceds; becaufe, if fuch fpontaneous growth mould remain till too late in the feafon, the rains and damps, which ufually take place at that time, rot the vegetable matter about the tender branches of the young plants, to their great detriment, and very often 
to their total deftruction. By not paying due attention to this particular, more plants fuffer than by all other accidents put together, at leaft in moift fituations. Indeed this precaution is perhaps more neceffary in Ireland, than in England or Scotland.

In fuch cafes, the boys are furnifhed with fmall hooks or fickles, which are alfo numbered, and charged to them; and, upon fuch occafions, a boy is found of more ufe than a man.

In the latter part of the quarter, boys are employed to great advantage, in trenching ground, and digging nurferies. In thefe works the weakef of them are placed at the lighteft and eafieft parts. In the former, marking out the lines for the trenchers, and Movelling up the crumbling mould from the trenches, are works fuitable to their ftrength. In the latter, cleaning the rows of plants, before the diggers, is a kind of bufinefs, to which boys are well calculated. Thus, by a judicious diftribution of the whole, no part can be ufelefsly employed.

Collecting various kinds of feeds is peculiarly fuited to boys, as their dexterity in climbing gives them the preference to men. Upon thofe occafions they are generally tajked; that is, each of them muft produce a certain meafure every evening, after the day's gathering, and continue the fame allowance fo long as the feeds continue plenty. But the ufual way is, to pay fo 
much a meafure, according to the fpecies of feed; and fome articles are paid for by weight, to prevent the impofition of mixing leares and falks with the pure feeds. When the feeds are weighed, the boy is always a lofer by collecting leaves and ftalks, fince a meafure of pare feeds will always weigh better than when adulterated. The meafure of pure feeds, however, with refpect to weight, is afcertained at the beginning of the feafon, which prevents any difputes that may arife. Sixteen gallons is the ufual meafure. In haws, when gathered clean, fuch meafure is commonly equal to eight ftone and a half; afh and fycamore keys about fix ftone; and fo on.

I have now accounted for three quarters of the year fpent in ufeful works, to which I might add many more, but thall proceed to the laft or winter quarter; in which, though boys may not be fo ufefully employed as at other feafons, yet, notwithftanding, many works may be ftruck out for them to ufeful purpofes. In the beginning of the quarter, haws, holly-berries, fpindletree, \&c. are ufually collected. Joined with labourers, boys are ufefully employed in turning and forming compofts; they break the clods, \&ce. and blend the parts together. In funhine weather they may be employed in collecting ftones off of lawns, and newly laid down grounds.

Boys are found extremely ufeful in collecting leaves in the woods and plantations. Even though the leaves 
Thould be applied only to affirt in making manure for potatoes, they, notwithftanding, pay amply for the trouble attending them. Indeed there are few works boys can be better employed at on a cold winter's day, than collecting of leaves.

Boys are employed to a very good purpofe, in bringing the prunings and loppings of trees to convenient places for cars to get at them conveniently.

Thefe are but few among the many works, that this little army are ufefully employed in; the nature of the place, and other circumftances, always point out the moft ufeful works to engage in.

By good management, there can be no doubt but boys may always be found ufeful; but, even if this hould not be exactly the cafe in winter, it is good policy to retain them under half-pay, or for fome trifle, till the bufy feafon, in order that they may not be altogether a burden to their parents, and that they may be at hand; and in readinefș, when there is a preffing call, and not fuffered to wander through the country, as, probably, it might not be eafy to collect them again when moft wanted.

There is fcarcely a labourer now (1802) at Rafh, in any department, who was not formerly employed when a boy, and from one ftage of pay advanced to another, till he arrived to man's wages; no wonder, therefore, that it Should have, within the laft twenty years (ending 1802), produced a great number of ufeful hands, 
hands, probably more fo than any other part of the United kingdom.' Indeed many of them are planters, of no fmall confequence, to noblemen and gentlemen throughout the kingdom.

Some of the labourers, found at $R_{a} h$ at the commencement of the improvements, are at this time old men.

Care has been taken, from time to time, to provide fuch labourers with employments in the demefue, fuitable to their ftrength and circumftances. The following may ferve to thew, how far this falutary object has been carried into execution, and alfo, what the late Lord Mountjoy's further intentions were, which, there is every reafon to hope, will be perfected by his fon, the prefent Lord Mountjoy.

Obfervations avith respect to old Men and their familiesthe manner of employing them-with remarks on an b.opital intended to be erected for their reception.

The prefent practice is, when a labourer drops off, fo as not to be able to fupport his ufual rank or ftation among his fellow labourers, to place him at fome light work, fuitable to his ftrength and capacity. In general a yearly allowance is fixed, moft commonly five or fix pounds, with a cabin, and other privileges, fuch as 
potatoe-land and turf, and, if he has a wife, a fpot for flax, generally half a rood of land. There are fome inftances, however, of making it a daily allowance inftead of a yearly one, the better to prevent impofition, which, indeed, upon thofe and many other occafions, cannot be too much guarded againft, fince there is nothing more common, with thofe invalids, than to reprefent their health to be much worfe than is really the cafe. In this cafe a charge is made of the privileges, and he gets credit for the time he works, either by the day, by the job, or piece-work, as the cafe may be.

When the invalid dies, if he hould leave a widow, which is moft commonly the cafe, the is taken care of alfo, by allowing her fome portion of what her hufband enjoyed, indecd freyuently the whole of it, and efpecially if the fhould be encumbered with any charge, which often happens to be the cafe.

The following are only a few, among the various jobs invalids are generally employed at throughout Lord Mountjoy's improvements.

Lodge-keepers.

Preparing walks and drives, where light repairs only are neceffary;-conducting water from them after fudden rains, \&cc.

Making up billet-wood, \&c. for fuel.

Cutting and preparing fcollops for thatching.

Sweeping 
Sweeping yards, \&c.

Attending cattle, poultry, pigs, \&c.

Wceding nurferies, ditches, \&.c.

Collecting leaves for manure.

Picking and preparing potatoes for feed, and for food for cattle, \&c.

Making various kinds of creels and bankets.

Drawing ftraw for thatching.

Turning and preparing dung and compott heaps.

Spreading dung for potatoes, \&c. \&c.

Old men are of great ufe on many occafions; indeed I have known many of them to be more fo than perfons in the meridian of life. The only point to attend to is, to fet them to works fuitable to their ftrength and conftitution, and they will always be found ufeful to themfelyee, and to their cuployers and patrons.

Old men in general are fond of company. If two of them are placed together, they look upon themfelves to be well treated. They fpend the day in talking over paft times, aird of their great feats when young men; yet all this will not prevent them from going on with their works in a low but fure manner.

In fetting old men to work, many jobs fhould not be laid out, or propofed to them at one time, as in general they are forgetful. The beft way to make the mott of them is, to praife their performances, and find as little fault as polfible, fince they are in general te- 
nacious of their own ways, and cannot bear the fpur, which, on account of their age and infirmities, hould not be often applied.

'The late Lord Mountjoy had no object more at heart, than that of eftablifhing an hofpital upon a large fcale for the accommodation of invalids, not only thofe of the demerne, but fuch as were found proper objects throughout his extenfive eftates in the counties of Tyrone and Donegal. His intention was to have it amply endowed, and divided into three principal heads or clalles, namely;

I. For invalids, with their wives.

2. For invalids, without wives.

3. For widows of invalids, and other diftrefted objects.

Gardens to be annexed to the different deprartments, and to be cultivated, for the ufe of the whole, by fuch of the invalids as were found able to work.

Flax and wool to be ferved out to a certain proportion, to employ the women in fpinning and knitting: with an annual allowance of clothing and fuel for the whole.

In this place I am happy to have it in my power to fay, that his prefent Lordhip appears fully determined. to put this laudable plan into execution, with many others, which his memorable father had fuggefted. 


$$
c^{3^{3^{p^{2}}}}
$$





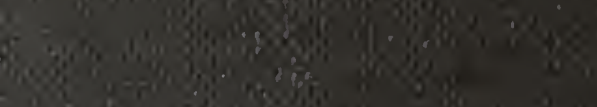

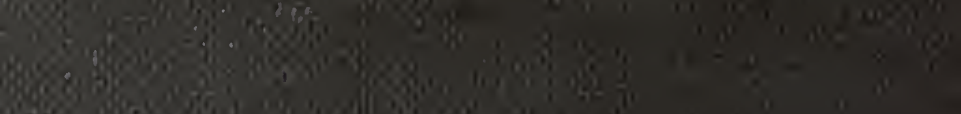

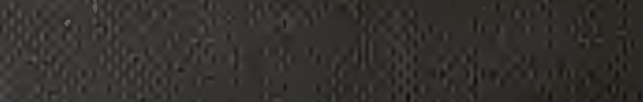

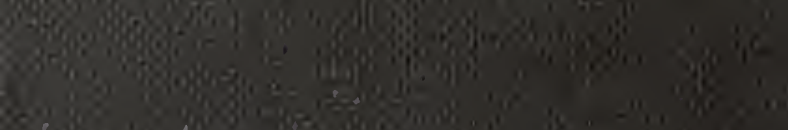

Sogn in?

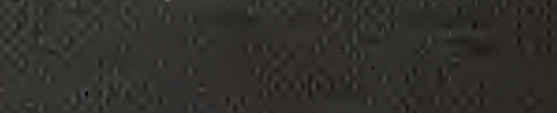

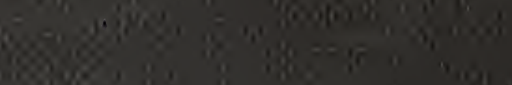
$86=306$

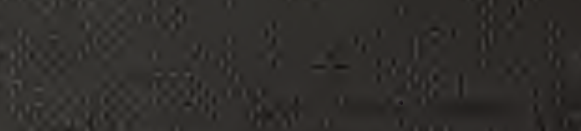

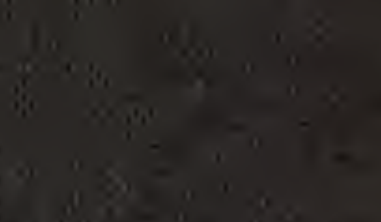
woris?

osioge

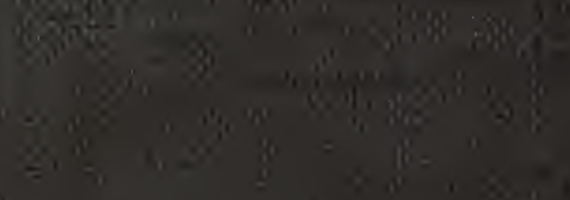

$$
30
$$
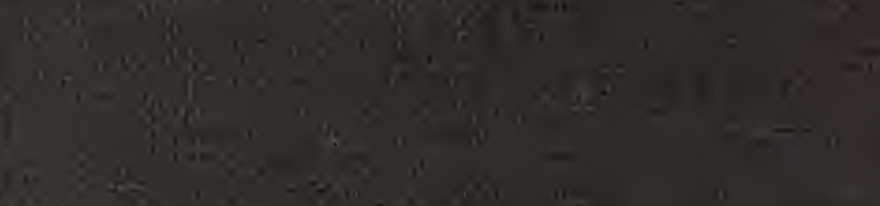

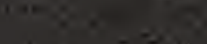

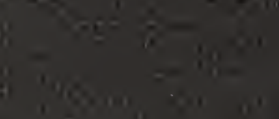

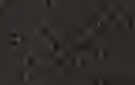

$-115$

$\frac{30}{10}=$

15

$8=x ;=\div$

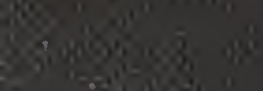

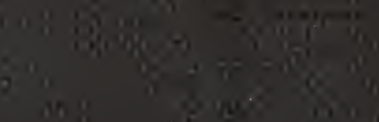

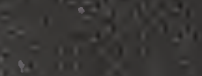

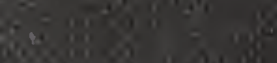

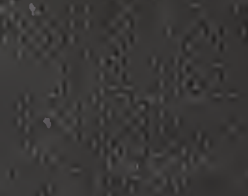

